\title{
DINÂMICA POPULACIONAL DE FUNGOS MICORRIZZICOS ARBUSCULARES NO AGROSSISTEMA CAFEEIRO E ADUBAÇÃO VERDE COM LEGUMINOSAS
}

\author{
ARNALDO COLOZZI FILHO \\ Engenheiro Agrônomo
}

Orientadora: Prof ${ }^{a}$ Dr $^{a}$ ELKE JURANDY BRAN NOGUEIRA CARDOSO

Tese apresentada à Escola Superior de Agricultura "Luiz de Queiroz", Universidade de São Paulo, para obtenção do título de Doutor em Agronomia, Área de Concentração: Solos e Nutrição de Plantas.

PIRACICABA

Estado de São Paulo - Brasil

Janciro - 1999 


\section{DINÂMICA POPULACIONAL DE FUNGOS MICORRÍZICOS ARBUSCULARES NO AGROSSISTEMA CAFEEIRO E ADUBAÇÃO VERDE COM LEGUMINOSAS}

\section{ERRATA}

Página 37 - na tabela 2, na sequência de letras relativas ao teste de médias aplicado no número de esporos observados no cultivo intercalar, para a Crotalaria breviflora, avaliada em jul./97, onde se lê $A b a$ leia-se $A a$. Para o Amendoim cavalo, avaliado em jun./96, em vez de $A b b$ leia-se $A c$. Para o Caupi, avaliado em Fev./97, onde se lê $A b a$ leia-se $A a$. Também para o controle, avaliado em Jul./97, substitua-se $A c d$ por $B c d$.

Página 38 - Na $5^{a}$ linha do parágrafo inicial, onde se lê Fev./96, leia-se Fev./97.

Página $39-\mathrm{Na} 4^{\mathrm{a}}$ linha do $3^{\circ}$ parágrafo, onde se lê conforme discutido no capítulo 3 , leia-se dados ñ̃o apresentados.

Página 48 - Na $2^{\mathrm{a}}$ linha do $2^{\circ}$ parágrafo, onde se lê Fev./96 leia-se Fev./97. 
Este trabalho é dedicado às minhas queridas esposa e filhas, que durante tantos momentos de ausência souberam me entender e encorajar, acreditando sempre que estávamos construindo um futuro melhor. 
Para ser grande sê inteiro.

Nada teu exagera ou exclui.

Põe quanto és no mínimo que fazes. Assim como a lua, que em todo lago brilha porque alta vive.

"Fernando Pessoa" 


\section{AGRADECIMENTOS}

A amizade e a colaboração desinteressada de muitas pessoas, algumas conhecidas e outras que felizmente pude conhecer, foram responsáveis por grande parte do sucesso deste trabalho. A todos eles faço os meus sinceros agradecimentos.

À Profa Dra Elke Jurandy Bran Nogueira Cardoso, pela orientação, confiança e também pelas oportunidades de enriquecimento profissional que me proporcionou.

À Profa Dra Maria Helena Pelegrinelli Fungaro, do Centro de Ciências Biológicas da Universidade Estadual de Londrina-PR, pelo treinamento intensivo em biologia molecular e pela amizade.

À Profa Dra Sandra Maria Gomes da Costa, do Centro de Ciências Biológicas da Universidade Estadual de Maringá-PR, pela identificação dos fungos micorrízicos. Ao Prof. Dr. Márcio Lambais, pelo apoio e amizade.

Aos colegas da área de solos do IAPAR, pela amizade e apoio.

À Dra Mariângela Hungria e funcionários do laboratório de microbiologia da EmbrapaSoja Londrina, pela cessão do laboratório e equipamentos na fase inicial do trabalho.

Aos colegas Oswaldo Machinesk, Aresmundinei Dias, Clarice Correia André e Maria Aparecida Mattos Bonfim, funcionários do laboratório de microbiologia do solo do IAPAR, pela incansável ajuda no manuseio dos fungos e raízes do campo.

Aos colegas Denise Lourdes Colombo Mescolotti e Luís Fernando Baldesin. do laboratório de microbiologia do solo da ESALQ, pelo apoio e amizade Ao grande amigo Marco Antonio Nogueira, pela incansável solicitude e amizade. A todos os colegas de curso que, com a convivência e comunhão do dia a dia, sempre nos ensinam algo de bom que nos ajuda a viver.

Ao IAPAR, ESALQ, CNPq e Capes, pela oportunidade. 


\section{APRESENTAÇÃO}

A presente Tese foi redigida em "Forma de Publicação", de acordo com as Normas para Elaboração de Dissertações e Teses da ESALQ/USP (1997) e é composta pelos seguintes trabalhos científicos:

1. Micorrizas arbusculares no agrossistema cafeeiro e adubação verde com leguminosas.

2. Metodologia simplificada para isolamento de DNA genômico de um único esporo de fungos micorrízicos arbusculares.

3. Ocorrência de fungos micorrízicos arbusculares em cafeeiro (Coffea arabica L.) cultivado com Crotalaria breviflora na entrelinha e sua deteç̧ão em raízes através da PCR.

Antecedendo a apresentação dos referidos trabalhos encontra-se uma Introdução e uma Revisão de Literatura de caráter geral. 
SUMÁRIO

Página

RESUMO.

viii

SUMMARY

1 INTRODUÇÃO............................................................................................ 1

2 REVISÃO DE LITERATURA............................................................ 4

2.1 A micorrização e as populações de fungos MA nativas................................ 5

2.2 Micorrizas no cafeeiro...................................................................................... 14

2.3 As práticas de cultivo e a micorrização..................................................... 17

2.4 Técnicas moleculares e a identificação dos fungos MA................................ 22

2.4.1 DNA ribossômico (rDNA).................................................................................... 23

2.4.2 PCR (reação em cadeia da polimerase)...................................................... 25

2.4.3 RAPD (polimorfismo da amplificação aleató ria do DNA)..................... 26

2.4.4 Análises de isoenzimas............................................................................ 27

3 MICORRIZAS ARBUSCULARES NO AGROSSISTEMA CAFEEIRO E ADUBAÇÃO VERDE COM LEGUMINOSAS........................................ 30

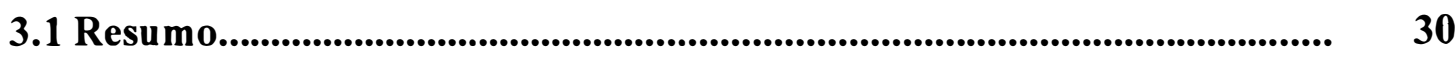

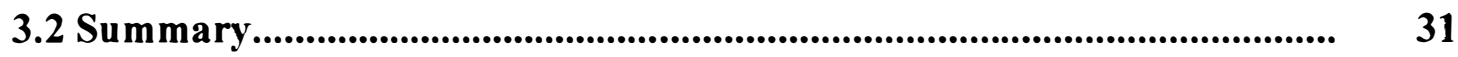

3.3 Introdução............................................................................................................ 32

3.4 Material e Métodos.................................................................................. 33

3.4.1 Cam po............................................................................................................... 33

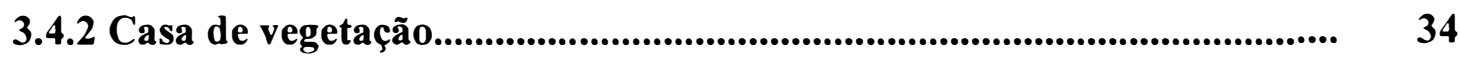

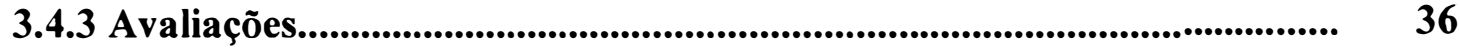

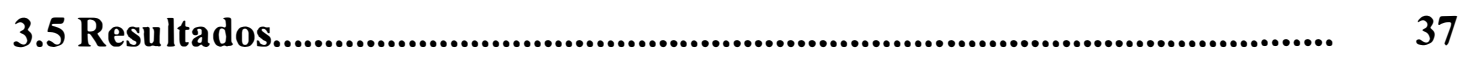

3.6 Discussão............................................................................................................ 46

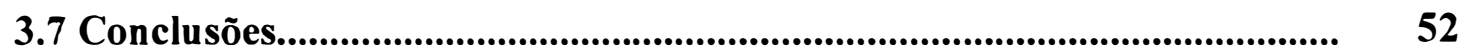

4 METODOLOGIA SIMPLIFICADA PARA ISOLAMENTO DE DNA GENÔMICO DE UM ÚNICO ESPORO DE FUNGOS MICORRÍZICOS ARBUSCULARES...................................................... 53

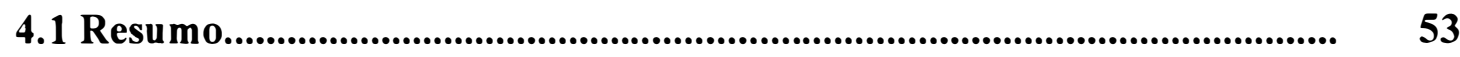


4.2 Summary ................................................................................................................ 54

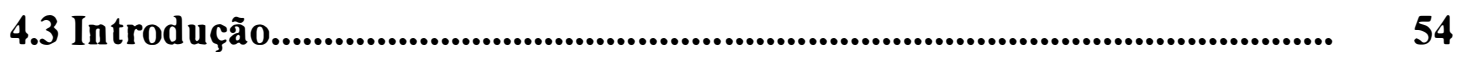

4.4 Material e Métodos.................................................................................. 57

4.4.1 Os esporos de fungos MA................................................................................... 57

4.4.2 Extração, amplificação e sequenciamento .............................................. 58

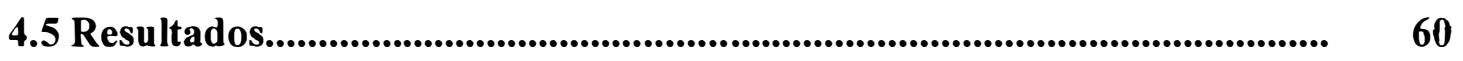

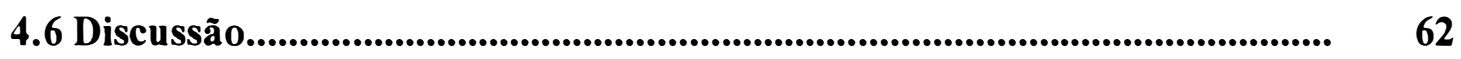

4.7 Conclusões................................................................................................... 65

5 OCORRÊNCIA DE FUNGOS MICORRÍZICOS ARBUSCULARES EM CAFEEIRO (COFFEA ARABICA L.) CULTIVADO COM CROTALARIA BREVIFLORA NA ENTRELINHA E SUA DETECÇÃO EM RAÍZES ATRAVÉS DA PCR ........................................ 66

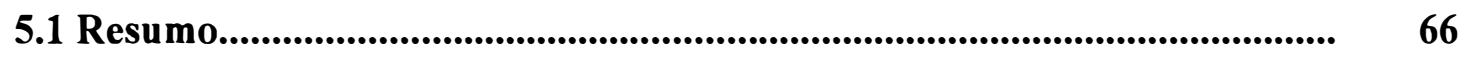

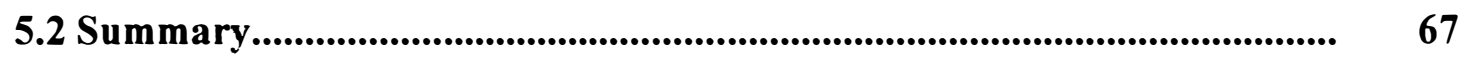

5.3 Introd ụ̧ão................................................................................................................. 68

5.4 Material e Métodos.................................................................................... 70

5.4.1 Esporos de fungos MA....................................................................................... 71

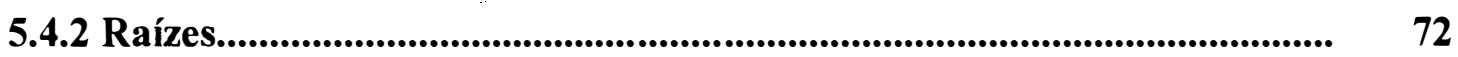

5.4.3 PCR de DNA de esporos e raizes.................................................................. 73

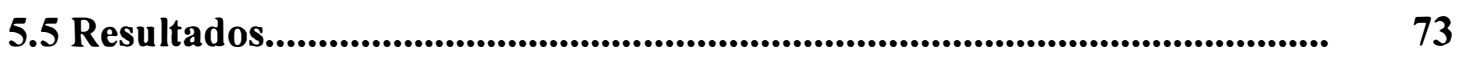

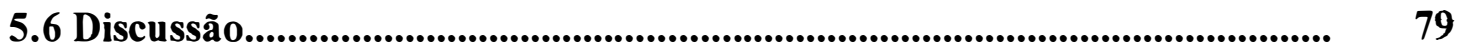

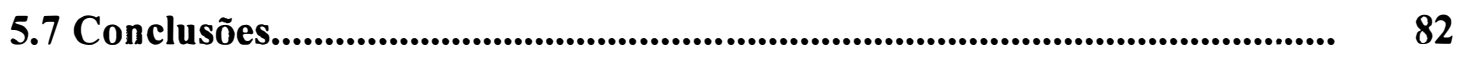

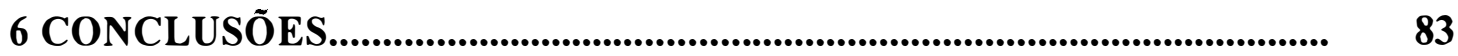

REFERÊNCIAS BIBLIOGRÁFICAS............................................................ 85 


\title{
DINÂMICA POPULACIONAL DE FUNGOS MICORRÍZICOS ARBUSCULARES NO AGROSSISTEMA CAFEEIRO E ADUBAÇÃO VERDE COM LEGUMINOSAS
}

\author{
Autor: ARNALDO COLOZZI FILHO \\ Orientadora: $\operatorname{Prof}^{\mathrm{a}} \operatorname{Dr}^{\mathrm{a}}$ ELKE JURANDY BRAN NOGUEIRA CARDOSO
}

\section{RESUMO}

Avaliou-se o efeito do cultivo intercalar de leguminosas de verão para adubação verde do cafeeiro (Coffea arabica L.), sobre a ocorrência e esporulação de fungos micorrízicos arbusculares (MA) no solo e a micorrização. Amostras de solo rizosférico e raízes foram coletadas no período entre junho de 1996 e julho de 1997, em três épocas, em um experimento de longa duração, conduzido a campo pelo Instituto Agronômico do Paraná- IAPAR, no município de Mirasselva, PR. O experimento está instalado em uma área de latossolo vermelho escuro distrófico (LEd) onde, nas linhas principais, se cultiva o cafeeiro 'Catuaí Amarelo' e nas entrelinhas as leguminosas Leucena (Leucaena leucocephala), Crotalaria spectabilis, C. breviflora. Mucuna cinzenta (Stizolobium pruriens), Mucuna anã (Stizolobium deeringianum), Amendoim cavalo (Arachis hipogeae) e Caupi (Vigna unguiculata) para fins de adubação verde. O delineamento experimental é de blocos ao acaso, com três repetições. Determinou-se a diversidade de espécies através da identificação morfológica dos esporos. a freqüência de ocorrência através da contagem direta de esporos no solo e a colonização radicular pelo método da placa quadriculada usando raízes coradas. Também foram conduzidos bioensaios em casa de vegetação, para estudar a composição das populações de fungos MA que efetivamente colonizavam as raízes do cafeeiro a campo. Com o mesmo objetivo 
utilizaram-se técnicas moleculares baseadas na amplificação de fragmentos de DNA através da PCR (Polimerase chain reaction), extraídos de esporos coletados na rizosfera e de raízes colonizadas coletadas a campo.

O cultivo de leguminosas na entrelinha de plantio do cafeeiro aumentou a diversidade de espécies e o número de esporos de fungos MA na rizosfera do cafeeiro. Cafeeiro cultivado com Crotalaria breviflora mostrou-se altamente micorrizado, com maior diversidade de espécies e número de esporos de fungos MA no solo, em todas as épocas avaliadas. Entretanto, parte da diversidade de fungos presentes na rizosfera do cafeeiro não foi recuperada na rizosfera de milho (Zea mays L.) e sorgo (Sorghum bicolor $\mathrm{L}$.) quando se utilizaram raízes colonizadas de cafeeiro como inóculo, sugerindo que alguns dos fungos MA observados na rizosfera do cafeeiro podem ser provenientes das raízes das leguminosas que crescem próximas, mas não estão efetivamente em simbiose com o cafeeiro. Através da PCR e usando primers de ITS (Internal transcribed spacer) foi possível comparar bandas obtidas a partir de DNA extraído de esporos coletados na rizosfera com bandas obtidas a partir de DNA extraído de raízes colonizadas. Bandas características de Scutellospora gilmorei não foram encontradas nas raízes de cafeeiro colonizadas, confirmando os resultados obtidos através de bioensaios em casa de vegetação. Estes resultados sugerem a ocorrência de relações preferenciais entre fungos e hospedeiros, que podem determinar o estabelecimento e a eficiência da simbiose micorrízica ou mesmo a exclusão de algumas espécies do sistema radicular da planta.

Neste trabalho foi possível, também, desenvolver um método para isolamento de DNA genômico de diferentes gêneros de fungos MA. Com este método, a partir de um único esporo de fungos MA foi possível obter, de maneira simples e rápida. DNA de qualidade e em quantidade suficiente para a PCR. 


\title{
POPULACIONAL DINAMIC OF ARBUSCULAR MYCORRHIZAL FUNGI IN AN AGROSYSTEM WITH COFFEE PLANTS INTERCROPPED WITH LEGUME AS GREEN MANURE
}

\author{
Author: ARNALDO COLOZZI FILHO \\ Adviser: Prof ${ }^{a}$ Dr $^{a}$ ELKE JURANDY BRAN NOGUEIRA CARDOSO
}

\section{SUMMARY}

Sporulation and occurrence of arbuscular mycorrhizal fungi (AM) were evaluated on coffee trees (Coffea arabica L.) intercropped with legume for green manure. Samples of rhizosphere soil and roots were collected at three times between July 1996 and July 1997, in a long term experiment located at the Instituto Agronômico do Paraná - IAPAR, at Mirasselva city, Paraná state. Brazil. The AM diversity was determined through the morphologic identification of spores, the AM occurrence frequency by the direct counting of spores in the soil and the root colonization evaluated with the grid-line method using stained roots. Bioassays were also conduced at the green-house. to study the AM composition inside the coffee roots from the field. With the same objective, molecular techniques based on the DNA fragment amplification by PCR (Polimerase chain reaction) were used. DNA of spores collected in the rhizosphere and from colonized roots collected at the field was extracted.

Legume intercropping increased the AM diversity and the inoculum potential in the coffee rhizosphere. Crotalaria breviflora showed a high mycorrhízal capacity, able to form symbiosis with several species of AM fungi, resulting in a greater AM diversity, spore number in the soil. at all evaluation periods. This effect was also observed in the 
coffee rhizosphere. However, part of the AM diversity in the coffee tree rhizosphere was not recovered in corn (Zea mays L.) and sorgum (Sorghum bicolor L.) rhizosphere when colonized coffee roots was used as inoculum, suggesting that some AM fungi observed in the coffee rhizosphere originated from the legume roots, but were indeed not in symbiosis with the coffee trees. Through PCR and using the combined primers of ITS (Internal transcribed spacer) 4 and 5 , it was possible to compare bands obtained from extracted DNA of spores collected in the rhizosphere with bands obtained from extracted DNA of colonized roots. Characteristic bands of Scutellospora gilmorei were not found in the coffee roots. 


\section{INTRODUÇÃO}

Muitas culturas formam associações simbióticas com fungos micorrízicos arbusculares MA. Estes fungos são Zygomicetos da ordem Glomales e freqüentemente são os mais abundantes fungos de solo (Gerdemann \& Nicolson, 1963). Formam um grupo diverso de aproximadamente 144 espécies descritas (Shenck \& Perez, 1987), mas, apesar de sua abundância no solo e dos efeitos positivos que causam sobre o desenvolvimento das plantas, pouco se sabe sobre sua ecologia. No Brasil, o trabalho pioneiro sobre ocorrência de micorrizas no cafeeiro, realizado por Cardoso (1978), mostrou a ocorrência natural destes fungos em mudas de cafeeiros produzidas em viveiros do estado de São Paulo. E a inoculação das mudas com espécies de fungos MA selecionadas mostrou-se eficiente em estimular o estabelecimento da simbiose no início do desenvolvimento das plantas (Colozzi Filho et al., 1985), proporcionando mudas sadias e mais resistentes ao estresse causado pelo transplantio para o campo. Entretanto. as espécies eficientes selecionadas, quando introduzidas via inoculação, têm dificuldade de permanecer no agrossistema (Balota \& Lopes, 1996b). Normalmente no campo se observa a ocorrência de espécies indígenas de baixa eficiência simbiótica (Balota \& Lopes. 1996a), possivelmente selecionadas pelo monocultivo continuado que, segundo Johnson et al. (1992), pode ser a causa da diminuição da diversidade e seleção de espécies menos eficientes. Portanto, a manutenção de populações de fungos MA diversificadas e ativas na rizosfera das plantas é importante para a sustentabilidade do agrossistema (Bethlenfalvay \& Linderman. 1992) O manejo do solo e das culturas parece ser a alternativa mais apropriada para manter ou aumentar a diversidade de espécies. o número de esporos no solo e o potencial de inóculo natural de fungos MA a campo. 
A eficiência dos fungos MA em aumentar o crescimento das plantas depende da inter-relação entre os fatores edáficos, a planta hospedeira e o fungo (Hall, 1988). Consequentemente, é necessário entender como os fungos $\mathrm{MA}$ e as plantas se relacionam em condições de campo e que fatores controlam suas populações nos agrossistemas (Abbott \& Robson, 1982). Diversos estudos têm examinado os efeitos de rotações de cultivos e pré-cultivos na colonização micorrízica e na produção de esporos (Sieverding \& Leihner, 1984; Dood et al., 1990; Johnson et al., 1992) mas, pouco se conhece dos efeitos destas práticas sobre a comunidade de fungos micorrízicos em cafeeiros a campo.

Em situações de campo, a avaliação de populações requer a identificação precisa das espécies presentes e a quantificação da densidade de propágulos e sua infectividade. Até o momento, bioensaios de vários tipos são a técnica mais comum utilizada para multiplicar fungos MA isolados do solo e avaliar sua infectividade. Estes ensaios têm a vantagem de incluir todos os propágulos micorrízicos infectivos presentes no solo, mas dão informações limitadas sobre a composição das espécies no solo. O isolamento de esporos e sua multiplicação em planta hospedeira são o principal meio para se conhecer as espécies presentes na rizosfera. Entretanto, através desta técnica não é possível determinar as espécies que estão efetivamente colonizando as raízes. A inoculação da planta hospedeira com raízes colonizadas pode ser um procedimento eficaz, mas é um processo trabalhoso e demorado e de eficiência não garantida.

Atualmente, os estudos de ecologia microbiana têm sido auxiliados pelo desenvolvimento e adaptação de técnicas comumente utilizadas em estudos de biologia molecular. Estas técnicas incluem o uso de anticorpos específicos, provas de DNA e reações específicas da polimerase em cadeia (PCR) com primers específicos para diferentes espécies, bem como perfil de lipídeos e isoenzimas. (Rosendahl \& Sen, 1992; Simon et al.. 1992; Bentivenga \& Morton, 1994. Clapp et al., 1995). Métodos baseados no DNA podem ser suficientemente precisos para distinguir diferentes isolados da mesma espécie. mas necessitam ainda de adaptações e estudos para serem rotineiramente utilizados em trabalhos com micorrizas. Um método rápido e preciso para a identificação de fungos MA presentes na rizosfera e nas raízes das plantas poderia 
contribuir para a seleção e o uso de técnicas de manejo do solo, plantas e fungos, visando aumentar o efeito biofertilizante das micorrizas nos agroecossistemas.

Neste trabalho, utilizando-se de métodos tradicionais de trabalho in-vivo no campo e em casa de vegetação e métodos moleculares baseados na análise de fragmentos de DNA amplificados através da PCR, estudou-se o efeito do cultivo intercalar do cafeeiro com leguminosas de verão para adubação verde, sobre a ocorrência de fungos MA e a micorrização do cafeeiro. 


\section{REVISÃO DE LITERATURA}

Micorrizas arbusculares são associações simbióticas mutualistas formadas entre os fungos da família Endogonaceae, Zigomicotina (Morton \& Benny, 1990) e raízes da maioria das plantas superiores, caracterizando-se pela penetração do micélio fúngico inter e intracelularmente, sem causar modificações morfológicas nas raízes. São de ocorrência generalizada, podendo-se afirmar que plantas não possuem raizes, mas sim micorrizas (Marx \& Brian, 1975). Segundo Silveira (1992), os principais benefỉcios desta simbiose para as plantas são a melhoria do estado nutricional da planta e melhor utilização e conservação dos nutrientes no sistema solo-planta; modificações fisiológicas e bioquímicas diversas como maior produção de substâncias de crescimento, maior taxa fotossintética, atividade enzimática, etc; melhoria na adequabilidade das plantas ao ecossistema e na capacidade inicial de adaptação de mudas transplantadas; redução nos efeitos provocadas por estresses de natureza biótica (pragas e doenças) ou abiótica (déficit hídrico, nutricional ou térmico).

Os efeito dos FMA para as plantas são atribuídos ao desenvolvimento do micélio no solo que estabelece pontes conectando as raízes com as partículas de solo circundantes, aumentando a ciclagem de nutrientes e sua aquisição pelas plantas. As hifas também produzem efeitos fĩsicos no solo, atuando sobre sua estruturação (Bethlenfalvay, 1992).

Do ponto de vista prático, os benefícios nutricionais são os de interesse imediato e mais promissores. Plantas micorrizadas têm seus requerimentos nutricionais reduzidos à metade ou até a $1 / 10$ quando comparadas com aquelas não micorrizadas (Siqueira \& Franco. 1988). Estes efeitos são mais acentuados para nutrientes que possuem baixa mobilidade no solo como $\mathrm{P}, \mathrm{Zn}$ e $\mathrm{Cu}$ para a maioria das plantas e $\mathrm{N}$ para as leguminosás. Neste caso, embora as micorrizas não possuam a habilidade de fixar $\mathrm{N}_{2}$ atmosférico, elas 
favorecem a nodulação e fixação biológica do $\mathrm{N}_{2}$, principalmente em condições subótimas de P (Pacovsky, 1989). O favorecimento na absorção de nutrientes pelas raizes resulta principalmente do aumento da área de superfície das raizes micorrizadas, que podem conter até $1,5 \mathrm{~m}$ de hifa em cada $\mathrm{cm}$ de raiz colonizada. As hifas se espalham no solo, e quando a difusão é limitante, podem representar aumentos de até 10 a 60 vezes na superfície e absorção do nutriente, respectivamente. Deste modo, a utilização dos nutrientes da solução do solo, mineralizado ou fornecido via fertilização, será aumentada e o requerimento de fertilizantes reduzido na mesma proporção (Silveira, 1992).

Os FMA têm uma significância chave nos sistemas solo-planta pois relacionamse a processos importantes para a sustentabilidade em solos disturbados ou áreas naturais (Barea \& Azcón-Aguillar, 1983). Bethlenfalvay \& Linderman (1992) citam os FMA como mediadores da troca de nutrientes no sistema solo-planta. Segundo estes autores, o micélio de FMA é atuante em uma estreita inter-relação de causa e efeito na troca de nutrientes minerais, compostos de $\mathrm{C}$, sinais entre a planta e a comunidade de microrganismos da rizosfera, sendo capazes de estabelecerem uma rede ligando os diferentes componentes do sistema solo planta. Portanto, o manejo dos FMA pode ser um caminho para se restabelecer a componente biológica do sistema solo-planta.

\subsection{A micorrização e as populações de fungos MA nativas}

Existem poucas informações sobre a biologia básica e a ecologia dos FMA. Embora já em 1963 tenham sido citados como abundantes fungos de solo (Gerdemann \& Nicolson. 1963), seu ciclo de vida completo permanece pouco entendido, principalmente pela dificuldade técnica de serem estudados. Estes fungos são simbiontes obrigatórios e portanto não se multiplicam na ausência de raízes vivas. Seu cultivo em meios artificiais até hoje não foi conseguido. Para crescer na raiz, no solo e se reproduzir, os FMA precisam estar em simbiose e receberem da planta os fotossintatos e fatores de crescimento de que necessitam (Silveira, 1992).

Os esporos são estruturas de multiplicação e disseminação dos fungos e têm grande capacidade de sobrevivência mesmo em condições extremas de estresse (Abbott \& Robson. 1991). Após prolongados períodos de estresse ou dispersão para um novo 
habitat, germinam no solo, emitindo uma ou mais hifas que, sob condições ambientais adequadas, podem se expandir, se alongar e aderir às raízes. Após a adesão, a hifa penetra intercelularmente nas raízes, dando início à colonização, formando vesículas intra ou intercelularmente e arbúsculos intracelularmente. A seqüência de eventos: extensão linear da hifa, desenvolvimento dos arbúsculos, senescência e formação de vesículas são um processo constante e diretamente ligado à taxa de crescimento das raízes e ao estádio fisiológico das plantas (Allen, 1992). A rede de hifas ou micélio se expande dentro e fora das raízes, mas seu desenvolvimento é regulado pela interação fungo-hospedeiro e pelo ambiente. Desequilíbrios nesta relação, ocasionados por fatores bióticos (doenças nas plantas, hiperparasitismo de FMA) ou abióticos (fertilização ou preparo de solo) podem afetar a colonização radicular, reduzindo-a e diminuindo o efeito da micorrização, ou aumentando-a e acentuando o dreno de fotossintatos que pode limitar a produção de biomassa pela planta (Siqueira \& Franco, 1988).

Ao mesmo tempo que o fungo se estabelece e se desenvolve nas raízes, ele produz extenso micélio extraradicular que se ramifica e cresce através do solo, podendo chegar a distâncias médias de até $10 \mathrm{~cm}$, embora valores de $100 \mathrm{~cm}$ (Sieverding, 1991) e até metros (Varma, 1995) tenham sido relatados. Através do micélio externo, o contato das raízes com o solo circundante é consideravelmente aumentado, e o volume de solo explorado pelas raizes micorrizadas pode aumentar de 5 a 200 vezes, dependendo da compatibilidade entre os simbiontes e as condições edáficas. A rede de hifas que os FMA formam no solo podem conectar diferentes plantas e transferir nutrientes entre elas, permitindo assim que espécies pouco competitivas possam coexistir (Newman. 1988). Esta hipótese levanta novos questionamentos sobre o papel dos FMA e sua importância na sustentabilidade dos ecoagrossistemas. As hifas externas e fragmentos de raízes colonizadas podem também atuar como propágulos de FMA e serem tão infectivos quanto os esporos (Ingleby et al. 1997). Segundo Tommerup \& Abbott (1981), fragmentos de hifas podem permanecer viáveis no solo por até seis meses, inclusive em solos ressecados. Grandes variações na distribuição de hifas também podem ocorrer devido aos fatores do solo (Abbott \& Robson, 1985), o que geralmente é atribuído a questões adaptativas da espécie frente às condições edáficas a que é 
submetida (Abbott \& Robson, 1984).A falta de informações sobre o micélio externo geralmente é atribuída à dificuldade de determinar a colonização do solo (Graham et al., 1982; Abbott et al., 1984) e os resultados encontrados são muitas vezes controvertidos, devido aos diversos métodos empregados na sua avaliação (Graham et al., 1982; Pacovsky \& Bethlenfalvay, 1982).

Os esporos são produzidos após a colonização radicular, dentro e/ou fora das raízes, na região da rizosfera. O conhecimento sobre sua dinâmica de formação é limitado. Estudos sugerem que são principalmente distribuídos nas raízes próximas à superficie do solo, onde há maior concentração de desenvolvimento radicular, maior concentração de nutrientes lábeis e também maior atividade de matéria orgânica (Abbott \& Robson, 1991; Ingleby et al., 1997). A esporulação no solo é extremamente variada, dependendo da espécie fúngica e do ecoagrossistema.

A maior parte das estruturas de propagação fúngica ocorre entre a profundidade de $20 \mathrm{~cm}$ e a superfície do solo, diminuindo com a profundidade (Abbott \& Robson, 1991). Os esporos podem ser transportados para partes mais profundas do solo pela água, ou serem carregados por pequenos animais do solo (ex: artrópodes), porém, em profundidades entre 50 a $60 \mathrm{~cm}$, o número de esporos é pequeno (Sieverding, 1991). Esta distribuição de propágulos (esporos e hifas) no perfil do solo relaciona-se principalmente com o desenvolvimento do sistema radicular das plantas e com a oxigenação do ambiente edáfico. Em maiores profundidades. a concentração radicular e de oxigênio diminem, diminuindo a ocorrência de micorrização. Segundo Janos (1995), isto é particularmente importante para solos argilosos tropicais. onde a micorrização tende a se desenvolver mais em superficie. A remoção ou perda da superficie do solo, causada pelo cultivo excessivo ou pelo preparo inadequado, diminuem o inóculo do solo por atuarem negativamente sobre os propágulos na superficie (Sieverding, 1991). Cuenca \& Lovera (1992) estudaram os efeitos da escavação e limpeza do solo para a construção de estradas na Venezuela e observaram que dois anos após a limpeza, os sítios perturbados tinham 13 esporos de FMA em 100g de solo contra aproximadamente 200 esporos em 100g de solo. observados na área ao lado, não perturbada. Os autores 
concluíram que a retirada dos propágulos retardou o estabelecimento de plantas nativas altamente dependentes da micorrização.

A retirada da cobertura vegetal e preparo do solo para plantio implica na desagregação do solo, exposição à luz solar e elevação de temperatura na sua superfície. Isto pode acarretar a fragmentação da rede de hifas e a exposição de hifas e esporos. Além disso, o preparo do solo ocasiona mudanças profundas no sistema edáfico, tais como mudanças no conteúdo de matéria orgânica, estrutura do solo, aeração, porosidade e percolação de água, que indiretamente atuam sobre as micorrizas (Janos, 1995). Entretanto, devido ao grande número de relações envolvidas, é difícil precisar o exato impacto destes fatores sobre o potencial de inóculo do solo, principalmente em situações de campo. Por exemplo, Sieverding (1991) sugere que o corte e as queimadas na agricultura têm poucos efeitos negativos sobre os propágulos de FMA, porque as altas temperaturas que atingem a superfície do solo não são suficientes para inviabilizá-los. Janos (1995) cita que a fertilização do solo pelas cinzas das queimadas pode aumentar a disponibilidade de nutrientes, o que atua negativamente sobre a colonização das espécies facultativas e reduz o inóculo do solo.

Os FMA não apresentam especificidade de hospedeiro (Mosse, 1975), entretanto a resposta do hospedeiro difere com a espécie fúngica (Siqueira et al.. 1986) e com isolados geográficos dentro da espécie (Bethlenfalvay et al., 1989). O sistema radicular pode ser colonizado simultaneamente por mais de uma espécie fúngica e o sucesso na ocupação depende da relação fungo-hospedeiro. Alguns FMA são mais agressivos em colonizar determinadas plantas. mas nem sempre são os melhores mutualistas quando comparados com fungos menos efetivos (Hetrick \& Wilson, 1991).

Sinais químicos trocados entre planta e fungo podem atuar como um gatilho para o reconhecimento e para iniciar a colonização das raizes pelas hifas (Piché et al., 1994). Flavonóides e outros compostos fenólicos podem estar envolvidos na comunicação fungo-hospedeiro (Giovannetti et al., 1993 e 1996). Giovannetti et al. (1994) demonstraram que as hifas de Glomus mosseae foram capazes de discriminar seus hospedeiros dentre todas as outras espécies de plantas não hospedeiras ou hospedeiras de outros tipos de fungos, através do processo de reconhecimento dirigido pela percepção 
dos sinais químicos derivados somente dos hospedeiros de FMA. Segundo Graham \& Eissenstat (1994), devido à falta de especificidade, os genes para a compatibilidade presumivelmente são homólogos entre os genótipos da planta e do fungo, estando envolvidos no reconhecimento planta-fungo, infecção fúngica e reação da planta e, principalmente, na morfologia e na função da associação micorrízica para a troca de carboidratos.

McGonigle \& Fitter (1990) coletaram amostras de raízes de arbustos e gramíneas que cresceram misturados, com o objetivo de distinguir a colonização de Glomus tenue dos outros fungos MA indígenas e observaram que, a gramínea Holcus lanatus foi predominantemente colonizada por G.tenue, enquanto que outras três espécies de plantas foram colonizadas principalmente por outras espécies de FMA, que não G.tenue. Os autores concluíram que os FMA no campo podem exibir certo grau de especificidade ecológica e que não existe especificidade absoluta entre as espécies de FMA e a planta hospedeira. Trufem (1990) e Trufem et al. (1994) investigaram a ocorrência de FMA na rizosfera de várias plantas em matas nativas e no litoral arenoso do Parque Estadual da Ilha do Cardoso, SP. e observaram preferências acentuadas entre os fungos MA e determinados hospedeiros, sugerindo também especificidade ecológica. McGonigle \& Fitter (1990) mostram resultados semelhantes e observam que, em situações de campo, o hospedeiro pode ser colonizado preferencialmente por um ou mais FMA.

Sieverding (1991) observou alta freqüência de ocorrência de Sclerocystis coremioides em Desmodium sp. e cita que este FMA somente se reproduz em Desmodium. O mesmo autor também cita que uma espécie de Glomus não identificada somente se multiplica no hospedeiro do qual foi isolado, mas não em leguminosas originárias do mesmo local. Segundo Sieverding (1991), a associação preferencial ocorre quando a planta e/ou as condições do ambiente são ótimas para uma ou poucas espécies da comunidade de fungos, que serão beneficiados com o aumento na capacidade competitiva da associação, conduzindo a mudanças na composição quantitativa da comunidade dos FMA. As espécies de FMA associadas preferencialmente, adquirem mais fotoassimilados do hospedeiro do que as outras, aumentando sua dominância no solo. Sanders et al. (1995) sugeriram que a colonização 
do hospedeiro por uma espécie de FMA que se desenvolve rapidamente no interior da raiz e posteriormente explora grande volume de solo para absorção de $\mathrm{P}$ disponível, será benéfica para a planta e, portanto, poderá ser preferencialmente selecionada pelo hospedeiro. No entanto, Abbott \& Gazey (1994) alertam para o fato de que a abundância de esporos de um certo FMA no solo pode não indicar a quantidade de raízes colonizadas por este fungo.

A substituição da vegetação nativa por plantas de interesse agronômico pode exercer pressão seletiva nas populações de FMA (Read, 1991). Johnson et al. (1992), observaram pressão de seleção de monoculturas de milho e soja sobre populações de FMA Segundo os autores. a mudança na população pode ser devido a preferência seletiva destas plantas por alguns membros da comunidade de FMA. Estes autores demonstraram também que as espécies que predominaram nestas culturas foram negativamente relacionadas com a produção. Johnson \& Pfleger (1992) afirmaram que não existe motivo para esperar que, dentro de um sistema, espécies dominantes de FMA sejam os mutualistas mais benéficos, porque a monocultura pode selecionar espécies de FMA que são mutualistas menos eficientes e estes fungos podem estar envolvidos no declínio da produção. Sieverding (1991) sugeriu que os fungos não eficientes são capazes de drenar carboidratos do hospedeiro em quantidade suficiente para aumentar o número de propágulos no solo.

Johnson et al. (1992) acreditam que pode existir entre os simbiontes um mecanismo de resposta positiva ou negativa, que influencia a estrutura da comunidade de plantas e dos FMA. Este mecanismo será positivo e estabilizará a comunidade de plantas, se as espécies de FMA que proliferarem no interior do hospedeiro forem mutualistas benéficos. O mecanismo será negativo e desestabilizará a comunidade de plantas se ocorrer a proliferação de fungos que apresentam comportamento parasita. Como conseqüência. espécies de FMA ineficientes podem aumentar em abundância. sendo desfavorável para as plantas hospedeiras ( Johnson et al., 1992). A ineficiência é resultado do custo de $\mathrm{C}$ para o hospedeiro colonizado que excede o benefício obtido com a colonização. Assim, os efeitos da associação serão negativos (Cooperbrand et al., 1994; Janos, 1995). 
O desenvolvimento das hifas nas raízes dos hospedeiros e a disponibilidade dos açúcares solúveis no seu exsudato significam um mecanismo para o controle das populações de FMA (Schwab et al., 1984). Foi sugerido por Johnson et al. (1992b) que este mecanismo pode envolver adaptações das plantas para exercerem controle sobre as populações de FMA e que podem selecionar os melhores mutualistas. Por outro lado, plantas e fungos podem estar engajados em uma corrida evolutiva: quando a fertilidade do solo for alta, as plantas podem alocar menos carbono para os exsudatos da raiz e talvez selecionar FMA que requeiram menos carboidratos.

Os FMA podem ser favorecidos na seleção pelo hospedeiro se possuírem capacidade para colonizar rapidamente as plantas, induzindo grandes e positivas respostas de crescimento e reprodução (Sanders et al., 1995). Por outro lado, plantas hospedeiras podem desenvolver mecanismos de resistência para excluir colonizações por espécies de FMA não eficientes, que causem significativos custos para o hospedeiro.

A formação da associação micorrizica e seu benefício é muito variável entre as espécies de planta porque elas exibem diferentes graus de dependência micorrízica. Segundo Gerdemann (1975), dependência micorrízica é o grau de dependência da planta ao fungo para um desenvolvimento normal, a um determinado nível de fertilidade do solo. Dentro deste conceito, segundo Siqueira \& Franco (1988) as plantas podem ser agrupadas em 1) micotróficas obrigatórias: quando dependem da simbiose para absorção de nutrientes do solo e sobrevivência, exibindo altas taxas de colonização, sendo beneficiadas pela simbiose independentemente da concentração de $\mathrm{P}$ disponível no solo; 2) micotróficas facultativas: quando podem crescer na ausência do simbionte, sendo que apresentam baixas taxas de colonização radicular e somente se beneficiam da simbiose em solo com baixa concentração de $P$; 3 ) não micotróficas: quando não dependem e não se beneficiam da micorrização e, geralmente, não apresentam colonização.

As espécies micotróficas obrigatórias não podem sobreviver e atingir a maturidade reprodutiva na ausência de micorrizas, no mesmo nível de fertilidade encontrado em seu habitat natural. Estas espécies somente crescem sem micorrizas quando intensamente fertilizadas. Segundo Janos (1995), algumas árvores tropicais são incapazes de crescerem sem micorrizas sob qualquer regime mineral. Plantas 
micotróficas facultativas podem atingir a maturidade reprodutiva na ausência dos FMA em solos férteis, mas por outro lado podem apresentar abundante colonização em solos de baixa fertilidade (Janos, 1980).

No solo, as plantas podem ser funcionalmente interconectadas através de micélio de fungos MA (Newman, 1988; Sanders et al., 1995). Segundo o mesmo autor, estas conexões servem para exportar fotoassimilados entre as espécies, reduzindo situações desfavoráveis ao desenvolvimento, possibilitando sua coexistência e maior diversidade florística. Segundo Miller (1987), a intensidade de ocorrência destas conexões entre plantas no campo deve ser muito freqüente, visto que, em algumas espécies de plantas, mais de $80 \mathrm{~cm}$ de hifas do fungo por centímetro de raiz infectada foi observado. A conexão entre plantas via hifas dos FMA, a níveis intra e interespecíficos, sugere que o entendimento dos efeitos entre plantas vizinhas abaixo do solo pode ser necessário para explicar efeitos que ocorrem acima.

Atualmente são conhecidas aproximadamente 150 espécies de FMA, distribuídas em seis gêneros que são: Acaulospora, Entrophospora, Gigaspora, Glomus, Sclerocystis e Scutellospora (Morton \& Beny, 1990). As populações de FMA nativas variam na composição de espécies, porque sua ocorrência é determinada pela vegetação e pelo ambiente (Johnson et al., 1992). A diversidade biológica das populações nativas de FMA em ecossistemas não alterados varia em torno de aproximadamente 25 espécies. Em agrossistemas a diversidade diminui, variando de 5 a 15 espécies (Sieverding, 1991). A menor diversidade observada quando sistemas naturais são cultivados é atribuída a diminuição na diversidade de plantas (Siqueira et al.. 1989; Sieverding, 1991). Ecossistemas naturais mantém uma vegetação variada que diminui muito em agrossistemas intensivamente manejados. Monoculturas. por exemplo, mantêm apenas uma espécie vegetal por área, com eventuais invasoras não controladas, apresentando menor diversidade de FMA.

Os FMA também apresentam padrões de ocorrência diferenciados. Segundo Trufem \& Bononi (1985), existem espécies que ocorrem na maioria dos hospedeiros durante todo o ano; outras que ocorrem em grande densidade no solo mas são restritas a certos hospedeiros e épocas do ano: espécies de baixa densidade populacional mas sem 
restrições de hospedeiros ou épocas do ano e ainda espécies com baixa densidade populacional e hospedeiros restritos, além de ocorrência restrita a algumas épocas do ano.

As populações nativas, de uma maneira geral, refletem as grandes variações na ocorrência, efetividade e agressividade que caracterizam cada um dos FMA que as compõem e portanto apresentam variações na sua eficiência simbiótica (Paula et al., 1988). Devido a essas variações, em situações de campo, é desejável a manutenção ou obtenção de uma população de FMA diversificada, para que se aumentem as chances de que combinações eficientes entre fungo e hospedeiro possam ocorrer naquele ambiente. Entretanto, simplesmente a grande diversidade de espécies não garante a eficiência dos FMA. Sieverding, (1991) observa que menor diversidade pode resultar em eficiência simbiótica maior, desde que as espécies sejam mutualistas eficientes e tenham elevada capacidade competitiva na rizosfera.

No estudo do manejo das populações de FMA nativas, a caracterização das espécies e sua dinâmica de ocorrência são tão importantes quanto a determinação do potencial de inóculo e a colonização radicular, para o entendimento de seu comportamento no solo e a determinação da sua eficiência simbiótica (Bethlenfalvay \& Linderman. 1992).

A identificação dos FMA dentro do tecido do hospedeiro é extremamente importante para estudos ecológicos e de determinação de eficiência simbiótica de fungos em comunidade, entretanto, é difïcil e nenhum método de identificação morfológica foi satisfatoriamente desenvolvido (Miller et al., 1994). Segundo Abbott \& Gazey (1994), a morfologia dos FMA dentro da raiz pode sofrer mudanças dependendo do hospedeiro, da idade das raízes. da disponibilidade de $\mathrm{P}$ e do habitat, o que dificulta ainda mais a identificação, baseando-se na morfologia das hifas e estruturas produzidas (células auxiliares. vesículas, etc). Por isso. o desenvolvimento ou adaptação de métodos baseados no DNA podem contribuir para a identificação de fungos MA internamente às raízes.

A maneira mais freqüente de se estudarem as populações de FMA tem sido a determinação quantitativa (contagem direta) e qualitativa (identificação) dos esporos 
extraídos do solo. Os métodos para determinações quantitativas foram recentemente compilados por Colozzi Filho \& Balota (1994). Entretanto, o potencial de inóculo natural, que é a capacidade dos FMA nativos infectarem e colonizarem as raízes, nem sempre é explicado pelo número total de esporos no solo, devido principalmente a outras fontes de inóculo como micélio fúngico e fragmentos de raízes colonizadas (Abbott \& Robson, 1991). A presença e/ou abundância de determinados esporos de FMA no solo são indicativos de que esta espécie é ativa no sistema, capaz de colonizar e se multiplicar nas raízes da planta hospedeira, entretanto, para uma avaliação mais precisa da infectividade e eficiência da população de FMA nativa, é necessário considerar outros parâmetros além de esporulação no solo e colonização radicular, tais como o comprimento de hifas no solo e o potencial infectivo avaliado através de bio-ensaios (Sieverding, 1991).

Portanto, a presença de cada espécie nas populações de FMA nativos é resultado de suas interações com o solo, com a planta hospedeira, com outros FMA e a biota em geral e pode influir no potencial de infectividade natural do solo, na colonização radicular e na eficiência simbiótica. No estudo do manejo das populações de FMA nativos os fatores de solo, planta e fungo, componentes do sistema micorrízico, precisam ser considerados.

\subsection{Micorrizas no cafeeiro}

As micorrizas são de ocorrência generalizada no cafeeiro, sendo observadas naturalmente desde a produção de mudas em viveiros (Cardoso, 1978), até em plantas adultas no campo (Lopes et al.. 1983a). A simbiose micorrizica é particularmente importante para o cafeeiro porque estas plantas apresentam elevada dependência à micorrização na fase de mudas (Siqueira \& Colozzi Filho. 1986) e no campo. a manutenção de uma população de fungos MA diversificada pode eliminar os efeitos negativos do monocultivo sobre a seleção de espécies (Johnson et al.. 1992). que normalmente selecionam espécies mas adaptadas ao meio mas geralmente menos eficientes em promover os benefícios da micorrização. No campo, as espécies de FMA eficientes não são de ocorrência comum, possivelmente por não se adaptarem às 
condições edafoclimáticas (Lopes et al., 1983a). Entretanto, em cultivos de cafeeiro é naturalmente encontrada grande diversidade de espécies (Oliveira et al., 1990). Segundo Saggin Júnior \& Siqueira (1996), na rizosfera do cafeeiro já foram identificadas 45 espécies de Glomales, sendo 12 de Acaulospora, 17 de Glomus, 6 de Scutellospora, 4 de Gigaspora, 4 de Sclerocystis e duas de Entrophospora. Entretanto, a frequência de ocorrência é maior para espécies do gênero Acaulospora, seguido de Glomus. Segundo os autores, a menor freqüência de ocorrência foi observada para espécies do gênero Gigaspora Fernandes (1987) cita A.scrobiculata, A.morrowiae e A.mellea como as espécies dominantes em cafeeiros do Sul de Minas Gerais, com índice de ocorrência maior de $50 \%$. Neste mesmo estudo os autores relatam a ocorrência de baixa densidade relativa de esporos de Gi.margarita e G.etunicatum nas populações de fungos nativos. Estas espécies, principalmente Gi.margarita, tem sido citadas como eficientes em aumentar o crescimento de mudas de cafeeiro (Colozzi Filho et al. 1985; Antunes et al., 1988). Balota \& Lopes (1996a), estudando a persistência de Gi.margarita no solo após seis anos da inoculação e plantio das mudas inoculadas, observaram que esta espécie ainda se encontrava presente na área e influenciava a composição da população de fungos nativos. Segundo o autor, a competição por fotossintatos ou mesmo por espaço na raiz influencia a composição da comunidde de fungos nativos no solo. Além disso. espécies menos sensiveis a fatores edáficos supressivos, como acidez, metais tóxicos e hiperparasitas são favorecidas e podem predominar na rizosfera. Segundo Saggin Júnior \& Siqueira (1996), é difícil correlacionar características gerais de solo com ocorrência de espécies. número de esporos e colonização micorrízica. Entretanto, os autores citam a existência de tendências como o favorecimento sobre a ocorrência de A.morrowiae e E.colombiana e o efeito negativo sobre A.scrobiculata causado pela elevação na matéria orgânica do solo. Em relação ao pH, os autores citam maior ocorrência de A.morrowiae, A.mellea e E.colombiana em pH baixo e A.scrobiculata e G.etunicatum em $\mathrm{pH}$ mais elevado.

A esporulação no solo também é bastante variada e depende do fungo, da planta. de fatores de solo e da sazonalidade. Balota \& Lopes (1996a), estudando a micorrização 
em cafeeiros adultos em São Paulo, observaram efeito significativo positivo da adubação fosfatada com fosfato natural sobre a esporulação dos fungos nativos no solo. Os autores atribuem este efeito ao melhor aproveitamento do fosfato natural pelo fungo para a produção de esporos. Neste mesmo estudo observou-se esporulação crescente a partir de marco, atingindo o máximo em outubro, sendo este efeito associado a variações na temperatura e precipitação pluvial (Balota \& Lopes, 1996b). Além de fatores de solo e planta, a esporulação no solo pode ser afetada negativamente pela presença de predadores de esporos que crescem na rizosfera (Ross \& Daniel, 1982) mas não existem dados observados especificamente no cafeeiro a campo.

Em cafeeiros adultos, em condições de campo, a colonização micorrizica apresenta valores bastante variados. Nos diversos trabalhos que citam dados de colonização a campo podem ser observados valores que variam de $4 \%$, conforme Lopes et al. (1983a) a até valores próximos de $80 \%$, conforme relatado por Oliveira (1988). É evidente que uma das causas de variações tão grandes é inerente às condições de obtenção dos dados, que são diferentes. Entretanto, até no mesmo experimento, Saggin Júnior \& Siqueira (1996) citam que em situações de campo é difīcil correlacionar fatores edáficos com colonização radicular porque existe um grande número de complexas interações envolvidas. Entretanto, algumas tendências são observadas como, por exemplo, aquelas citadas por Fernandes \& Siqueira, (1989) que relatam que a adubação fosfatada do cafeeiro pode causar uma redução na colonização a campo ou exercer nenhuma influencia, dependendo da quantidade de $\mathrm{P}$ utilizada, freqüência de aplicação e nível original de $\mathrm{P}$ no solo. Calagem, idade da lavoura. variação sazonal e local também influenciam a colonização. Segundo Siqueira et al. (1990) a calagem favorece a colonização por eliminar fatores fungistáticos que atuam sobre a germinação de esporos no solo, além de atuar sobre a composição das populações de fungos MA. Segundo Saggin Júnior \& Siqueira (1996) a idade da lavoura pode afetar positiva ou negativamente a colonização radicular, estando este efeito associado à sustentabilidade da lavoura. Os autores comentam dados de colonização observados em lavouras adultas na Colômbia e em São Paulo. Na Colômbia, o cafeeiro adulto apresentou colonização 
maior, podendo tal fato estar relacionado ao sombreamento das lavouras. Este manejo estaria favorecendo a colonização das plantas por fungos MA e promovendo maior sustentabilidade do agrossistema cafeeiro em relação ao cultivo convencional praticado em São Paulo.

As relações da colonização micorrízica a campo com as características edáficas são de difícil interpretação, mas a comparação de dados de diversos experimentos de campo mostra que ela está mais relacionada às diferenças na composição de espécies e na quantidade de fungos nativos do que nas características de solo (Saggin Júnior \& Siqueira, 1996). Portanto, o entendimento destas relações a campo depende de estudos específicos que envolvam o conhecimento das espécies nativas, sua freqüência de ocorrência e principalmente suas relações com o hospedeiro, dentro do próprio ambiente natural de cultivo e o manejo praticado na condução da lavoura.

\subsection{As práticas de cultivo e a micorrização}

As práticas de cultivo, além dos efeitos diretos sobre o solo, podem também alterar as populações microbianas e também os fungos micorrízicos. Harinikumar \& Bagyaraj (1988) observaram redução de $40 \%$ no número de propágulos de FMA em solos que ficaram uma estação sem cultivo e mostraram que a mostarda, espécie não micotrófica. reduziu significativamente o potencial de inóculo do solo. Os autores sugeriram que a reconstituição do potencial de inóculo para os níveis da cultura anterior à mostarda demoraria pelo menos dois cultivos, utilizando hospedeiros micotróficos.

Os benefícios da rotação para a produtividade das culturas são reconhecidos e têm sido bastante estudados. Entretanto, as razões exatas para os aumentos de produção não têm sido estabelecidas. Respostas variáveis para fertilização indicam que fatores ainda não determinados atuam no sistema. Micorrizas podem ser parte destes fatores e estarem envolvidas nos efeitos das rotações sobre a produtividade das culturas.

Em sistemas agrícolas sustentáveis. a escolha do sistema de rotação e das culturas a serem rotacionadas deve considerar seus efeitos sobre as populações de FMA nativas, com o objetivo de manejá-las obtendo assim maiores efeitos da micorrização (Bethlenfalvay \& Linderman, 1992). Rotações de culturas influenciam as populações de 
FMA nativas e a infectividade natural do solo (Johnson et al., 1992). Por exemplo, o uso em rotação de espécies vegetais não micorrízicas pode diminuir a infectividade do solo e atuar negativamente sobre a micorrização dos cultivos seguintes (Black \& Tinker, 1979). Períodos prolongados de pousio também podem diminuir a infectividade natural do solo. O cultivo de uma espécie não micorrízica, seguido de longo período de pousio, pode diminuir drásticamente o potencial infectivo natural do solo (Thompson, 1987). Portanto, a estratégia de escolha do tipo de rotação deve também ser direcionada para 0 manejo das populações de FMA nativos, considerando sempre a possibilidade de aumentar ou no mínimo manter a diversidade de FMA no agrossistema.

Efeitos estimulatórios de rotações no aumento da colonização ou produção de esporos tem sido relatados em diversas seqüências de cultivos. Por exemplo, Sieverding (1991) observou maior colonização de mandioca (Manihot esculenta) quando cultivada em rotação com amendoim cavalo (Arachis hypogeae) do que quando em monocultura. Baltruschat \& Dehne (1989) mostraram que o potencial de inóculo de FMA em solo sob quatro anos de rotação foi consideravelmente aumentado se comparado com o do solo sob monocultura de milho. O efeito estimulatório de gramíneas sobre a esporulação de alguns FMA tem sido relacionado a seu agressivo sistema radicular, entretanto, relações mais aprofundadas sobre a natureza deste estímulo e a composição da população de FMA estimulada têm sido pouco estudadas. Neste mesmo trabalho, observou-se menor diversidade de espécies de FMA nas rotações em que se cultivou milho.

Os cultivos podem selecionar espécies de FMA e modificar a composição de suas populações nativas (Trufem \& Bononi, 1985; Johnson et al.. 1992). A alternância no cultivo de espécies vegetais diferentes pode ser importante para a manutenção do equilíbrio biológico do solo, evitando, assim, a seleção de espécies microbianas promovida pelo monocultivo, ou cultivo sucessivo de plantas da mesma espécie.

Diversos trabalhos mostram que rotações de culturas atuam positivamente não somente sobre a micorrização, através do aumento no potencial de inóculo natural do solo. mas também sobre a diversidade de espécies de FMA (Johnson et al., 1991; Gomes-da-Costa, 1993). Gomes-da-Costa (1993), estudando soja e milho cultivados em monoculturas ou rotação observou mudanças quantitativas e qualitativas na comunidade 
de FMA relacionadas às plantas hospedeiras, aos sistemas de cultivo e à ocorrência de associações preferenciais. O maior número de esporos no solo foi observado em monocultura de milho em todas as épocas avaliadas. Scutellospora coralloides, $S$. calospora e $S$. heterogama foram observadas apenas na rizosfera de milho em monocultura, sendo eliminadas do solo quando a soja foi cultivada em rotação. Gigaspora ramisporophora, posteriormente reconfirmada como Gigaspora margarita (Gomes-da-Costa, comunicação pessoal), mostrou preferência pela soja cultivada em monocultura. Acaulospora longula não apresentou especificidade de hospedeiro, não sendo afetada pelo manejo. Entretanto, $A$. mellea multiplicou-se melhor em culturas de soja e a rotação permitiu sua melhor multiplicação em milho, num claro efeito da cultura antecessora. Portanto, estes dados mostram a complexidade e a importância das associações preferenciais entre FMA e seu hospedeiro e como o manejo pode influir na sua ocorrência. Estudos de Johnson et al. (1992) mostraram que as monoculturas, além de modificar a população de FMA nativos, podem selecionar fungos que não são bons mutualistas, diminuindo a eficiência das populações nativas. Este efeito pode ser minimizado pela rotação de culturas. A mudança na composição das populações de FMA nativas e na sua eficiência, ocasionada pelo cultivo contínuo, pode estar relacionada com o declínio na produção de monoculturas, conforme sugerido por Schenck \& Siqueira (1987) e mais tarde por Johnson et al. (1992).

O cultivo intercalar é uma prática de manejo que também pode alterar as populações de fungos MA nativos. Por cultivo intercalar entende-se o cultivo de uma espécie vegetal secundária, realizado simultaneamente entre a cultura principal. com objetivos de cobertura do solo, controle de pragas ou mesmo adubação verde. Pode ser orientado (nas entrelinhas de plantio para culturas anuais ou perenes) ou disperso, no caso de pastagens.

O estabelecimento das culturas secundárias provoca modificações no ambiente de cultivo e no solo, sendo capazes de alterar o crescimento das plantas e a produtividade das culturas (Johnson \& Pfleger .1992). As modificações no solo podem ser alterações químicas (variações de $\mathrm{pH}$ e disponibilidade de nutrientes) promovidas pelo maior aporte de matéria orgânica e pela exsudação radicular, modificações na 
concentração de $\mathrm{CO}_{2}$ e na capacidade de retenção de água do solo promovidas pela penetração das raízes e modificações na comunidade microbiana, tais como proliferação de bactérias fixadoras de $\mathrm{N}_{2}$ e alterações no potencial de inóculo natural e nas populações de FMA nativas (Hungria et al., 1994).

O cultivo intercalar de leguminosas entre culturas perenes para fins de adubação verde é bastante utilizado, devido à capacidade destas plantas de se associarem com bactérias e fixarem nitrogênio biológicamente. A eficiência da fixação biológica de nitrogênio nas leguminosas está associada à disponibilidade de $\mathrm{P}$ no solo e à absorção de $\mathrm{P}$ pelas plantas relacionadas à micorrização. A maioria das leguminosas é colonizada por FMA e por isso desenvolve-se bem e nodula em solos com baixos teores de P (Cardoso. 1985; Herrera et al., 1984). Portanto, as leguminosas são hospedeiros efetivos de FMA e podem atuar sobre sua diversidade e potencial de inóculo natural no solo.

Johnson \& Pfleger (1992) aumentaram a densidade de FMA e o crescimento de mudas de árvores para produção de madeira cultivando milheto (Pennisetum americanum) e sorgo (Sorghum bicolor) nas entrelinhas. Thomas (1988) aumentou o status micorrízico e diminuiu a incidência de podridão radicular em coqueiros, através do cultivo intercalar múltiplo de Pueraria phaseoloides, Mimosa invisa e Calopogonium muconoides na área. Existe ainda a possibilidade de que o cultivo intercalar promova a conecção de plantas via micélio extrarradicular de fungos MA, estabelecendo um fluxo de nutrientes entre as plantas (Graves et al., 1997). Este fluxo é de particular interesse nas associações de cultivos que envolvem leguminosas porque podem fornecer $\mathrm{N}$ fixado biológicamente para não leguminosas. Entretanto, esta possibilidade precisa ser analisada com cuidado, porque o fluxo de nurientes entre plantas via micélio de FMA tem sido citado como insuficiente para afetar o crescimento de plantas (Newman, 1988). Do mesmo modo que pode aumentar o potencial de inóculo natural e a diversidade de FMA. o cultivo intercalar com plantas não micorrízicas pode diminuí-lo. Baltruschat \& Dehne (1989) observaram redução no potencial de inóculo natural do solo após o cultivo intercalar de cevada (Hordeum sativum) com colza (Brassica napus), uma planta não micorrizica. 
Apesar de aumentos no potencial de inóculo natural, respostas na produção de uma ou outra das plantas associadas em plantio intercalar provavelmente dependa da composição da comunide de FMA nativos e da presença de pelo menos uma espécie de FMA dominante, efetiva e eficiente para uma ou ambas as plantas associadas.

Os FMA não apresentam especificidade nas relações fungo-hospedeiro, sendo que uma única espécie de fungo pode colonizar e se multiplicar em vários hospedeiros (Mosse, 1975). Atráves de um cultivo anterior com planta altamente micorrízica, é possível aumentar a diversidade de espécies de FMA e o potencial de inóculo natural do solo, antes da cultura definitiva ser instalada. Esta técnica de manejo possibilita a recuperação de áreas degradadas ou submetidas a longos períodos de monocultivo que resultaram em diminuição na diversidade e na atividade dos FMA e das populações microbianas em geral (Dood et al., 1990a).

Existem poucos relatos na literatura que demonstram este efeito em condições de campo. Dodd et al. (1990 a e b), trabalhando com savanas nativas nunca cultivadas, observaram que o pré-cultivo com mandioca, kudzu ou sorgo aumentou significativamente a infecção micorrízica e a produção de feijão e estilosantes (Stylosanthes capitata). A inoculação prévia do solo, realizada antes do pré-cultivo, também teve efeito positivo sobre o crescimento das plantas cultivadas em pré-cultivo (Dodd et al., 1990a). Souza et al. (1994) também observaram aumento do número de propágulos infectivos de fungos nativos em solo cultivado com sorgo. Leguminosas como feijão de porco, mucuna preta e guandú também aumentaram o número de esporos no solo, mas não o suficiente para se observarem diferenças estatísticas da testemunha. Espindola et al. (1994) relatam que, embora não tenha sido observada maior esporulação no solo após o cultivo de mucuna preta e crotalária. estas plantas apresentaram o maior índice de colonização radicular e promoveram o aumento na taxa de colonização da batata doce. cultivada na seqüência. A produção de tubérculos também foi aumentada com o pré-cultivo da mucuna, quando comparada à vegetação expontânea e a ausência de vegetação. Gomes-da-Costa \& Oliveira. (1996) também observaram maior peso de matéria seca de raízes e parte aérea de soja, cultivada em solos submetidos a dois ciclos de revegetação com gramíneas nativas. O manejo empregado (dois ciclos de revegetação 
por 90 dias e corte) aumentou o potencial de inóculo de FMA do solo, e as espécies utilizadas no manejo (mucuna preta e gramíneas nativas) atuaram de forma diferenciada sobre as populações de FMA.

Estes resultados evidenciam a importância do manejo sobre a micorrização e indicam que o cultivo de plantas altamente micotróficas em áreas degradadas ou solos com baixo potencial de produção pode facilitar sua integração no processo produtivo, através do aumento no potencial de inóculo natural de FMA do solo e na diversidade de espécies, contribuindo para a sustentabilidade dos agrossistemas.

\subsection{Técnicas moleculares e a identificação dos fungos MA}

Em situações de campo, avaliações da populações requerem a identificação acurada de espécies e a quantificação de densidades de propágulos e infectividade. Até o presente, bioensaios de vários tipos são usados para avaliar a infectividade do solo. Estes bioensaios têm a vantagem de incluir todos os propágulos do solo, mas dão somente uma limitada informação sobre a composição das espécies. $\mathrm{O}$ isolamento de esporos através de plantas hospedeiras em vasos de cultivo é o principal meio para determinar as espécies presentes, mas este método não mostra as espécies que estão realmente ativas. colonizando as plantas. Agora, estas limitações estão sendo eliminadas por novos métodos que estão sendo desenvolvidos. Estes métodos incluem anticorpos específicos. provas de DNA e PCR (Polimerase chain reaction) usando primers especificos, que podem auxiliar na identificação de espécies no solo a partir de um único esporo ou mesmo permitir sua identificação internamente nas raizes.

A caracterização genética dos organismos requer a presença de marcadores moleculares precisos e facilmente detectáveis. Os marcadores morfológicos, apesar de serem úteis em estudos de laboratório, são raros e pouco observados em populações naturais de fungos, apresentando limitado número de alelos e possuindo freqüentes efeitos fenotípicos adversos. Nesse sentido. marcadores bioquímicos e moleculares têm sido desenvolvidos para auxiliar a caracterização e os estudos de fisiologia e ecologia de fungos. 
As isoenzimas são variantes de enzimas especificas, atuam como marcadores codominantes. Entretanto, apresentam algumas desvantagens como a produção de poucas bandas por enzima e a influência da idade e do tipo de micélio utilizado na análise (Michelmore \& Humbert, 1987).

Entre os marcadores moleculares mais utilizados estão o RFLP (polimorfismo de tamanho nos fragmentos de restrição), mtDNA (DNA mitocondrial), rDNA (DNA ribossomal), PCR (reação em cadeia da polimerase), o RAPD (polimorfismo pela amplificação aleatória do DNA) e o emprego destas técnicas associadas.

Nenhum marcador ou método isolado tem sido citado como ideal para identificar e classificar os fungos MA. Os pesquisadores têm utilizado métodos associados que mais se aplicam a suas linhas de pesquisa, adaptando-os a cada situação. Nesta revisão serão destacados somente aqueles marcadores mais utilizados atualmente na pesquisa com fungos MA.

\subsubsection{DNA ribossômico (rDNA)}

O rDNA tem sido extensivamente utilizado em estudos filogenéticos de fungos. $\mathrm{Na}$ maioria dos eucariotos, incluindo todos os fungos verdadeiros, o rDNA apresenta-se como um arranjo repetitivo em tandem dos três maiores genes que codificam para os diferentes tipos de rRNA, separados por espaçadores transcritos ou não (Bruns et al., 1991). As regiões gênicas de rDNA são altamente conservadas, de forma que, sondas heterólogas hibridizam-se fortemente a elas. Já os espaçadores, particularmente o espaçador intergênico (IGS), podem variar na sua seqüência significativamente, até mesmo ao nível intraespecífico.

Um dos principais alvos dos estudos de variabilidade e biodiversidade em estudos genômicos são os genes ribossômicos. Estes genes multicópias são constituídos de três regiões codificadas de diferentes tamanhos (18S; 5.8S e 25-28S) separados por duas seqüências não traduzidas (ITS, espaços intragênicos transcritos). As regiões codificadas têm sido suficientemente conservadas durante a evolução e permitem o desenho de primers específicos para o gene ribossômico. As seqüências ITS, separando 
a região 5,8S da $18 \mathrm{~S}$ e $25-28 \mathrm{~S}$ são variáveis e podem ser usadas para diferenciar espécies proximamente relacionadas (White et al., 1990).

Sondas podem ser construídas pela comparação entre os padrões de variabilidade intragênico e das regiões inter-gênicas. Seqüências de rRNAs (ou rDNAs) de várias subunidades dos ribossomos são regiões extensivamente investigadas para análises filogenéticas e desenvolvimento de sondas. Os genes são úteis porque 1) eles existem em cópias múltiplas e são facilmente detectados durante procedimento de hibridização 2) as regiões gênicas são evolutivamente conservadas e muitos pesquisadores tem sondas (para hibridização) e primers (para PCR e análise de seqüência de nucleotídeos) apropriados para muitos usos, 3) existem conhecimentos substanciais de rRNA em eucariotos, 4) as regiões inter-gênicas adjacentes a regiões gênicas são altamente variáveis, entre espécies relacionadas, sendo possível comparações entre taxons relacionados. Como cada subunidade ribossomal difere em tamanho e quantidade as seqüências dentro da subunidade variam.

Em fungos MA, o primeiro gene sequenciado foi a região codificada rRNA $18 \mathrm{~S}$ de Glomus intraradices e Gigaspora margarita (Simon et al., 1992). Ao comparar as seqüências obtidas com as seqüências $18 \mathrm{~S}$ rRNA conhecidas de outros fungos, esses autores foram capazes de gerar um primer específico para FMA. Usando este primer em combinação com primers universais, seqüências quase completas de nucleotídeos para o gene 18S foram obtidas para doze diferentes FMA (Simon et al., 1993). Variabilidade e similaridade nestas seqüências foram usadas para analisar relações filogênicas entre os fungos com base no fato de que a taxa de substituição de nucleotídeos é correlacionada com a divergência entre espécies. A árvore filogênica resultante foi coincidente com a classificação do FMA estabelecida por morfologia.

Simon et al. (1993) desenvolveram primers potencialmente úteis para desenvolver uma sonda de um taxon específico. Os primers designados VALETC. VAGLO, VAACAU e VAGIGA foram desenvolvidos para a discriminação entre 4 grupos de espécies ou gêneros endomicorrizicos (respectivamente G.etunicatum. Glomus sp., Acaulospora e Gigaspora). Na região amplificada com o uso do primer VANS1 foram determinadas diferenças substanciais nas seqüências de DNA dos 
representantes de três famílias conhecidas, obtendo-se os primers citados anteriormente. Entretanto, havia rara ocorrência de diferenças intra-famílias para G.etunicatum e, por isso, foi sugerido ser colocado em uma família separada. Consequentemente, 4 grupos distintos foram considerados e a amplificação de primers específicos para taxons nas seqüências $18 \mathrm{~S}$ que pode discriminar entre eles, foram delineados. A especificidade desses 4 primers, quando usado em conjunto com o primer VANS1 específico para Glomales, foi testada em amplificações conduzidas em fragmentos SSU previamente obtidos de um número de fungos endomicorrízicos.

Similarmente, outros primers ou sondas de regiões informativas alvo deste mesmo gene puderam ser delineadas para discriminar entre alguns gêneros ou espécies. o que pode ser útil no contexto de experimentos controlados. Esta estratégia é dependente da disponibilidade de seqüências de todas as espécies a serem identificadas. Infelizmente, as seqüências $18 \mathrm{~S}$ estão no momento disponíveis apenas para 12 espécies de fungos endomicorrízicos.

Por ser baseado no PCR, a sensitividade deste procedimento de identificação é teoricamente suficiente para ser usado em amostras muito pequenas de raízes colonizadas. Protocolos de extração podem precisar de otimização para consistentemente produzir DNA amplificável de fungos de raízes de uma variedade de espécies de plantas que podem ser colonizadas por fungos endomicorrízicos arbusculares.

\subsubsection{PCR (reação em cadeia da polimerase)}

PCR permite a amplificação in vitro de uma região de DNA entre dois segmentos reconhecidos pelos primers específicos. Quantidades de picogramas de DNA podem ser amplificadas a valores que podem ser detectados e analisados pelos métodos de biologia molecular convencional. Por exemplo, Steffan \& Atlas (1988) após amplificar amostras com PCR. detectaram DNA específico de uma célula bacteriana (ex: 0.3 pg de DNA inicial ) por grama de sedimento. Lee \& Taylor (1990) usaram o método para analisar seqüência de genes rRNA de um único esporo de Neurospora tetrasperma. O método 
tem igual importância tanto em biologia molecular como para o desenvolvimento de hibridação e métodos de enzimas de restrição.

A técnica tem aumentado grandemente a capacidade para analisar seqüências usadas para determinar variabilidade em regiões de gene rDNA entre organismos. Se invariavelmente seqüências em uma região são conhecidas, então primers para amplificação podem ser construídos. Após a região ser amplificada é possível mapear a seqüência para comparação com fragmentos similares de outros indivíduos. Após comparadas, regiões de variabilidade apropriada (especificidade) podem ser identificadas e seqüências reconstruídas para uso como sondas (para identificação), primers adicionais (para PCR) para identificação individual ao nível taxonômico desejado (Bruns et al., 1991; White et al., 1990) e sondas de DNA e RNA (Schowalter \& Sommer,1989). Devido ao desenvolvimento de PCR tornou-se possível analisar e caracterizar espécies ao nível de DNA a partir de pequenas quantidades de material, tal como um esporo apenas de FMA.

\subsubsection{RAPD (polimorfismo pela amplificação aleatória do DNA)}

Esta classe de marcadores moleculares permite identificar o grau de similaridade entre genótipos, aos níveis inter e intra-específico, de maneira mais rápida. A técnica é baseada na amplificação de fragmentos não específicos de DNA. A estratégia é utilizar oligonucleotídeos de 10-15 bases como iniciadores (primers) para amplificar o DNA genômico, utilizando a reação de polimerase em cadeia - PCR.

A técnica RAPD difere da PCR por utilizar apenas um primer de seqüência arbitrária. por reação, enquanto no outro se utilizam 2 primers com seqüência conhecida de inserção. A amplificação ocorrerá quando um primer desta mesma seqüência reconhecer um sítio de homologia em uma das fitas e também o mesmo sítio, porém com orientação invertida, na outra fita da molécula de DNA, dentro do intervalo limite da PCR - 4Kb (Williams et al., 1990). O RAPD é uma técnica altamente sensível a diferenças de nucleotídeos entre o primer e o DNA molde, incluindo diferenças em um único nucleotídeo. Além disso, marcadores RAPD podem ser mapeados para regiões do genoma que são inacessíveis para análise de RFLP pela existência de DNA repetitivo. 
Outras vantagens desta técnica são a rapidez, e o não envolvimento de hibridação ou radioatividade. Além disso, requer pequena quantidade de DNA.

As principais aplicações do RAPD são o mapeamento, classificação de linhagens de uma espécie, caracterização molecular de populações e espécies, identificação de raças patogênicas, identificação de marcadores ligados a genes de interesse, e estudos de genética de populações e epidemiologia.

Para fungos MA, dependendo do primer usado o padrão da banda de fragmentos de DNA varia e pode ser específico a nível de espécie. Wyss \& Bonfante (1993) usaram RAPD para determinar o polimorfismo entre FMA. Eles mostraram que a similaridade nos perfis da banda obtida depois da amplificação pelo RAPD foi maior nos esporos do mesmo isolado e menor entre espécies diferentes. A vantagem desse método é que ele não requer o conhecimento prévio da seqüência do DNA, porque os fragmentos de DNA são amplificados aleatoriamente. No entanto, esse método tem sérios problemas. Os primers usados não são específicos e o DNA presente em qualquer organismo em contaminação pode levar à amplificação de um fragmento de DNA e resultar em padrão de banda não específico. Isto é de particular preocupação para pesquisa da micorriza arbuscular. Como o fungo não pode geralmente ser produzido assépticamente, a contaminação por bactérias é dificil de ser evitada. Ainda mais, esse método não pode ser usado diretamente para identificar o fungo dentro das raízes, devido à interferência do DNA da planta. Contudo, resultados recentes têm mostrado que esse método é mais sensível que o uso de isoenzimas (Wang, 1993) e ele pode levar ao isolamento de fragmentos específicos de DNA. para os quais primers correspondentes podem ser gerados. Estes primers podem então ser usados combinados com análise de variabilidade do PCR-RFPL ou. se espécie-específico. na investigação para detectar um dado fungo.

\subsubsection{Análises de isoenzimas}

Informação sobre a condição genética e nuclear do fungo isolado podem ser obtidas através de análises de isoenzimas. Isoenzimas são proteínas que têm a mesma atividade enzimática mas são codificadas por alelos diferentes do mesmo locus genético (aloenzimas). ou por loci genéticos separados. Isso dá origem a uma estrutura terciária 
diferente da proteína e, consequentemente, mobilidades eletroforéticas diferentes no gel (Micales et al., 1986). Bandas de aloenzimas migram rigorosamente juntas, embora isoenzimas codificadas por loci diferentes ocorram em diferentes regiões do gel.

Vários sistemas de isoenzimas têm sido estudados em FMA e tem sido sugerido, a partir de análises de padrão de bandas, que esses fungos podem ser haplóides (Rosendahl \& Sen, 1992). Como os padrões de banda representam diretamente os genes do produto, eles podem revelar diferenças genéticas entre os fungos proximamente relacionados. A análise de isoenzimas tem sido particularmente aplicada aos membros do gênero Glomus, onde variações no padrão de bandas do alelo e do locus da isoenzima ocorrem entre espécies e isolados. Hepper et al. (1988) relata diversidade genética aparente entre isolados reconhecidos como G.mosseae mas, de diferentes origens geográficas. Contudo, a amplitude da variabilidade da isoenzima depende muito da enzima em questão. Uma análise genética ampla requer testes de um grande número de sistemas de diferentes enzimas. A utilidade de padrão de variabilidade da isoenzima como um critério taxonômico em FMA, em conjunto com caracteres morfológicos é discutida por Rosendahl \& Sen (1992).

Atualmente tem sido largamente difundido o uso de leguminosas para revegetação de solos degradados ou como adubação verde em culturas perenes ou áreas que permanecem longos períodos sem vegetação. Este conceito se baseia no fato das leguminosas serem capazes de formar dois tipos de associações simbióticas mutualísticas com microrganismos do solo, Rizóbio fixadores de $\mathrm{N}_{2}$ e micorrizas arbusculares (Cardoso, 1985; Azcón-Aguilar et al., 1979). Tal fato tem grande significado ecológico, porque, embora a fixação de $\mathrm{N}_{2}$ seja um processo chave na disponibilidade de $\mathrm{N}$ para a biosfera, é dependente do suprimento de fosfatos e outros nutrientes. As micorrizas podem satisfazer esta demanda para ambos os simbiontes, planta e fixador de $\mathrm{N}_{2}$, com uma relação sinergística entre o FMA e o Rizóbio (Barea \& Azcón-Aguillar, 1983). Leguminosas noduladas e colonizadas com FMA são bem adaptadas a cultivos em situações de deficiência.

O potencial de inóculo de fungos micorrízicos arbusculares (FMA) relaciona-se ao número de esporos e fragmentos de hifas presentes no solo e pode ser influenciado 
pela vegetação. Assim como o substrato para produção de mudas pode ser melhorado através da inoculação, é possível, através do manejo, aumentar o potencial de inóculo natural de FMA do solo. Plantas altamente micorrízicas introduzidas no agrossistema como adubos verdes ou como cobertura de solo podem aumentar a diversidade de espécies de FMA e a quantidade de propágulos e hifas no solo, elevando o potencial infectivo natural e favorecendo a micorrização das culturas.

A avaliação do potencial de inóculo natural do solo e da dinâmica das diferentes populações de FMA indígenas de cafeeiros, conduzidos com adubos verdes, permitirá o conhecimento dos possíveis efeitos desta prática agrícola sobre a ecologia dos FMA indígenas e o potencial de inóculo natural do solo. 


\section{MICORRIZAS ARBUSCULARES NO AGROSSISTEMA CAFEEIRO E ADUBAÇÃO VERDE COM LEGUMINOSAS}

\subsection{Resumo}

Avaliou-se o efeito do cultivo intercalar de leguminosas de verão para adubação verde, sobre a ocorrência de fungos micorrízicos arbusculares (MA) no cafeeiro. As avaliações foram feitas em um experimento de longa duração, conduzido a campo pelo Instituto Agronômico do Paraná- IAPAR, no município de Mirasselva, PR. O experimento está instalado há 10 anos, em uma área de latossolo vermelho escuro distrófico (LEd) onde. nas linhas principais cultiva-se o cafeeiro 'Catuaí Amarelo' e nas entrelinhas as leguminosas Leucena (Leucaena leucocephala), Crotalaria spectabilis, $C$. breviflora. Mucuna cinzenta (Stizolobium pruriens), Mucuna anã (Stizolobium deeringianum), Amendoim cavalo (Arachis hipogeae) e Caupi (Vigna unguiculata) para adubação verde. Amostras de solo rizosférico e raízes foram coletadas entre junho de 1996 e julho de 1997. Determinou-se a diversidade de espécies de fungos MA através da identificação morfológica dos esporos, a freqüência de ocorrência das populações de fungos MA através da contagem direta de esporos no solo e a colonização radicular. Também foram conduzidos bioensaios em casa de vegetação, para estudar a composição das populações de fungos MA que efetivamente estavam colonizando raízes do cafeeiro a campo.

O cultivo de leguminosas na entrelinha de plantio do cafeeiro aumentou a diversidade de espécies e o número de esporos de fungos MA na rizosfera do cafeeiro. Cafeeiro cultivado com Crotalaria breviflora mostrou-se altamente micorrizado, com maior diversidade de espécies e número de esporos de fungos MA no solo. em todas as épocas avaliadas. Entretanto, parte da diversidade de fungos presentes na rizosfera do cafeeiro não foi recuperada na rizosfera de milho (Zea mays L.) e sorgo (Sorghum bicolor L.) quando se utilizaram raízes colonizadas de cafeeiro como inóculo, indicando que alguns fungos MA observados na rizosfera do cafeeiro podem estar sendo 
multiplicados nas leguminosas que crescem próximas, mas não estão efetivamente em simbiose com o cafeeiro. Estes resultados sugerem a ocorrência de relações preferenciais entre fungos e hospedeiros, que podem influenciar o estabelecimento e eficiência da simbiose micorrízica e determinar a exclusão de algumas espécies de fungos MA do sistema solo-planta.

\subsection{Summary: ARBUSCULAR MYCORRHIZAL FUNGI IN AN AGROSYSTEM WITH COFFEE PLANTS INTERCROPPED WITH LEGUME AS GREEN MANURE}

Sporulation and occurrence of arbuscular mycorrhizal fungi (AM) were evaluated on coffee trees (Coffea arabica L.) intercropped with legumes for green manure. Samples of soil rhizosphere and roots were collected at three times between June of 1996 and July of 1997, in a long term experiment located at the Instituto Agronômico do Paraná IAPAR, at Mirasselva city, Paraná state, Brazil. The AM diversity was determined through the morphologic identification of spores, the AM occurrence frequency by the direct counting of spores in the soil and the root colonization evaluated with the grid-line method using stained roots. Bioassays were also conducted at the green-house, to study the AM composition inside of the coffee roots from the field. Legume intercropping increased the AM diversity and the number of spores in the soil rizosphere of coffee trees. Crotalaria breviflora showed a high mycorrhizal capacity, able to form symbiosis with several species of AM fungi, resulting in more AM diversity and number of spores in the soil, at all evaluation periods. This effect was also observed in the coffee rhizosphere cultivated side by side to the legumes. However, part of the AM diversity in the coffee trees rhizosphere was not recovered in corn (Zea mays L.) and sorgum (Sorghum bicolor L.) rhizosphere when colonized roots of coffee were used as inoculum, suggesting that some of the AM fungi observed in the coffee rizosphere were originated from close legume roots. but they are not indeed in symbiosis with the coffee trees. These results showed the occurrence of preferential relationships among the AM 
fungi and the host, that can determine the establishment and the effectiveness of the mycorrhizal symbiosis and the exclusion of some species from the root system of certain plants.

\subsection{Introdução}

As micorrizas arbusculares (MA) são associações simbiotróficas entre fungos da ordem Glomales e raízes da maioria das plantas vasculares. As MA atuam como um complemento do sistema radicular do hospedeiro, capaz de aumentar a absorção de $\mathrm{P}$ e outros nutrientes, promover proteção contra patógenos e desencadear no hospedeiro diversos efeitos ainda não de todo compreendidos. Os efeitos da micorrização para as plantas podem ser tão mais importantes quanto menos desenvolvido for o sistema radicular, mais estressante o ambiente, mais pobre o solo em nutrientes ou mais competitivo para o estabelecimento das plantas. A simbiose micorrízica é particularmente importante para o cafeeiro porque este apresenta elevada dependência aos fungos MA na fase de mudas em viveiros (Siqueira \& Colozzi Filho, 1986). Em plantas adultas no campo, embora a dependência micorrízica do cafeeiro ainda não tenha sido determinada, Saggin Júnior \& Siqueira (1996) citam que a manutenção de uma população de fungos MA diversificada e ativa pode aumentar a sustentabilidade do agrossistema e diminuir os efeitos negativos que o monocultivo contínuo pode ter sobre a diversidade de espécies, conforme relatado por Johnson et al. (1992).

Em viveiros. a inoculação do cafeeiro com espécies de fungos MA eficientes estimula o estabelecimento da simbiose no início do desenvolvimento das plantas, proporcionando mudas sadias e mais resistentes aos estresses causados pelo transplantio, o que pode se transformar em aumento de produtividade nas plantas adultas. Entretanto, as informações sobre a ocorrência de fungos MA em cafeeiros não inoculados em produção mostram a ocorrência predominante de espécies indígenas de baixa eficiência simbiótica (Balota \& Lopes, 1996a). Espécies selecionadas eficientes normalmente não ocorrem no campo (Lopes et al.. 1983a) e quando introduzidas via inoculação. têm 
dificuldade de permanecer no agrossistema (Balota \& Lopes, 1996b). Consequentemente, é necessário entender como espécies individuais afetam as plantas sob condições de campo e que fatores controlam sua população nos agrossistemas (Abbott \& Robson, 1982, Hall, 1988).

Diversos estudos têm examinado os efeitos de rotações de cultivos e pré-cultivos na colonização micorrízica e nas populações de esporos ( Sieverding \& Leihner, 1984; Dood et al., 1990b; Johnson et al., 1992), mas pouco se conhece dos efeitos destas práticas sobre a comunidade de fungos micorrízicos em cafeeiros adultos.

O objetivo deste trabalho foi estudar o efeito do cultivo intercalar do cafeeiro com leguminosas de verão para adubação verde, sobre a ocorrência de fungos MA e a micorrização.

\subsection{Material e Métodos}

Este estudo foi realizado em amostras de solo rizosférico e raízes coletadas a campo e em ensaios complementares conduzidos em casa de vegetação, conforme descritos a seguir.

\subsubsection{Campo}

Amostras de solo rizosférico e raízes de cafeeiros (Coffea arabica L.) e leguminosas foram coletadas em um experimento de longa duração conduzido pelo Instituto Agronômico do Paraná- IAPAR, no município de Mirasselva, PR. Este trabalho vem sendo conduzido desde 1988 e objetiva estudar os efeitos do cultivo intercalar de adubos verdes sobre as propriedades do solo e a produtividade do cafeeiro. O experimento esta instalado em uma área de latossolo vermelho escuro distrófico (LEd). Nas linhas principais cultiva-se o cafeeiro 'Catuaí Amarelo' e nas entrelinhas as leguminosas Leucena (Leucaena leucocephala), Crotalaria spectabilis, C. breviflora, Mucuna cinzenta (Stizolobium pruriens), Mucuna anã (Stizolobium deeringianum), Amendoim cavalo (Arachis hipogeae) e Caupi (Vigna unguiculata). No tratamento 
controle, conduz-se o cafeeiro no limpo, sem leguminosas e invasoras na entrelinha. $\mathrm{O}$ delineamento experimental a campo é de blocos ao acaso, com 3 repetições. O cafeeiro é cultivado no espaçamento $4,0 \times 2,0$ m por cova de 2 plantas e cada parcela possui 32 covas (4 linhas de 8 covas), sendo as 8 plantas centrais a área útil da parcela. Com exceção das leucenas que são perenes, as leguminosas são plantadas anualmente, sendo a semeadura feita na primeira quinzena de outubro. A densidade de sementes varia em função da espécie. No tratamento controle, o cafeeiro é conduzido no limpo, procedendo-se a capinas manuais durante o ano, conforme o desenvolvimento das invasoras. As leguminosas são cortadas na altura do solo, por ocasião da floração, que ocorre em épocas diferentes para cada espécie, deixando-se os resíduos amontoados na área para cobertura do solo e decomposição. Para a Leucena, são feitos 4 cortes ao ano, normalmente nos meses de outubro, janeiro, março e maio.

Foram feitas 3 amostragens, sendo a primeira em julho de 1996, e as duas seguintes em fevereiro e junho de 1997, compreendendo um ano agrícola. Coletaram-se amostras compostas (4 sub-amostras por parcela) com aproximadamente $1 \mathrm{~kg}$ de material cada, contendo raízes e solo rizosférico a uma profundidade de 0 a $20 \mathrm{~cm}$. Para o cafeeiro, as sub-amostras foram coletadas em 4 pontos eqüidistantes sob a projeção da copa e orientados para as direções norte, sul, leste e oeste. Nas leguminosas, as sub-amostras foram coletadas alternadas na linha de plantio.

Do material amostrado (solo e raízes), $100 \mathrm{~g}$ de solo foram utilizadas para análises químicas de rotina e $50 \mathrm{~g}$ de solo para determinações quantitativas (número de esporos) e qualitativas (diversidade de espécies) de fungos MA. O restante do solo foi utilizado para a montagem do ensaio de casa de vegetação.

A análise química do solo no campo, nas três épocas amostradas é apresentada na Tabela 1.

\subsubsection{Casa de vegetação}

$\mathrm{Na}$ tentativa de multiplicar os fungos que efetivamente estavam colonizando as raízes das plantas no experimento a campo, foram montados vasos de multiplicação usando como inóculo raizes de cafeeiro e leguminosas coletadas a campo. Seguiu-se o 
mesmo delineamento experimental do experimento a campo, com 3 repetições, tendo sido montados vasos de multiplicação correspondentes as três épocas amostradas. Entretanto, devido ao ciclo rápido de algumas leguminosas não foi possível obter raízes destas plantas por ocasião da $1^{\circ}$ e $3^{\circ}$ amostragens, que portanto não foram avaliadas em casa de vegetação nestas épocas.

Tabela 1. Análise química de solo coletado na profundidade de 0 a $20 \mathrm{~cm}$ em experimento de cafeeiro e adubação verde com leguminosas de verão, conduzido pelo Instituto Agronômico da Paraná-IAPAR no município de Mirasselva, PR. Média de 72 repetições.

\begin{tabular}{lccccccc}
\hline & $\mathrm{pH}$ & $\mathrm{C}$ & $\mathrm{P}$ & $\mathrm{K}$ & $\mathrm{Ca}$ & $\mathrm{Mg}$ & $\mathrm{Al}$ \\
\cline { 5 - 8 } & & $\left(\mathrm{g} \mathrm{dm}^{-3}\right)$ & $\left(\mathrm{mg} \mathrm{dm}^{-3}\right)$ & & $\left(\mathrm{cmol}_{\mathrm{c}} \mathrm{dm}^{-3} \mathrm{de} \mathrm{solo}\right)$ & \\
\hline Cafeeiro & 4,06 & 8,19 & 28,23 & 0,18 & 0,7 & 0,44 & 0,4 \\
Leguminosas & 5,00 & 7,92 & 5,46 & 0,21 & 1,9 & 1.10 & 0,0 \\
\hline
\end{tabular}

Como substrato nos vasos de cultivo utilizou-se uma mistura de solo latossolo vermelho escuro distrófico (Led) e areia, na proporção de 3:1 vol.:vol., desinfestado com brometo de metila. Como planta hospedeira utilizou-se milho (Zea mavs L.) e sorgo (Sorghum bicolor L.) cultivados simultaneamente. O inóculo constou de $100 \mathrm{~g}$ de raízes recém colhidas, lavadas e picadas em fragmentos de aproximadamente $1 \mathrm{~cm}$. Estas raízes foram colocadas abaixo do orifício de plantio, no momento da semeadura. Os vasos foram conduzidos em casa de vegetação, por 5 meses, tempo suficiente para que as plantas completassem seu ciclo, quando então foram avaliadas.

Para estudar o efeito seletivo da planta sobre os fungos MA nativos. cultivou-se a mesma espécie de cafeeiro utilizada no experimento a campo, em casa de vegetação, porém em solos coletados a campo, na projeção da copa do cafeeiro e na linha de plantio das leguminosas. Utilizou-se solo da primeira coleta (Junho de 1996) sendo o ensaio montado no mesmo delineamento experimental do campo, com 3 repetições.

Para o cultivo do cafeeiro em casa de vegetação utilizou-se sacos de polietileno para produção de mudas. com capacidade para $600 \mathrm{ml}$ de solo. As plantulas foram 
obtidas de sementes desinfestadas e pré-germinadas em vermiculita estéril, sendo transplantadas em estádio de "orelha de onça". O ensaio foi conduzido por onze meses, tendo sido colhido quando o cafeeiro estava com três pares de folhas e desenvolvimento vegetativo suficiente para ser transplantado no campo.

\subsubsection{Avaliações}

Os esporos foram extraídos do solo por peneiramento úmido, conforme Gerdemann \& Nícolson (1963) e centrifugados em água a $3000 \mathrm{rpm}$ por $3 \mathrm{~min}$ e em sacarose $50 \%$ a $2000 \mathrm{rpm}$ por $2 \mathrm{~min}$. Após a extração os esporos foram transferidos para placas de Petri e contados sob microscópio estereoscópio (40X). Para as determinações qualitativas (identificação de espécies) os esporos foram fixados com PVL (Polivinilalcool) em lâminas microscópicas e observados em microscópio óptico composto. A identificação das espécies foi feita baseando-se em critérios morfológicos, conforme descrito em Schenck \& Perez (1987) e Morton \& Beny (1990).

Para a determinação da colonização radicular por fungos MA, as raizes foram separadas do solo rizosférico em água corrente, lavadas e aquecidas a $60^{\circ} \mathrm{C}$ em KOH $10 \%$ por 10 minutos para clarificação. Após a clarificação as raízes foram lavadas em água destilada 4 vezes, acidificadas com $\mathrm{HCl} 1 \%$ por 2 minutos e fervidas por 10 minutos em solução de glicerol-ácido + azul de tripano $0.05 \%$ para colorir as estruturas fúngicas internas, segundo Phillips \& Hayman (1970). A determinação da percentagem de colonização radicular foi feita em microscópio estereoscópio, pelo método da placa quadriculada, segundo Giovannetti \& Mosse (1980).

Os dados obtidos foram transformados sendo os de porcentagem de colonização radicular previamente transformados para $\operatorname{arc} \operatorname{sen}(\mathrm{x} / 100)^{1 / 2}$ e o número de esporos para $(x+0.5)^{1 / 2}$. Estes dados foram então submetidos à análise de variância com a aplicação do teste de F. sendo as médias comparadas pelo teste de Duncan. 


\subsection{Resultados}

A esporulação dos fungos MA a campo, na rizosfera do cafeeiro e das leguminosas cultivadas nas entrelinhas, nas três épocas estudadas, são apresentados na Tabela 2.

Tabela 2. Esporulação de fungos micorrízicos arbusculares na rizosfera de cafeeiro (Coffea arabica L.) e de leguminosas cultivadas de modo intercalar a campo. Média de 3 repetições.

\begin{tabular}{ccccccc}
\hline & \multicolumn{3}{c}{ Cafeeiro } & \multicolumn{3}{c}{ Cultivo intercalar } \\
\cline { 2 - 7 } Leguminosas & Jun./96 & Fev./97 & Jul./97 & Jun./96 & Fev./97 & Jul./97 \\
& & Número de esporos . 50 g de solos & \\
\hline Leucena & $61 \mathrm{Ab}^{(1)}$ & $21 \mathrm{Babc}$ & $46 \mathrm{Ab}$ & $82 \mathrm{Abc}$ & $51 \mathrm{Aa}$ & $56 \mathrm{Aabc}$ \\
Crotalaria spectabilis & $72 \mathrm{Ab}$ & $24 \mathrm{Babc}$ & $85 \mathrm{Aab}$ & $123 \mathrm{Aab}$ & $68 \mathrm{Aa}$ & $70 \mathrm{Aab}$ \\
C. breviflora & $131 \mathrm{Aa}$ & $39 \mathrm{Ba}$ & $128 \mathrm{Aa}$ & $167 \mathrm{Aa}$ & $69 \mathrm{Ba}$ & $106 \mathrm{Aba}$ \\
Mucuna cinzenta. & $80 \mathrm{Ab}$ & $24 \mathrm{Babc}$ & $55 \mathrm{Ab}$ & $60 \mathrm{Ac}$ & $65 \mathrm{Aa}$ & $22 \mathrm{Bd}$ \\
M. anã & $67 \mathrm{Ab}$ & $19 \mathrm{Bbc}$ & $61 \mathrm{Ab}$ & $68 \mathrm{Ac}$ & $40 \mathrm{Aba}$ & $23 \mathrm{Bd}$ \\
Amendoim cavalo & $50 \mathrm{Ab}$ & $19 \mathrm{Bbc}$ & $84 \mathrm{Aab}$ & $67 \mathrm{Abb}$ & $70 \mathrm{Aa}$ & $33 \mathrm{Bbcd}$ \\
Caupi & $58 \mathrm{Ab}$ & $15 \mathrm{Bc}$ & $50 \mathrm{Ab}$ & $78 \mathrm{Abc}$ & $66 \mathrm{Aba}$ & $33 \mathrm{Bbcd}$ \\
Controle & $49 \mathrm{Ab}$ & $30 \mathrm{Bab}$ & $63 \mathrm{Aab}$ & $61 \mathrm{Ac}$ & $62 \mathrm{Aa}$ & $29 \mathrm{Acd}$ \\
\hline Total & $68 \mathrm{~A}$ & $23 \mathrm{~B}$ & $68 \mathrm{~A}$ & $75 \mathrm{~A}$ & $60 \mathrm{~A}$ & $40 \mathrm{~B}$ \\
\cline { 2 - 7 } C..$\%$ & & 8.4 & & & 10,6 &
\end{tabular}

1.Médias seguidas de mesma letra maiúsculas na linha e minúsculas na coluna não diferem entre si pelo teste de Duncan a $5 \%$ de probabilidade.

O cultivo de Crotalaria breviflora nas entrelinhas de plantio aumentou a concentração de esporos na rizosfera do cafeeiro em todas as épocas analisadas embora em fevereiro este efeito não tenha sido estatisticamente significativo. Em cafeeiros cultivados com outras leguminosas na entrelinha observou-se tendência de efeitos 
variados sobre a esporulação no solo. Por exemplo, Caupi estimulou a esporulação na rizosfera do cafeeiro em julho, mas em fevereiro o número de esporos observados foi significativamente menor. Na rizosfera das leguminosas (Tabela 2), o maior número de esporos também foi observado em Crotalaria breviflora, em junho e julho, seguido pela C.spectabilis em Junho e C. spectabilis e Leucena em julho. No verão (Fev./96), não se observaram diferenças entre o número de esporos recuperados na rizosfera das leguminosas. As maiores esporulações foram observadas em junho e julho no cafeeiro e em junho nas leguminosas.

A percentagem de colonização radicular no cafeeiro (Figura 1A) e na Leucena (Figura 1B) cultivados a campo é apresentada na Figura 1.

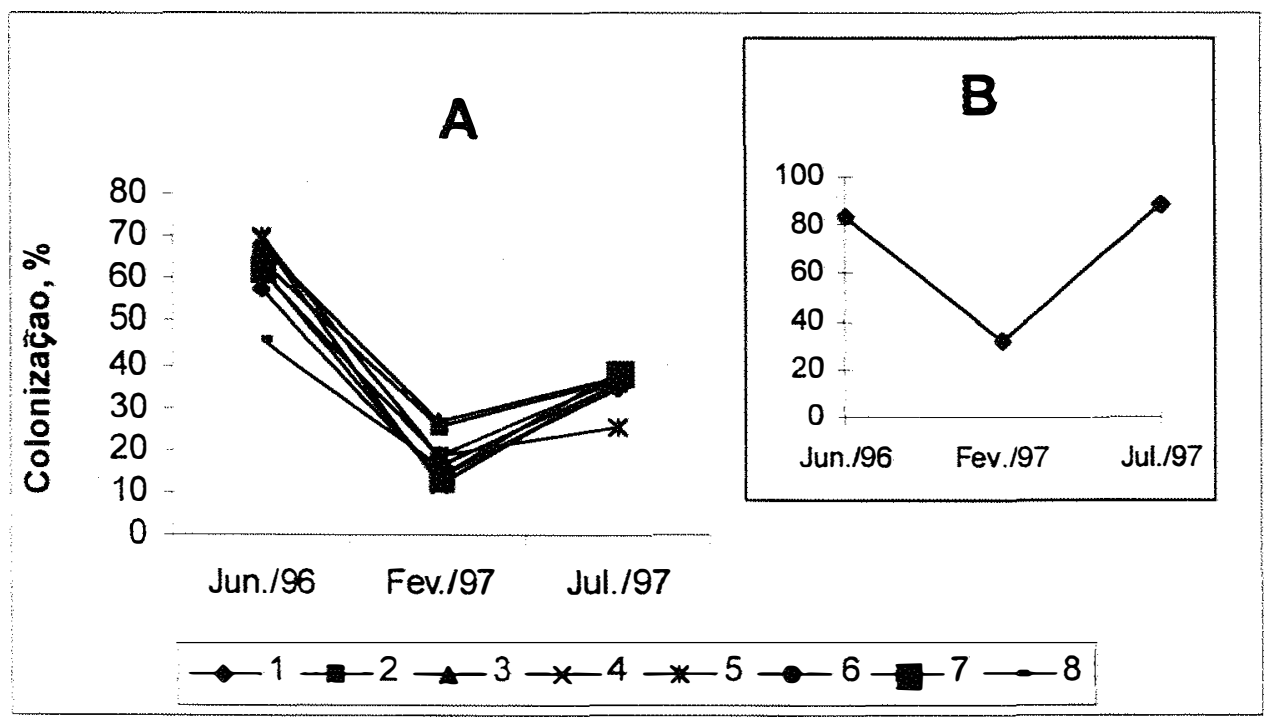

Figura 1. Colonização radicular de fungos micorrízicos arbusculares em A): cafeeiro cultivado a campo com leguminosas na entrelinha e B): Leucena cultivada na entrelinha do cafeeiro. Média de três repetições. 1 a 7 referem-se aos tratamentos onde se cultiva cafeeiro com as leguminosas Leucena. Crotalaria spectabilis, C. breviflora, Mucuna cinzenta, M. anã, Amendoim cavalo e Caupi na entrelinha, respectivamente. 8 cafeeiro cultivado na ausência de leguminosas (Controle). 
Não se observaram diferenças significativas na colonização radicular do cafeeiro quando cultivado com diferentes leguminosas na entrelinha. Entretanto, esta foi significativamente maior no mês de junho, mínima em fevereiro e intermediária em julho do outro ano. Para a Leucena, única leguminosa na qual a colonização pôde ser avaliada em todas as épocas por ser perene, observou-se resultado semelhante, com valores máximos no inverno e mínimo no verão. As demais leguminosas foram avaliadas apenas na amostragem de fevereiro, e todas apresentavam colonização com valores semelhantes aos observados para a Leucena (dados não apresentados).

Os fungos MA recuperados na rizosfera do cafeeiro e das leguminosas a campo, sua freqüência e classe de ocorrência são apresentados na Tabela 3. No total, em todas as épocas avaliadas foram identificadas 12 espécies de fungos MA, que são: Scutellospora gilmorei, S.pellucida, S.heterogama, Gigaspora margarita, Gi.decipiens, Acaulospora scrobiculata, A.appendicula, A.longula, A.spinosa, Acaulospora sp., Glomus sp. e G.diaphanum.

De modo geral, todos os fungos identificados na área foram de ocorrência comum no cafeeiro e nas leguminosas. Entretanto, foram observadas algumas variações nas freqüências de ocorrências de determinadas espécies em função da época e da planta hospedeira. conforme discutido no capítulo 3. Por exemplo, em junho de 96 observou-se a ocorrência de A.longula, Acaulospora sp. e Glomus sp. somente em cafeeiro e Gi.margarita. Gi.decipiens e A.appendícula apenas na Crotalária (Figura 2 do capítulo 5). Neste trabalho, a riqueza de espécies (Riqueza de espécies $=$ número de espécies recuperadas) foi maior no solo cultivado com leguminosas ou sob a influência do cultivo destas. Gi.decipiens e Acaulospora sp não foram encontrados na rizosfera do cafeeiro cultivado sem adubo verde e S.heterogama e A.appendicula não ocorreram em áreas onde o cafeeiro ou leguminosas não foram cultivados (Tabela 3). A.scrobiculata, A.longula e G.diaphanum apresentaram maior classe de ocorrência no cafeeiro (Classe 5). Nas leguminosas, além de A.scrobiculata, A.longula e G.diaphanum, S.gilmorei também apresentou classe 5 de ocorrência. Os resultados de classe de freqüência mostraram que, nas parcelas onde cresce a vegetação nativa ou onde se cultivaram leguminosas a maioria das espécies apresentaram classe de ocorrência mais alta que no 
cafeeiro, o que mostra populações mais representativas dentro de um mesmo índice de riqueza. No cafeeiro, embora tenham sido identificadas 12 espécies, com exceção de A.scrobiculata, A.longula e G.diaphanum que apresentam classe 5 de freqüência (quase sempre presentes), a maioria das espécies ocorrem com pouca freqüência (classe 2) ou rara (classe 1).

Tabela 3. Ocorrência, frequiência de ocorrência ${ }^{2}$ (F) e classe de ocorrência ${ }^{3}$ (C) de espécies de fungos micorrízicos arbusculares na rizosfera de cafeeiro e leguminosas cultivadas de modo intercalar a campo.

\begin{tabular}{|c|c|c|c|c|c|c|c|c|}
\hline \multirow{3}{*}{$\begin{array}{c}\text { Ocorrência } \\
\text { de } \\
\text { espécies }\end{array}$} & \multicolumn{4}{|c|}{ Cafeeiro } & \multicolumn{4}{|c|}{ Cultura intercalar } \\
\hline & \multicolumn{2}{|c|}{ Cafeeiro $^{4-}$} & \multicolumn{2}{|c|}{ Controle $^{3}$} & \multicolumn{2}{|c|}{ Leguminosas $^{4}$} & \multicolumn{2}{|c|}{ Controle $^{5}$} \\
\hline & $\mathrm{F}, \%$ & $\mathrm{C}$ & $\mathrm{F}, \%$ & $\mathrm{C}$ & $\mathrm{F}, \%$ & $\mathrm{C}$ & $\mathrm{F}, \%$ & $\mathrm{C}$ \\
\hline Scutellospora gilmorei & 48 & 3 & 33 & 2 & 100 & 5 & 100 & 5 \\
\hline S.pellucida & 24 & 2 & 33 & 2 & 71 & 4 & 33 & 2 \\
\hline S.heterogama & 4,8 & 1 & 33 & 2 & 28,5 & 2 & 0 & - \\
\hline Gigaspora margarita & 19 & 1 & 33 & 2 & 62 & 4 & 66 & 4 \\
\hline Gi.decipiens & 9,5 & 1 & 0 & 1 & 28,5 & 2 & 33 & 2 \\
\hline Acaulospora scrobiculata & 90 & 5 & 66 & 4 & 100 & 5 & 100 & 5 \\
\hline A.appendicula & 19 & 1 & 33 & 2 & 38 & 2 & 0 & - \\
\hline A.longula & 100 & 5 & 100 & 5 & 90 & 5 & 66 & 4 \\
\hline A.spinosa & 24 & 2 & 66 & 4 & 62 & 4 & 66 & 4 \\
\hline Acaulospora sp. & 4.8 & 1 & 0 & - & 19 & 1 & 0 & - \\
\hline Glomus sp. & 9,5 & 1 & 66 & 4 & 52 & 3 & 66 & 4 \\
\hline G.diaphanum & 100 & 5 & 100 & 5 & 86 & 5 & 100 & 5 \\
\hline \multicolumn{9}{|c|}{$\begin{array}{l}\text { 1. Ocorrência }=\text { presença na amostra. } 2 \text {. Freqüência de ocorrência }=\text { presença pelo total } \\
\text { de amostras. Classe de ocorrência segundo Braun-Blanquet }(1979) \text { : } 0=\text { esporádica }(<2) \text { : } \\
1=\text { rara }(2<20 \%) ; 3=\text { pouca frequência }(20<40 \%) ; 4=\text { presente na maioria }(60<80 \%) ; 5 \\
=\text { quase sempre presente }(80-100 \%) ; 4 \text { e } 5 \text {, média de } 63 \text { e } 27 \text { repetições. } \\
\text { respectivamente. }\end{array}$} \\
\hline
\end{tabular}


A freqüência de ocorrência de Glomales no cafeeiro e nas leguminosas é apresentada na Figura 2. Acaulosporaceae e Gigasporaceae predominam no cafeeiro e nas leguminosas, respectivamente. Para o cafeeiro, a relação de ocorrência do dominante com as demais foi de 2,3:1 para Acaulosporaceae/Gigasporaceae e 2,2:1 para Acaulosporaceae/Glomaceae. No cafeeiro controle a representatividade das populações apresentou-se mais equilibrada, indicada pela menor relação entre a ocorrência das famílias (1,3:1 nos dois casos). Nas leguminosas, a relação Gigasporaceae/Acaulosporaceae e Gigasporaceae/Glomaceae foi de 1,7:1 e 2,0:1, respectivamente. No controle das leguminosas (área sem cultivo mas de crescimento freqüente de invasoras), não se observou relação de dominância de ocorrência, embora Glomaceae tenha ocorrido com freqüência menor.

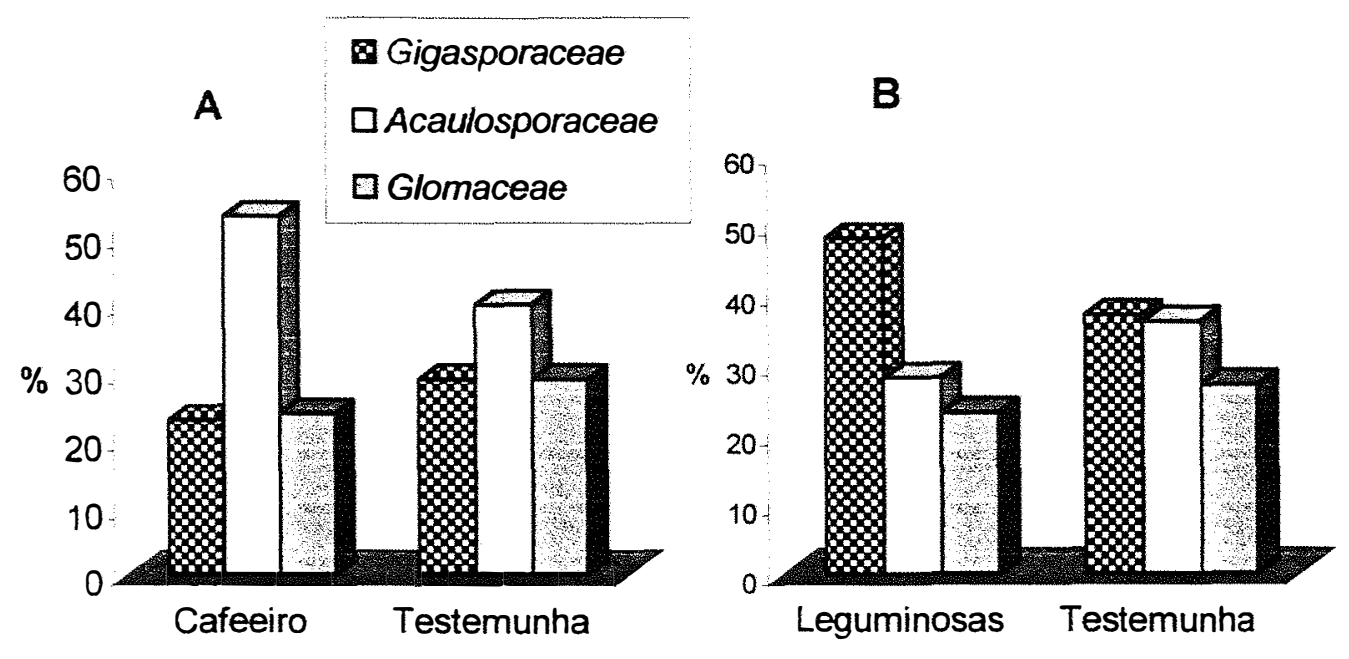

Figura 2. Freqüência de ocorrência de Glomales em cafeeiros e leguminosas cultivadas de modo intercalar a campo. Média de 63 repetições para cafeeiros e leguminosas e 21 repetições para os controles. 
Em casa de vegetação, em vasos de cultivo tendo milho e sorgo como planta hospedeira, mas inoculados com raízes de cafeeiro ou leguminosas cultivadas a campo, observou-se ocorrência e freqüência de ocorrência de espécies diferente do observado a campo (Tabela 4). Gigasporaceae não foram recuperadas na rizosfera de milho e sorgo quando o inóculo utilizado foi raízes de café, em nenhuma das épocas estudadas. Destas raízes somente se recuperou A.scrobiculata, A.longula, Glomus sp. e G.diaphanum, sendo este último com alta freqüência de ocorrência. Entretanto, Gigasporaceae, especialmente S.gilmorei foram freqüentemente recuperados de raízes das leguminosas.

Tabela 4. Ocorrência e freqüência de ocorrência de espécies de fungos micorrízicos arbusculares, na rizosfera de milho e sorgo, inoculados em casa de vegetação com raízes de cafeeiro ou leguminosas cultivadas de modo intercalar no campo.

\begin{tabular}{cccc}
\hline Ocorrência ${ }^{2}$ & \multicolumn{3}{c}{ Freqüência de ocorrência $^{2}, \%}$. \\
\cline { 2 - 4 } de espécies. & Cafeeiro $^{3}$ & Controle $^{4}$ & Leguminosas $^{3}$ \\
\hline Scutellospora gilmorei & - & - & 42 \\
S. pellucida & - & - & 4 \\
S. heterogama & - & - & 4 \\
Acaulospora scrobiculata & 51 & 89 & 33 \\
A.longula & 57 & 78 & 21 \\
Glomus sp. & 21 & 0 & 12 \\
G.diaphanum & 90 & 100 & 83 \\
\hline
\end{tabular}

1.Ocorrência $=$ presença no tratamento; 2 . Freqüência de ocorrência $=$ ocorrência da espécie no total de amostras avaliadas; 3, 4 e 5 = Média de 63, 9 e 63 repetições; respectivamente.

A esporulação observada nos vasos de cultivo com milho e sorgo em casa de vegetação variou, independentemente das épocas amostradas, de 136 a 512 esporos por $50 \mathrm{~g}$ de solos (Figura 3) e não foram observadas diferenças significativas. A produção de esporos em vasos de cultivo é normalmente alta. refletindo as condições favoráveis ao 
desenvolvimento da simbiose e do fungo. Embora não tenha sido determinada a percentagem de ocorrência de espécies com base na contagem de esporos, observou-se estreita relação entre a ocorrência de esporos de G.diaphanum e sua freqüência de ocorrência no campo (Figura 3). A presença de G.diaphanum em quase todas as épocas

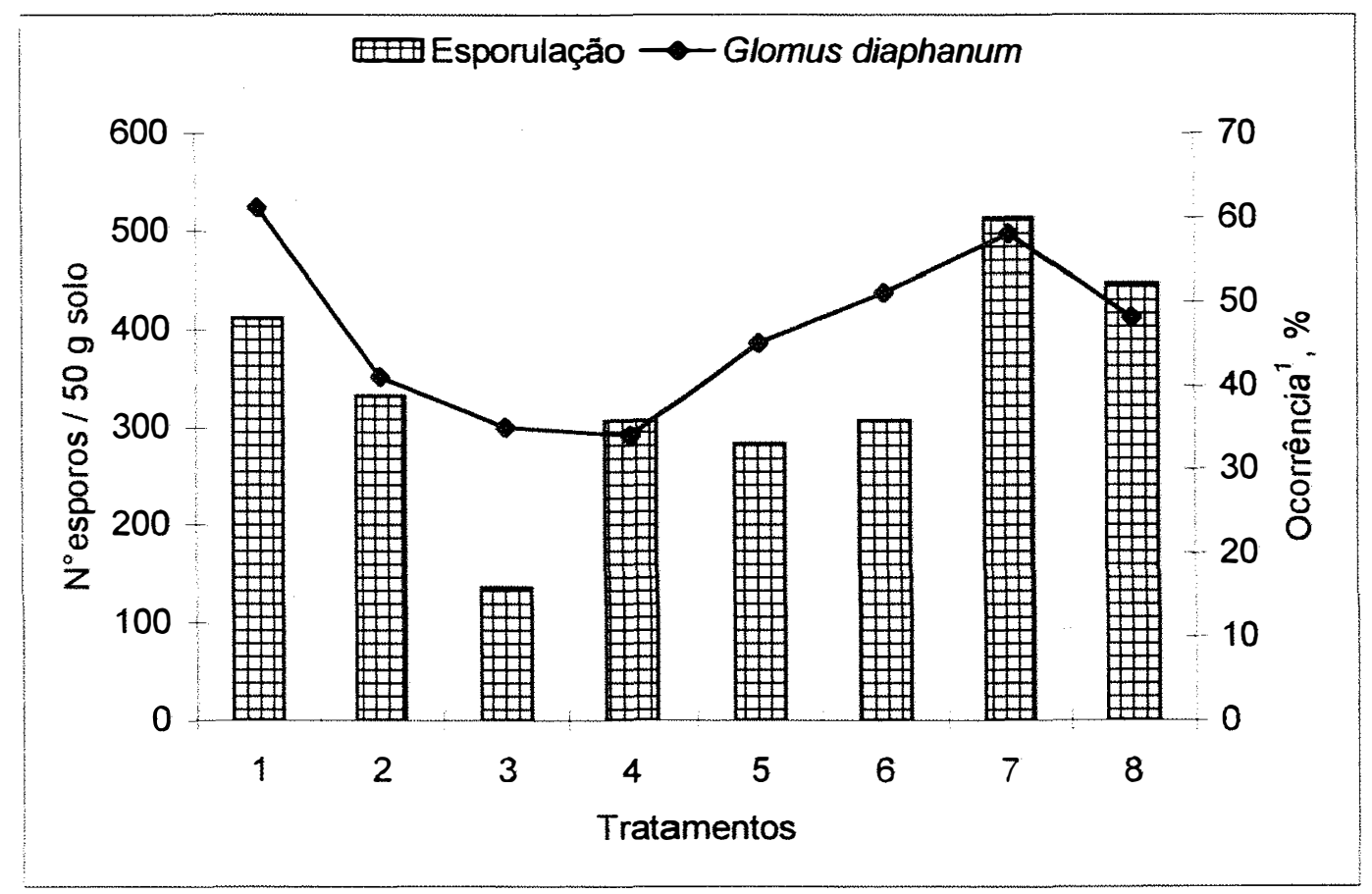

Figura 3. Esporulação de fungos micorrízicos arbusculares na rizosfera de milho e sorgo em casa de vegetação e ocorrência de Glomus diaphanum a campo. 1 a 7 referem-se ao cafeeiro cultivado a campo com as leguminosas Leucena, Crotalaria spectabilis. C. breviflora, Mucuna cinzenta, M. anã. Amendoim cavalo e Caupi na entrelinha, respectivamente. 8 corresponde ao cafeeiro cultivado na ausência de leguminosas (Controle). Média de 3 repetições. $1=$ Número de esporos da espécie pelo total de esporos observados na amostra. 
e tratamentos avaliados e o grande número de esporos produzidos mostraram sua alta adaptabilidade ao ambiente e agressividade em colonizar as plantas.

Para investigar a possibilidade de que variáveis de solo ( $\mathrm{P}$ disponível, $\mathrm{pH}$ ) estivessem atuando sobre a não colonização do cafeeiro por Gigasporaceae, em casa de vegetação cultivou-se o cafeeiro em solo coletado na linha de plantio das leguminosas a campo. Os resultados mostraram ocorrência e frequência de ocorrência de Gigasporaceae menor quando se cultivou cafeeiro no solo original em que foram observadas (Tabela 5). No mesmo solo onde se observou $100 \%$ de freqüência de ocorrência de S.gilmorei quando cultivado com leguminosas a campo (Tabela 3), se observou no máximo $25 \%$ de ocorrência deste mesmo fungo após o cultivo do cafeeiro (Tabela 5B). Também S. heterogama e Gi. decipiens, de ocorrência baixa no campo, não foram mais recuperadas. Por outro lado, observou-se grande freqüência de ocorrência de G.diaphanum, que mais uma vez confirma sua condição de oportunista agressivo, capaz de se estabelecer em situações de solo e hospedeiro variadas, estressantes para a maioria dos outros fungos MA. Quando se cultivou o cafeeiro em solo proveniente de áreas cultivadas com cafeeiro, A.scrobiculata, A.longula e G.diaphanum apresentaram maior freqüência de ocorrência, concordando com os resultados obtidos no campo (Tabela 3). Espécies de menor freqüência de ocorrência no campo como S.heterogama. A.appendicula, A.spinosa não foram mais recuperadas

A colonização radicular e a esporulação foram maiores em cafeeiros cultivados em solo proveniente da linha de plantio das leguminosas a campo, sendo este efeito maior para C.breviflora e M.anã. respectivamente (Tabela 6). Em cafeeiros cultivados em solo de café, a colonização radicular não diferiu e a esporulação foi maior quando se cultivou C.breviflora na entrelinha (Tabela 6), o que concorda com os dados obtidos no campo (Tabela 2). 
Tabela 5. Ocorrência e freqüência de ocorrência de fungos micorrízicos arbusculares em cafeeiro (Coffea arabica L.) cultivado em casa de vegetação em A): solo proveniente de experimento a campo, coletado na projeção da copa de cafeeiro cultivado com adubos verdes e B): solo proveniente da linha de cultivo dos adubos verdes. Média de 3 repetições.

\begin{tabular}{|c|c|c|c|c|c|c|c|c|}
\hline \multirow{2}{*}{$\begin{array}{l}\text { Ocorrência } \\
\text { de } \\
\text { espécies }\end{array}$} & \multicolumn{8}{|c|}{$\begin{array}{c}\text { Freqüência de ocorrência }{ }^{2}, \% \\
\text { Tratamentos }\end{array}$} \\
\hline & 1 & 2 & 3 & 4 & 5 & 6 & 7 & 8 \\
\hline \multicolumn{9}{|c|}{ A - solo da projeção da copa do cafeeiro. } \\
\hline Scutellospora gilmorei & & & 5,7 & & & 33 & 6 & \\
\hline S. pellucida & & 7 & & & & & 4,5 & \\
\hline Gigaspora decipiens & & & 1,5 & & & & & \\
\hline Acaulospora scrobiculata & 40 & 50 & 40 & 54 & 37,5 & 40 & 64 & 20 \\
\hline A.longula & 24,4 & 7 & 18 & 19 & 17 & & 1,5 & 20 \\
\hline Acaulospora sp. & & & & & & & 4,5 & \\
\hline Glomus sp. & & & 1,5 & & 4,2 & & 3 & \\
\hline G.diaphanum & 28 & 19,6 & 24 & 8 & 29 & 27 & 16 & 60 \\
\hline Não identificado & 7,3 & 8.9 & 9 & 19 & 12.5 & & & \\
\hline \multicolumn{9}{|c|}{ B - solo da linha de cultivo das leguminosas. } \\
\hline Scutellospora gilmorei & 0,9 & 9,5 & 6.5 & 25 & 9,7 & 18 & 11,8 & 14,3 \\
\hline S. pellucida & 3,8 & & & & 0,6 & 1,4 & 1,5 & 1,3 \\
\hline Gigaspora margarita & & & & & 1,3 & 1,4 & & 1,3 \\
\hline Acaulospora scrobiculata & 18,9 & 14,6 & 11 & 13 & 19 & 2,8 & 11,8 & 11,7 \\
\hline A.longula & 19,8 & & & & 1.9 & 1,4 & 4,4 & 15,6 \\
\hline Glomus sp. & & & & & 6,4 & & & \\
\hline G.diaphanum & 47 & 63 & 65 & 52 & 52 & 68 & 52,9 & 49 \\
\hline Não identificado & 9,4 & 12,9 & 17,4 & 10 & 9 & 6,9 & 17,6 & 6,5 \\
\hline
\end{tabular}

1. Ocorrência $=$ presença no tratamento; 2 . Freqüência de ocorrência $=\%$ de ocorrência da espécie no total de amostras avaliadas; 1 a 7 referem-se aos tratamentos onde se cultiva o cafeeiro com as leguminosas Leucena. Crotalaria spectabilis. C. breviflora. Mucuna cinzenta, M. anã, Amendoim cavalo e Caupi na entrelinha, respectivamente. 8 (Controle) corresponde ao cafeeiro cultivado na ausência de leguminosas. 
Tabela 6. Esporulação e colonização radicular de fungos micorrízicos arbusculares em cafeeiro (Coffea arabica L.) cultivado em casa de vegetação em A): solo proveniente de experimento a campo, coletado na projeção da copa de cafeeiro cultivado com adubos verdes e B): solo do campo proveniente da linha de cultivo dos adubos verdes. Média de 3 repetições.

\begin{tabular}{ccccc}
\hline Leguminosas & \multicolumn{2}{c}{${\text { Esporos, } \mathrm{n}^{\circ} .50 \mathrm{~g} \mathrm{de} \mathrm{solo}}^{-1}$} & \multicolumn{2}{c}{ Colonização, \% } \\
\cline { 2 - 5 } & $\mathrm{A}$ & $\mathrm{B}$ & $\mathrm{A}$ & $\mathrm{B}$ \\
\hline Leucena & $26 \mathrm{ab}(15 \mathrm{r}$ & $34 \mathrm{ab}$ & $23 \mathrm{a}$ & $58 \mathrm{a}$ \\
Crotalaria spectabilis & $28 \mathrm{ab}$ & $38 \mathrm{ab}$ & $33 \mathrm{a}$ & $37 \mathrm{~b}$ \\
C. breviflora & $34 \mathrm{a}$ & $32 \mathrm{ab}$ & $22 \mathrm{a}$ & $51 \mathrm{a}$ \\
Mucuna cinzenta. & $7 \mathrm{c}$ & $38 \mathrm{ab}$ & $22 \mathrm{a}$ & $29 \mathrm{bc}$ \\
M. anã & $19 \mathrm{~b}$ & $51 \mathrm{a}$ & $24 \mathrm{a}$ & $24 \mathrm{c}$ \\
Amendoim cavalo & $5 \mathrm{c}$ & $22 \mathrm{~b}$ & $25 \mathrm{a}$ & $31 \mathrm{bc}$ \\
Caupi & $21 \mathrm{ab}$ & $42 \mathrm{ab}$ & $27 \mathrm{a}$ & $36 \mathrm{bc}$ \\
Controle & $3 \mathrm{~d}$ & $25 \mathrm{~b}$ & $27 \mathrm{a}$ & $30 \mathrm{bc}$ \\
\hline C.V. \% & 9,5 & 9,5 & 13,7 & 8,8
\end{tabular}

1.Médias seguidas de mesma letra na coluna não diferem entre si pelo teste de Duncan a $5 \%$ de probabilidade.

\subsection{Discussão}

O cultivo de plantas diferentes em uma mesma área, na forma de pré-cultivo, rotação e/ou associação de culturas ou cultivo intercalar, pode aumentar a diversidade de espécies e o inóculo de fungos micorrízicos arbusculares do solo, aumentando seu potencial (Dood et al., 1990a: Baltruschat \& Dehne. 1988; Gomes-da-Costa, 1993). Neste trabalho relata-se o aumento da diversidade de espécies e do número de esporos de fungos MA na rizosfera do cafeeiro, quando cultivado com leguminosas de verão na entrelinha para adubação verde. Crotalaria breviflora mostrou-se altamente micorrízica, capaz de formar simbiose com várias espécies de fungos micorrízicos, o que resultou em 
maior diversidade de espécies e número de esporos de fungos MA no solo, em todas as épocas avaliadas. Este efeito foi observado também na rizosfera do cafeeiro cultivado ao lado. Entretanto, parte dos fungos presentes na rizosfera do cafeeiro não foram recuperados na rizosfera de milho e sorgo quando se utilizou raízes colonizadas como inóculo, evidenciando que parte da diversidade de espécies e concentração de esporos observada na rizosfera do cafeeiro são provenientes de raízes de leguminosas que crescem sob a projeção da copa do cafeeiro. Estes resultados sugerem também a ocorrência de relações preferenciais entre fungos e hospedeiro. Estas relações são importantes e podem determinar o estabelecimento e a eficiência da simbiose e a exclusão de algumas espécies do sistema radicular da plantas. A ocorrência de relações prefernciais entre fungo e hospedeiro, associadas às variações no número de esporos e no potencial de inóculo. precisam ser conhecidas quando se pensa em manejo como alternativa para aumentar o efeito biofertilizante das micorrizas.

Segundo Abbott \& Robson (1991), esporos são estruturas de resistência e de propagação dos fungos MA e juntamente com outras estruturas produzidas externamente às raizes (micélio e células auxiliares) e fragmentos de raízes colonizadas e hifas nas raízes e no solo compõem o inóculo do solo. A infectividade destes propágulos determina o potencial de inóculo do solo. Entretanto. não se conhece relação quantitativa entre os componentes do inóculo do solo e sabe-se que sua infectividade é bastante variável. Considerando-se os esporos como parte do inóculo natural do solo e analisando seu comportamento na rizosfera do cefeeiro em função do cultivo de adubos verdes, observou-se aumento no número de esporos na rizosfera e portanto é possível que tenha ocorrido aumento no potencial de inóculo natural do solo. O número médio de esporos recuperados no cafeeiro cultivado sem adubos verdes foi de 63 esporos em $50 \mathrm{~g}$ de solos, o que concorda com dados de esporulação em cafeeiro obtidos a campo por Balota \& Lopes (1996a) e Siqueira et al. (1989). Nas parcelas em que C.breviflora foi cultivada na entrelinha, o número médio de esporos foi de 99 em $50 \mathrm{~g}$ de solos, correspondendo a um aumento de $64 \%$.

A produção de esporos no solo é possivelmente uma resposta do fungo a mudanças fisiológicas ocorridas na planta hospedeira. e pode estar relacionada à 
diminuição no fluxo de carboidratos solúveis das raízes para o micélio, que ocorre no final do ciclo da planta. $\mathrm{E}$ a intensidade da esporulação depende da espécie de fungo MA e da capacidade da planta hospedeira em fornecer carboidratos ao fungo (Douds \& Schenck, 1990). Leguminosas tropicais possuem elevada capacidade fotossintética e independente da disponibilidade de nutrientes no solo são capazes de disponibilizar grandes quantidades de compostos assimilados para a microbiota (Graham \& Eissenstat, 1994). Além disso, leguminosas tem sido citadas como plantas altamente micorrízicas (Cardoso, 1985; Herrera et al., 1984) podendo portanto influenciar a ocorrência dos fungos MA. Entretanto, a maneira como isto acontece não é conhecida. A maior diversidade de espécies e concentração de esporos no solo observada nas leguminosas pode ser pela produção de metabólitos secundários como por exemplo compostos aromáticos biológicamente ativos como os flavonóides (Siqueira et al. 1991) que tem capacidade de estimular ou inibir populações de fungos MA na rizosfera, atuando sobre sua ocorrência e distribuição. È possível também que, com ciclo médio de 120 dias e dinâmica de ciclagem rápida, compostos liberados pelas crotalárias estimulem os fungos a produzirem mais esporos no solo e garantirem sua sobrevivência até o verão seguinte.

Dados de campo sugerem que a dinâmica da esporulação esta relacionada aos processos de desenvolvimento fisiológico da planta. No verão (Fev.96), época de maior crescimento vegetativo das culturas, a esporulação no solo foi menor. Ao final do ciclo das leguminosas ou após o florescimento do cafeeiro, o número de esporos recuperados no solo foi maior. Estes resultados concordam com os de Balota (1989), que observou número de esporos crescente no cafeeiro a partir de março/abril, atingindo valores máximos em setembro/outubro .Também Smith (1980), estudando o efeito de épocas e de rotação de culturas sobre a esporulação de fungos MA relatou maior número de esporos recuperados da rizosfera de trigo ao final do ciclo da cultura, na maturação do hospedeiro.

Embora não existam evidências consistentes que relacionem colonização e esporulação em FMA é necessário que haja um mínimo de colonização para que a esporulação ocorra. Frankie \& Morton (1994) citaram como condição para esporulação de Acaulospora e Scutellospora, colonização de no mínimo três vezes o comprimento 
radicular. Neste trabalho observou-se que as maiores esporulações ocorreram em períodos de maior colonização radicular (junho e julho), no cafeeiro e nas leguminosas.

A colonização radicular tem sido freqüentemente relacionada com $\mathrm{pH}$ e concentração de nutrientes no solo (Koide \& Li, 1990; Siqueira \& Saggin Júnior, 1995). Acidez e baixa concentração de nutrientes no solo correlacionam-se positivamente com a colonização radicular, indicando que o fungo, ao mesmo tempo em que favorece o crescimento das plantas, aumenta sua atividade metabólica nas raízes. Entretanto, em situações de maior disponibilidade de nutrientes as plantas tendem a dificultar a colonização, para não perder carboidratos drenados pelos fungos (Graham \& Eissenstat, 1994) que podem chegar a 39\% do total do produto da fotossíntese (Peng et al., 1993). Mas algumas plantas têm a habilidade ou a necessidade de manterem alta colonização radicular mesmo em situação de elevada fertilidade do solo (Porter et. Al., 1987; Bethlenfalvay et al., 1983), por serem micotróficas obrigatórias e possuírem algum tipo de deficiência de natureza fisiológica ou mesmo morfológica (Janos, 1988; Manjunath \& Habte, 1990; Koide, 1991; Smith et al., 1994). Por outro lado, alguns fungos tem habilidade de se associarem às raízes indiscriminadamente, produzindo efeitos que variam de neutros a negativos para as plantas, sendo por isso denominados oportunistas ou comensalistas (Peng et al.. 1993).

Neste trabalho observaram-se altas taxas de colonização no cafeeiro $(70 \%$ em julho) crescendo em substrato com alta concentração de $\mathrm{P}$ disponível $\left(28 \mathrm{mg} \cdot \mathrm{dm}^{-3}\right)$ e também grande esporulação de G.diaphanum quando se cultivou milho e sorgo, inoculados com raizes de cafeeiro provenientes do campo. em solo coletado na linha de plantio das leguminosas. Portanto, acredita-se que neste experimento possa estar ocorrendo tanto a colonização facilitada pelo cafeeiro quanto a multiplicação indiscriminada do oportunista G.diaphanum, pela sua elevada freqüência de ocorrência e representatividade nas amostras. Entretanto, com a metodologia utilizada neste trabalho não foi possivel identificar a origem da colonização radicular do cafeeiro.

Não se observaram diferenças na ocorrência de espécies de fungos MA entre a rizosfera do cafeeiro e das leguminosas cultivadas na entrelinha. Nestas plantas foram identificadas 12 espécies de fungos MA. No cafeeiro crescendo sem adubação verde e 
na parcela não cultivada somente 10 espécies foram recuperadas. Segundo Saggin Júnior \& Siqueira (1996), em levantamentos feitos em lavouras cafeeiras no sudeste brasileiro já foram identificadas 45 espécies de Glomales, sendo 12 do gênero Acaulospora, 17 Glomus, 6 Scutellospora, 4 Sclerocystis e 2 Entrophospora, além de várias espécies não descritas. Neste trabalho identificou-se Scutellospora gilmorei, Spellucida, Sheterogama, Gigaspora margarita, Gi.decipiens, Acaulospora scrobiculata. A.appendícula, A.longula, A.spinosa, Acaulospora sp., Glomus sp. e G.diaphanum.

A freqüência de ocorrência de espécies, analisada a campo e em casa de vegetação mostrou que na rizosfera do cafeeiro foram estimuladas populações diferentes daquelas encontradas com maior freqüência nas leguminosas. Esporos de A.longula e G.diaphanum ocorreram com $100 \%$ de freqüência em cafeeiro enquanto que S.gilmorei e A.scrobiculata foram as mais freqüentes (100\%) nas leguminosas. Fernandes (1987) e Balota \& Lopes (1996b) também relataram maior ocorrência de Acaulospora e Glomus em cafeeiros a campo. Ainda segundo Fernandes (1987), o índice de ocorrência de Gigaspora e Scutellospora em lavouras do sudeste brasileiro foi de aproximadamente 15 e $12 \%$ respectivamente, bem inferior ao índice de ocorrência de Acaulosporas (100\%). De maneira geral, na rizosfera do cafeeiro predominaram Acaulosporaceae, enquanto que na rizosfera das leguminosas predominaram as Gigasporaceae. Entretanto, em vasos de cultivo em casa de vegetação utilizando como inóculo raízes de cafeeiro cultivados no campo. nenhuma Gigasporaceae foi recuperada. Foram multiplicadas A.scrobiculata. A.longula, Glomus sp. e G.diaphanum, sendo o último os mais freqüentes, seguido das Acaulosporas. Quando o inóculo foi raízes de leguminosas, foram recuperadas S.gilmorei, S.pellucida, S.heterogama, A.scrobiculata, A.longula, Glomus sp. e G. diaphanum, sendo a primeira e a última as mais freqüentes. Estes resultados mostraram que, apesar de ocorrerem na rizosfera do cafeeiro, as Gigasporaceae não estão colonizando suas raizes. Quando se cultivou o cafeeiro em solo previamente cultivado com leguminosas contendo varias espécies de Gigasporaceae, poucos esporos destes fungos foram recuperados sendo possível que alguns deles sejam ainda resultantes do cultivo anterior, porque se apresentavam velhos e parasitados. 
Gigaspora margarita, que tem sido citada como eficiente em aumentar o crescimento do cafeeiro (Lopes et al., 1983b; Antunes et al.. 1988, Colozzi Filho et al., 1985), foi encontrada na rizosfera das leguminosas e do cafeeiro, mas não foi recuperada quando se inoculou plantas hospedeiras com raízes de cafeeiro colonizadas, em nenhuma época avaliada. Também quando o cafeeiro foi cultivado no solo previamente cultivado com leguminosas, nenhuma esporulação evidente desta espécie foi observada, mas observou-se multiplicação de A.scrobiculata, A.longula e abundante esporulação de G.diaphanum.

Segundo Johnson et al. (1992), monoculturas prolongadas selecionam espécies de fungos MA mais adaptadas ao ecossistema, que nem sempre são as mais eficientes em promover os efeitos da micorrização. Neste trabalho observou-se a ocorrência de A.longula e A.scrobiculata com maior frequência no cafeeiro, e Gigasporaceae nas leguminosas. G.diaphanum se mostrou um oportunista agressivo e não específico, colonizando na mesma intensidade cafeeiro e leguminosas. Conforme relatado por Balota \& Lopes (1986b), populações de fungos MA podem se influenciar na rizosfera, de forma variada e dependente das condições de solo e planta. Os resultados obtidos neste experimento sugerem que G.diaphanum esteja influenciando negativamente a colonização do cafeeiro por Gigasporaceae mas este aspecto não foi investigado.

Portanto, espécies de fungos MA nativas altamente adaptadas ao ecossistema e que exibem relações preferenciais com as plantas podem estar atuando negativamente sobre a freqüência de ocorrência de outras espécies nativas mas menos adaptadas, diminuindo sua representatividade. É possível que a ocorrência de relações preferenciais entre fungo e hospedeiro seja um dos mecanismos através dos quais fungos são excluídos do sistema solo planta. 


\subsection{Conclusões}

- O cultivo de leguminosas aumentou a diversidade de fungos micorrízicos arbusculares e a concentração de esporos no solo.

- O cultivo de leguminosas para adubação verde na entrelinha do cafeeiro, aumentou a diversidade de espécies e o número de esporos de fungos micorrízicos arbusculares na rizosfera do cafeeiro.

- O Cafeeiro e as leguminosas estimularam populações de fungos micorrízicos diferentes na sua rizosfera. Acaulosporaceae foram mais freqüentes no cafeeiro e Gigasporeceae, principalmente Scutellospora gilmorei, nas leguminosas.

- Glomus diaphanum mostrou-se um oportunista agressivo e inespecífico.

Em bioensaios em casa de vegetação, Gigasporaceae não foram encontradas colonizando as raízes do cafeeiro.

- A adubação verde pode não ser eficiente em aumentar o efeito biofertilizante da micorrização, devido a ocorrência de relações preferencias entre fungo e hospedeiro. 


\section{METODOLOGIA SIMPLIFICADA PARA ISOLAMENTO DE DNA GENÔMICO DE UM ÚNICO ESPORO DE FUNGOS MICORRİZICOS ARBUSCULARES}

\subsection{Resumo}

O desenvolvimento de novas técnicas de biologia molecular tem facilitado a taxonomia e estudos ecológicos dos fungos micorrízicos arbusculares (MA) através da comparação de seu DNA genômico amplificado pela PCR (Polimerase chain reaction). Diversos pesquisadores tem utilizado a PCR para amplificar regiões ITS (Internal transcribed spacer) do DNA ribossomal destes fungos como uma técnica auxiliar para sua deteç̧ão e identificação no solo ou em simbiose com raízes em diferentes ecossistemas. Entretanto, os métodos para extração de DNA disponíveis são complicados e trabalhosos, de difícil aplicação quando se utiliza grande número de amostras. Neste trabalho relata-se um método simples e rápido para o isolamento de DNA genômico de um único esporo de fungos MA de diferentes gêneros. Com este método, o DNA genômico obtido foi de qualidade e em quantidade suficiente para a reação da PCR e a amplificação de fragmentos da região de ITS, usando os primers ITS 4 e 5. Este procedimento mostrou-se altamente reproduzivel. Fragmentos de PCR foram obtidos de 86 a $22 \%$ dos esporos estudados. comprovando a eficiência do método. Tamanhos de fragmentos de DNA idênticos e de mesma seqüência parcial de DNA foram obtidos de muitos dos esporos, previamente selecionados por critérios morfológicos. Portanto, acreditamos que este procedimento rápido e fácil é ideal para projetos que objetivam estudos de dinâmica da população de fungos MA no solo visto que permite o estudo de grande número de amostras. 


\subsection{Summary: A SIMPLE METHOD FOR ISOLATION OF GENOMIC DNA FROM A SINGLE SPORES OF ARBUSCULAR MYCORRHIZAL FUNGI.}

The development of new molecular techniques has facilitated taxonomic and ecological field studies of arbuscular-mycorrhizal fungi (AM) by comparison of amplified genomic DNA. Several researchers have been using PCR (Polimerase chain reaction) amplified ITS (Internal transcribed spacer) region of the ribosomal DNA as an auxilliary technique for identification of these fungi in the soil or in symbiosis in different ecosystems. Nevertheless, currently used methods for DNA extraction are very elaborate and thus difficult to apply with large sample numbers.

In this work, we thus report on a simple and quick method for isolation of genomic DNA from single spores of AM fungi of different genera. The obtained genomic DNA was of sufficient quality for PCR-amplification of the ITS-region using ITS 4 and 5 primers. The procedure was highly reproduceable. PCR fragments were obtained from 86 to $22 \%$ of the investigated spores revealing the efficiency of the method. Identical DNA-fragment sizes and partial DNA sequences were obtained from most spores preselected by morphological criteria. This easy and quick procedure is thus ideally suited for large scale projects dealing with population dynamics of AM fungi in soil.

\subsection{Introdução}

A associação simbiótica entre fungos micorrízicos arbusculares (MA) e raízes de plantas é comum na natureza. Os efeitos positivos da inoculação de fungos MA em sistemas de cultivo agrícolas têm sido intensivamente demonstrados e comprovados e incluem melhoria do estado nutricional e efeitos benéficos na regulação do crescimento de plantas, redução nos efeitos provocados em plantas por estresses de natureza biótica (pragas e doenças) ou abiótica (déficit hídrico, nutricional ou térmico) e também melhor utilização e conservação dos nutrientes no sistema solo-planta. 
Entretanto, a utilização destes fungos a nível comercial e também a realização de estudos mais aprofundados sobre fisiologia e bioquímica do simbionte e da simbiose tem sido dificultados devido a impossibilidade de cultivo destes microrganismos em sistemas artificiais (in-vitro), na ausência de raízes vivas. Esporos assexuados produzidos no solo são a principal fonte de inóculo e também a base para descrição taxonômica das aproximadamente 130 espécies identificadas (Morton \& Benny, 1990). Atualmente, a identificação baseia-se em características morfológicas e estruturais dos esporos, que consome muito tempo e muitas vezes não é possível porque estas características podem ser influenciadas por condições ambientais ou mesmo por diferentes fases de maturidade dos esporos (Morton \& Bentivenga, 1994).

O desenvolvimento de novas e avançadas técnicas de biologia molecular tem possibilitado estudos taxonômicos de fungos MA através da comparação de seu DNA genômico. A introdução e aplicação da técnica de amplificação do DNA por PCR (Polymerase chain reaction) White et al. (1990) reduziu a quantidade de DNA isolado necessária para estudos genéticos, permitindo que organismos de difícil multiplicação e obtenção de DNA como os fungos MA pudessem ser estudados. A partir daí, diversos pesquisadores tem utilizado a PCR como técnica auxiliar para identificação destes fungos no solo (Gardes \& Bruns, 1993; Lanfranco et al., 1993; Henrion et al., 1992: Egger \& Fortin, 1990) ou mesmo quando em simbiose colonizando as raízes ( Simon et al., 1992; Bonito et al.. 1995), em diferentes ecossistemas.

A partir da $\mathrm{PCR}$, dentre várias técnicas, a utilização de primers específicos que permitem a amplificação de fragmentos de DNA obtidos a partir da região ITS (Internal transcribed spacer) tem sido usada para estudar as relações filogenéticas entre grupos de fungos. Os primers universais ITS1 e ITS4 amplificam o gene 5.8S rRNA e duas regiões de ITS que flanqueiam este gene (White et al., 1990). O gene $5.8 \mathrm{~S}$ é altamente conservado e tem possibilitado que a análise das seqüências da região ITS seja usada com sucesso para a identificação de relações filogenéticas entre fungos ectomicorrízicos (Gardes \& Bruns. 1993: Bruns \& Gardes. 1993; Gardes et al., 1991). A região ITS de Pleurotus tem uma taxa de substituição genética sete vezes maior que aquela da maior sub-unidade rRNA, e revelou variação genética entre isolados de diferentes localidades 
geográficas. Para fungos MA, recentemente Sanders et al. (1995) relataram a observação de três seqüências de ITS em um único esporo de Glomus mosseae. Lloyd-Macgilp et al. (1996) confirmaram a ocorrência de seqüências heterogêneas de ITS em um mesmo esporo de fungo MA e não encontraram relações claras entre esta divergência genética e a morfologia dos esporos. Por outro lado, Zeze et al. (1996) publicou seqüências para Scutellospora castanea e tem descrito primers específicos para detecção destes fungos em raízes colonizadas.

Diante das dificuldades e potencialidades que a técnica da PCR representa para o estudo dos fungos MA, é importante o desenvolvimento ou adaptação de metodologias que facilitem o trabalho e tornem os resultados mais precisos. Nós utilizamos a maioria dos protocolos para extração de DNA de esporos publicados e observamos que são complexos, envolvendo a execução de diferentes procedimentos de centrifugação e ou aquecimento, utilizando diferentes soluções para extração tais como Tris $\mathrm{Cl}^{-} \mathrm{pH} 8.0$ (Sanders et al., 1995), tampão de extração CTAB ( Lloyd-Macgilp et al., 1996) e Chelex para a retirada de íons da solução (Wyss \& Bonfante, 1993; Harney et al., 1997). Também a quantidade de esporos utilizada para extração do DNA nos trabalhos publicados varia de 1 único esporo ou de grupos de 5 a 10 esporos (Wyss \& Bonfante, 1993) para 10 esporos (Harney et al., 1997) ou até grupos de 20 a 60 esporos (Simon et al., 1992).

Neste trabalho relata-se o isolamento e amplificação com primers ITS de DNA de um único esporo de espécies de diferentes gêneros de fungos MA, a partir de uma metodologia simples, rápida e eficiente de extração. considerando que o DNA extraído de um único esporo pode permitir estudos de variações intra-específicas e também que, quanto mais simples e eficiente for o protocolo, maior será o rendimento do trabalho e menores serão as interferências sobre a amplificação e sequenciamento. 


\subsection{Material e Métodos}

\subsubsection{Os esporos de fungos MA}

Utilizaram-se esporos de Acaulospora sp. provenientes da rizosfera de cafeeiros (Coffea arabica L.), Scutellospora sp. da rizosfera de Crotalaria breviflora e Glomus sp. e Entrophospora sp. provenientes da rizosfera de araucária (Araucaria angustifolia [Bert.] O. Ktze). Para as coletas de esporos no cafeeiro e leguminosas utilizou-se um experimento instalado no campo e conduzido a 10 anos pelo Instituto Agronômico do Paraná, em Mirasselva, PR. Os esporos provenientes da Araucária foram coletados na rizosfera de plantas cultivadas em substrato misto contendo solo e matéria orgânica (1:1 vol:vol) e conduzidos a 12 meses em casa de vegetação do Instituto de Botânica da Eberhard-Karls-Universität, em Tübingen, Alemanha. A campo, os esporos foram extraídos de amostras de solo compostas coletadas a profundidade de 0 a $20 \mathrm{~cm}$ sob a projeção da copa do cafeeiro e da Crotalária. O solo inóculo foi seco ao ar e armazenado em sacos plásticos em câmara fria $\left(6^{\circ} \mathrm{C}\right)$ até sua utilização. Em casa de vegetação os esporos foram obtidos de amostras de substrato coletadas diretamente no vaso de cultivo. Os esporos foram extraídos do solo por peneiramento úmido, conforme Gerdemann \& Nícolson (1963) e centrifugados em água a $300 \mathrm{rpm}$ por $3 \mathrm{~min}$ e em sacarose $50 \%$ a $2000 \mathrm{rpm}$ por $2 \mathrm{~min}$. Após a extração os esporos foram lavados por quatro vezes em água destilada estéril e então submetidos ao ultra-som por trinta segundos, na potência máxima, para eliminar esporos velhos e também partículas de solo e microrganismos contaminantes aderidos superficialmente aos esporos. Para eliminar os debris resultantes da sonicação, os esporos são novamente lavados por quatro vezes em água destilada estéril e então selecionados morfologicamente. Os esporos foram selecionados baseando-se em critérios como cor, tamanho, forma, conteúdo visível e forma da hifa de sustentação, de modo que aqueles de aparência similar formassem um grupo. Através deste critério foram selecionados esporos de Scutellospora sp, Glomus sp, Entrophospora sp. e Acaulospora sp. A escolha destes gêneros foi em função da maior disponibilidade de esporos no solo. 
Observações sobre a morfologia externa dos esporos foram feitas em microscópio estereoscópio (aumento de 80x) com luz refletida. Somente esporos de forma globosa, de aparência saudável e com vacúolos visíveis foram selecionados dentro do mesmo grupo de esporos. Estes critérios puderam ajudar na seleção de esporos uma vez que são facilmente observáveis nestas espécies, mas podem não ser aplicáveis a outras espécies como por exemplo algumas scutellosporas de coloração escura. Esporos de forma irregular e com características diferentes foram eliminados.

\subsubsection{Extração, amplificação e sequenciamento do DNA}

Para a extração do DNA, utilizou-se um único esporo para um volume final de reação de $50 \mu$ l. Com o auxilio de uma pinça de ponta ultra fina e sob microscópio estereoscópio de luz refletida, os esporos foram coletados individualmente e transferidos para $5 \mu \mathrm{l}$ de água estéril (Figura 1).

Figura 1. Esporo de Scutellospora sp sendo transferido para o mix da PCR com pinça de ponta ultra fina (Aumento de 20x). 
Uma vez transferidos, foram então cuidadosamente quebrados com as pontas da pinça, garantindo a liberação de seu conteúdo na água, compondo então o extrato cru. Este extrato contendo $5 \mu \mathrm{l}$ de água mais o protoplasma fúngico e pedaços de parede dos esporos foi então rapidamente coletado e colocado em tubos de microcentrífuga contendo o mix para a reação de PCR, completando o volume final da reação $50 \mu$ l. Nenhum tratamento ou procedimento adicional foi aplicado ao extrato cru ou a reação até esta ser colocada no termociclador para amplificação. Todo material utilizado para o manuseio dos esporos foi esterilizado. A água para obtenção do extrato cru deve ser bidestilada estéril.

A reação da PCR consistiu de $125 \mu \mathrm{M}$ de cada dNTP. 20 pmol de cada primer. 7,5 $\mathrm{mM} \mathrm{MgCl}$, 1,5 unidades de Taq polymerase Goldstar (Eurogentec, Seraing, Belgica) sendo o tampão fornecido com a enzima e usado nas concentrações conforme as indicações do fabricante. Os primers ITS 4 (5 $5^{`}$-TCCTCCGCTTATTGATATGC-3`) e ITS 5 (5`-GGAAGTAAAAGTCGTAACAAGG-3`) 8MWG-Biotech. Ebersberg. Alemanha) foram utilizados combinados.

O DNA ribossomal da região ITS foi amplificado usando um termociclador Perkin-Elmer System 2400 programado para $95^{\circ} \mathrm{C}$ por 3 minutos para desnaturação inicial. 40 ciclos de 1 minuto a $94^{\circ} \mathrm{C}$ para desnaturação, 40 segundos a $50^{\circ} \mathrm{C}$ para anelamento, 1 minuto a $72^{\circ} \mathrm{C}$ para extensão e 5 minutos a $72^{\circ} \mathrm{C}$ para extensão final. Em todos os experimentos foram usados tratamentos controle onde nenhum DNA foi colocado. Todos os tubos e materiais utilizados na composição das soluções e no manuseio dos esporos foram esterilizados.

Os produtos obtidos foram separados por eletroforese em gel de agarose $1.4 \%$. Os fragmentos de DNA resultantes foram visualizados através de coloração com brometo de etídeo e fotografados sob luz U.V.. Os produtos da PCR foram purificados usando o kit Quiagen para purificação (Quiagen. Hilden. Alemanha). Para subclonagem dos fragmentos da PCR foi usado o kit T-cloning (Promega, Madison, USA). O sequenciamento (Sanger et al., 1977) foi feito usando os primers ITS 4 e 5 e o kit para sequenciamento da Amersham (Branschweig, Alemanha), em sequenciador automático (ABI 373, Perkin Elmer, Forster City, USA). 


\subsection{Resultados}

Usando o protocolo descrito foi possível obter um estrato cru que contém DNA em quantidades suficientes e de qualidade para amplificação, através da PCR, de fragmentos de DNA da região ITS de um único esporo de fungos MA.

A ciclagem e as concentrações dos componentes usados na PCR foram otimizadas testando-se diferentes reagentes em diferentes concentrações e condições de incubação, inclusive Taq-polymerases de diversos fornecedores (dados não apresentados). Foram obtidos melhores resultados com a Taq-polymerase "Goldstar" sob as condições descritas no material e métodos.

Interferências na amplificação freqüentemente causadas pelo uso de EDTA, SDS e outras combinações de substâncias químicas utilizados para extração de DNA foram eliminadas por este procedimento.

DNA de esporos diferentes mas de mesma espécie de fungos MA (de acordo com critérios morfológicos) apresentaram fragmentos de ITS de tamanhos quase idênticos, após eletroforese do DNA amplificado (Figura 2).

Somente para Entrophospora sp., dois esporos em 10 originaram fragmentos de ITS de tamanhos diferentes. Algumas variações na intensidade das bandas produzidas (Figura 2) e na freqüência de amplificações de ITS de esporos (Tabela1) foram observadas.

Para Scutellospora sp., aproximadamente $81 \%$ dos esporos originaram fragmentos de ITS. A freqüência de amplificação destes fragmentos para Entrophospora sp., Glomus sp. e Acaulospora sp. foi de 86, 22, e 35\% respectivamente (Tabela 1).

Os produtos da amplificação da região ITS revelaram diferenças no peso molecular entre gêneros de fungos MA. DNA de Scutellospora sp. resultou em fragmentos de PCR de aproximadamente 540 bases pares (bp), Entrophospora sp. e Glomus sp. aproximadamente 580 bp e Acaulospora sp. aproximadamente 560 bp. (Figura 2). 

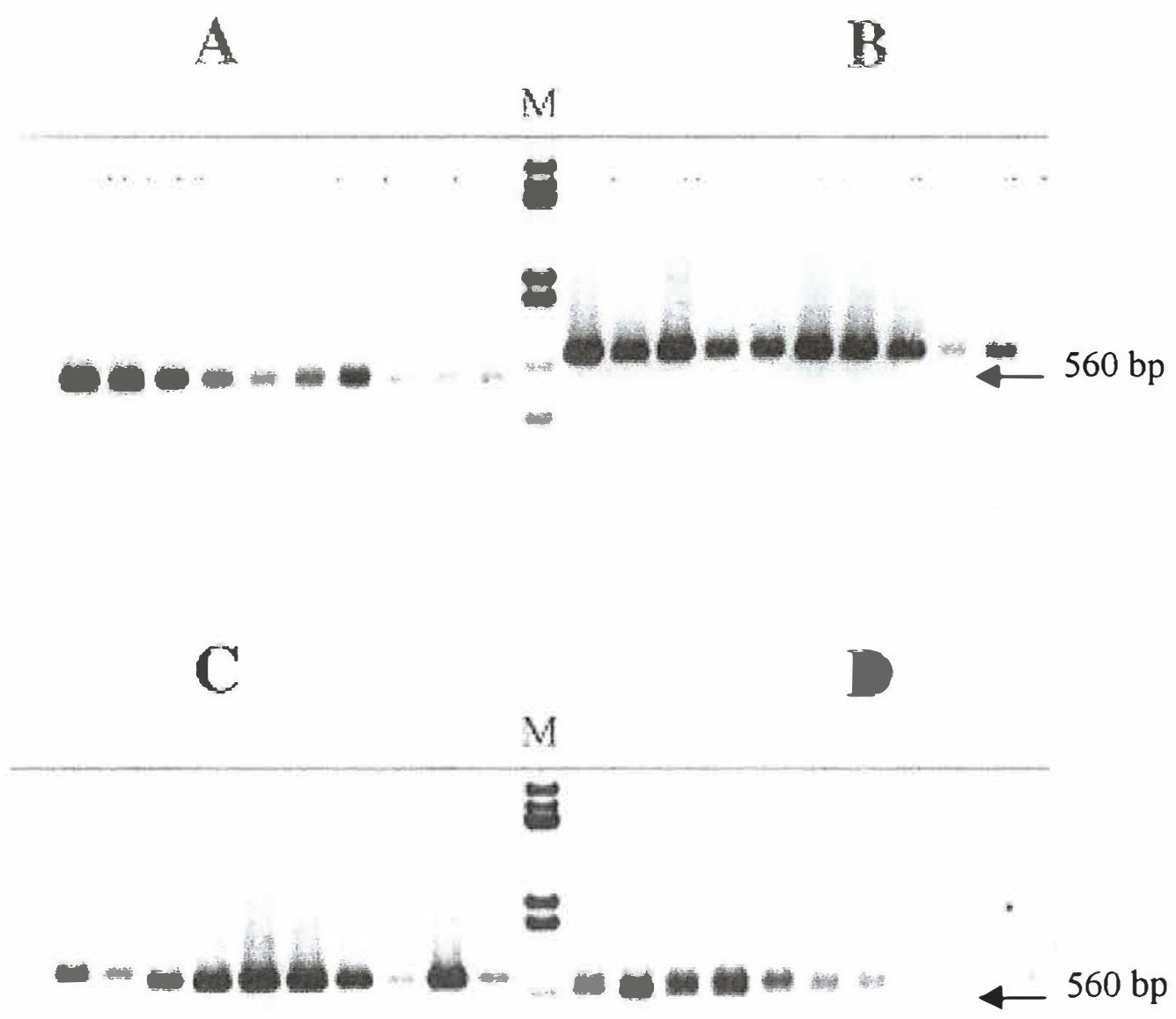

Figura 2. Produtos de amplificação de 10 PCRs obtidos a partir de extratos crus preparados de um único esporo de fungos micorrízicos arbusculares usando os primers de ITS 4 e 5 combinados. A = Scutellospora sp; B = Glomus sp ; $\mathrm{C}=$ Entrophospora $\mathrm{sp} ; \mathrm{D}=$ Acaulospora $\mathrm{sp} ; \mathrm{M}=$ marcadores (DNA de fago lambda digerido com HindIII e pBR322 digerido com MvaI).

A análise da seqüência dos fragmentos do DNA amplificado, obtida pelo sequenciamento direto dos fragmentos ou após subclonagem em um plasmidio vetor, e o alinhamento com seqüências de ITS conhecidas e registradas em bancos de dados, 
confirmaram a identificação morfológica dos gêneros de FMA estudados (dados não apresentados).

Tabela 1. Freqüência de obtenção de produtos da PCR de DNA de um único esporo de fungos micorrízicos arbusculares (FMA), usando os primers ITS 4 e 5 combinados.

\begin{tabular}{lccc}
\hline \multicolumn{1}{c}{ FMA } & Esporos, $\mathrm{n}^{\circ}$ & Amplificações positivas, $\mathrm{n}^{\circ}$ & Freqüência, \% \\
\hline Scutellospora sp. & 32 & 26 & 81 \\
Entrophospora sp. & 44 & 38 & 86 \\
Glomus sp. & 36 & 8 & 22 \\
Acaulospora sp. & 43 & 15 & 35 \\
\hline
\end{tabular}

\subsection{Discussão}

$\mathrm{O}$ estudo da dinâmica das populações de fungos MA é importante para o entendimento da simbiose endomicorrizica sob condições de campo.

Para contribuir com este estudo, métodos moleculares que possibilitam a identificação de espécies de FMA tem sido recentemente desenvolvidos. O ponto de partida foi o isolamento de DNA genômico de um único esporo ou grupos de 5 a 60 esporos (Simon et al., 1992; Wyss \& Bonfante, 1993; Harney et al., 1997). Entretanto, a extração de DNA consistia-se, até o presente momento, em um processo laborioso, que consumia muito tempo e trabalho, usando procedimentos de extração complexos e caros (Sanders et al., 1995; Lloyd-Macgilp et al., 1996; Wyss \& Bonfante, 1993; Hamey et al., 1997).

Neste trabalho descreve-se um método extremamente simples, rápido e eficiente para extração de DNA de um único esporo de Scutellospora sp., Acaulospora sp., Glomus sp. e Entrophospora sp., capaz de permitir a amplificação de regiões de ITS através da PCR. Este método elimina a necessidade de procedimentos de aquecimento, 
centrifugações e incubações em várias soluções como tem sido feito, sendo portanto ideal para estudos em larga escala de populações de FMA em campo.

Com este procedimento de extração de DNA observou-se diferenças na eficiência de amplificação de ITS entre espécies de FMA, produzindo-se fragmentos de PCR que variaram de $86 \%$ a $22 \%$ dos esporos investigados. Porém, não se observou correlação entre eficiência de amplificação e origem dos esporos. Para esporos isolados do campo (Scutellospora sp e Acaulospora sp), obtiveram-se taxas de amplificação de 81 e $35 \%$ respectivamente. Similarmente, de esporos obtidos de substratos em casa de vegetação (Entrophospora sp. e Glomus sp.) observou-se taxas de amplificação de 86 e $22 \%$, respectivamente.

Também diferenças no tamanho dos esporos e portanto no número de núcleos, não puderam explicar a diferente eficiência de amplificação de ITS entre Entrophospora sp. e Scutellospora sp., que, com tamanho de esporos significantemente diferentes, resultaram em rendimento de amplificação de ITS de aproximadamente $85 \%$. De acordo com Wyss \& Bonfante (1993), a quantidade de DNA de fungos MA requerida para amplificação normalmente é muito pequena (15 a 20 pg) e um único esporo destes fungos contem em média aproximadamente 1.5 a $2.0 \mathrm{ng}$ de DNA. Portanto, até mesmo os esporos de tamanho menor contêm DNA suficiente para a PCR, e não deveriam apresentar freqüências baixas de amplificações positivas.

Sobre a grande variação em eficiência de amplificação de regiões de ITS entre espécies (Tabelal) assume-se duas razões principais:

1) A variabilidade na viabilidade dos esporos de diferentes espécies de fungos MA no solo (isso não foi determinado antes da execução da PCR) ou

2) Inibidores contidos nos extratos de esporos. Fatores de solo tais como íons aderidos superficialmente aos esporos podem agir como inibidores da PCR, como sugerido por vários autores. Eles recomendam o uso de resinas para a eliminação de íons de solo presentes no extrato (Wyss \& Bonfante, 1993; Bonito et al., 1995). Porém, obteve-se taxas de amplificação excelentes e baixas no mesmo solo. sem a adição de resinas ou qualquer outro componente no extrato. Assim, provavelmente as baixas taxas de 
amplificação de regiões de ITS observadas para Glomus sp. e Acaulospora sp. estejam relacionadas a presença de inibidores espécie-dependentes internos.

O uso do ultra-som nos esporos por 30 segundos foi eficiente para livrar os esporos de partículas de solo e microorganismos aderidos superficialmente. Este procedimento é importante e necessário porque os esporos não foram superficialmente desinfestados antes de extração do DNA.

Soluções esterilizantes como Cloramina-T ou o antibiótico estreptomicina podem inibir a reação de PCR (Sanders et al., 1995) além de não serem suficientemente eficientes para eliminarem os BLO's (Bacterial like organisms) freqüentemente presentes no citoplasma de fungos MA (Scannerini \& Bonfante, 1991). Contaminantes de esporos tem sido citados como produtores de fragmentos de ITS de tamanhos diferentes dos observados em fungos MA (Sanders et al., 1995). A possibilidade que contaminantes produzam fragmentos de ITS do mesmo tamanho daqueles produzidos por fungos MA e que estes produtos de amplificação se confundam com os de fungos MA parece pouco provável uma vez que o DNA de possíveis contaminantes representa uma pequena parte do DNA total do esporo, tendo portanto menor possibilidade de amplificação. Nos experimentos descritos aqui, não se encontrou amplificações de DNA de contaminantes uma vez que nenhuma banda dupla foi observada nos géis. Além disso, a análise do sequenciamento de fragmentos de ITS do DNA amplificado e o alinhamento destes resultados com seqüências de ITS descritas em bancos de dados confirmaram a identificação morfológica dos FMA estudados.

Como outros autores (Sanders et al., 1995; Lloyd-Macgilp et al.. 1996), neste trabalho também se observou variabilidade genética na seqüência de ITS amplificada de um único esporo. Fragmentos de ITS amplificados de Scutellospora sp., por exemplo, precisaram ser subclonados para se obter uma seqüência clara.

Portanto, com a metodologia descrita neste trabalho pode-se. de maneira simples. auxiliar na identificação de fungos MA e acelerar os estudos de populações destes fungos em condições de campo, utilizando-se técnicas de biologia molecular. 


\subsection{Conclusões}

- A metodologia desenvolvida para extração de DNA de fungos micorrízicos arbusculares permite a extração de DNA de um único esporo, de forma rápida e de maneira simplificada.

- O DNA de fungos micorrízicos arbusculares obtido através da metodologia de extração desenvolvida neste trabalho é de qualidade e em quantidade suficiente para amplificação e sequenciamento.

- A eficiência da amplificação de fragmentos de DNA através da PCR varia em função da espécie de fungo micorrízico arbuscular. 


\section{OCORRÊNCIA DE FUNGOS MICORRÍZICOS ARBUSCULARES EM \\ CAFEEIRO (COFFEA ARABICA L.) CULTIVADO COM CROTALARIA BREVIFLORA NA ENTRELINHA E SUA DETECÇÃO EM RAÍZES ATRAVÉS \\ DA PCR}

\subsection{Resumo}

Avaliou-se a ocorrência e a frequência de ocorrência de fungos micorrizicos arbusculares (MA) no solo rizosférico e nas raizes de cafeeiro (Coffea arabica L.) e de Crotalaria breviflora cultivada na entrelinha como adubo verde. Amostras de solo rizosférico e raizes foram coletadas em julho de 1997, em parte de um experimento de longa duração conduzido a campo pelo Instituto Agronômico do Paraná-IAPAR, no município de Mirasselva, PR. O experimento esta instalado a 10 anos, em uma área de latossolo vermelho escuro distrófico (LEd) onde, nas linhas principais cultiva-se o cafeeiro 'Catuaí Amarelo' e nas entrelinhas as leguminosas Leucena (Leucaena leucocephala), Crotalaria spectabilis, C. breviflora, Mucuna cinzenta (Stizolobium pruriens), Mucuna anã (Stizolobium deeringianum), Amendoim cavalo (Arachis hipogeae) e Caupi (Vigna unguiculata), para fins de adubação verde. O delineamento experimental é de blocos ao acaso com 3 repetições. Para este trabalho utilizou-se somente o tratamento de adubação verde do cafeeiro com Crotalaria breviflora e o controle. Determinou-se a diversidade de espécies de fungos MA através da identificação morfológica dos esporos, a freqüência de ocorrência de populações de fungos MA através da contagem direta de esporos no solo e a colonização radicular. Para identificar os fungos MA em raizes do cafeeiro extraiu-se DNA de esporos coletados na rizosfera e de raízes de cafeeiro colonizadas. realizando-se a PCR (Polimerase chain reaction) com primers ITS (Internal transcribed spacer) e comparando os perfis das bandas obtidas.

O cultivo de Crotalaria breviflora na entrelinha do cafeeiro aumentou a concentração de esporos de fungos MA na rizosfera do cafeeiro. Cafeeiro e Crotalaria 
breviflora estimularam populações de fungos MA diferentes. Fungos MA dos gêneros Acaulospora predominaram na rizosfera do cafeeiro e Scutellospora e Gigaspora na rizosfera das leguminosas. Usando técnicas moleculares foi possível caracterizar fungos na rizosfera e nas raízes colonizadas do cafeeiro, o que pode auxiliar no estudo da dinâmica destes fungos a campo. O fungo micorrízico Scutellospora gilmorei, de ocorrência comum em cafeeiro e em Crotalaria breviflora, não foi encontrado colonizando as raízes do cafeeiro.

\subsection{Summary: OCCURRENCE OF ARBUSCULAR MYCORRHIZAL FUNGI IN COFFEE (COFFEA ARABICA L.) INTERCROPPED WITH CROTALARIA BREVIFLORA AND DETECTION OF THESE FUNGI IN ROOTS USING PCR}

The sporulation and occurrence of arbuscular mycorrhizal (AM) fungi was evaluated in the coffee trees (Coffea arabica L ) and Crotalaria breviflora rhizosphere and roots. Crotalaria breviflora is intercropped for green manure between rows of the coffee plants. Samples of rizosphere soil and roots were collected in July of 1997, in a long time experiment localized at the Instituto Agronômico do Paraná - IAPAR, in Mirasselva. PR. The AM diversity was determined through the morphologic identification of spores, the AM occurrence frequency by the direct counting of spores in the soil and the root colonization evaluated with the grid-line method using stained roots. To identify AM in coffee roots, DNA from spores collected in the rizosphere and from colonized coffee roots was extracted and used for PCR (Polimerase chain reaction) with ITS (Internal transcribed spacer) primers, comparing the obtained bands.

The legume intercropping cultivation increased the inoculum potential of arbuscular mycorrhizal fungi in the soil. Coffee plants and Crotalaria breviflora stimulated populations of different AM fungi in their rhizospheres. Scutellospora spp. and Gigaspora spp. were more abundant at the legume rizosphere. Acaulospora spp. occurred more often in coffee plant rhizospheres. Using molecular techniques, it was 
possible to characterize AM fungi in the rhizosphere and in the colonized roots of the coffee plants, which is of great help in the study of AM fungal dynamics in the field. Scutellospora gilmorei, of common occurrence in coffee plants and Crotalaria breviflora, was not found colonizing the roots of coffee plants.

\subsection{Introdução}

As micorrizas arbusculares (MA) são associações simbiotróficas entre fungos da ordem Glomales e raízes da maioria das plantas vasculares. As MA atuam como um complemento do sistema radicular da planta hospedeira, capaz de aumentar a absorção de $\mathrm{P}$ e outros nutrientes, promover a proteção das plantas contra patógenos e desencadear no hospedeiro diversos outros efeitos ainda não de todo compreendidos.

A simbiose micorrízica é particularmente importante para o cafeeiro porque este apresenta elevada dependência aos fungos MA na fase de produção de mudas (Siqueira \& Colozzi Filho, 1986). Entretanto, as informações sobre a ocorrência de fungos MA em cafeeiros adultos não inoculados e em produção, mostram a predominância de espécies indígenas de baixa eficiência simbiótica (Fernandes, 1987; Balota \& Lopes, 1996a). Espécies selecionadas eficientes normalmente não ocorrem no campo (Lopes et al. 1983a) e quando introduzidas via inoculação, têm dificuldade de permanecer no agrossistema (Balota \& Lopes, 1996a). Através do manejo das culturas é possível aumentar a diversidade de espécies e o potencial de inóculo natural do solo (Baltruschat \& Dehne, 1988), promovendo população de fungos MA diversificada no solo e maior sustentabilidade do agrossistema (Bethlenfalvay \& Linderman, 1992).

Leguminosas fixam nitrogênio, são micorrízicas e desenvolvem-se bem em solos com baixos teores de $\mathrm{P}$ (Cardoso. 1985: Herrera et al., 1984). O seu cultivo na entrelinha do cafeeiro para fins de adubação verde pode promover aumento na densidade de raízes por unidade de área. devido ao crescimento vigoroso de seu sistema radicular, o que estimula a micorrização, aumenta a diversidade de espécies de fungos MA e o potencial infectivo natural do solo. Esta prática de agricultura sustentável pode 
evitar que o monocultivo selecione espécies de fungos MA pouco eficientes, conforme citado por Johnson \& Pfleger (1992).

Entretanto, além de aumentar a diversidade de espécies e o potencial de inóculo natural, as leguminosas devem também ser capazes de introduzir no agrossistema espécies de fungos MA que sejam efetivas em colonizar e eficientes em promover os benefícios da micorrização no cafeeiro.

O estudo de ocorrência e dinâmica das populações de fungos MA no solo é um desafio devido à dificuldade de identificação destes fungos, tanto livres no solo como internamente às raizes. Estudos com culturas armadilha são dificeis de serem executados e muitas vezes fornecem resultados não conclusivos. Este desafio entretanto está sendo vencido com o auxílio de novas técnicas de biologia molecular. Estas técnicas tem permitido identificar fungos a partir de esporos coletados diretamente do campo e também identificar fungos MA colonizando raízes de plantas (Bonito et al., 1995)

Análises de fragmentos de restrição de DNA amplificados por PCR (Polimerase chain reaction) são uma ferramenta poderosa que permitem a detecção de moléculas de ácidos nucleicos específicos presentes em pequenas quantidades (Steffan \& Atlas, 1991) e tem sido aplicada com sucesso na identificação de fungos MA. O uso da PCR com primers que flanqueiam a região genômica do ITS (Internal transcribed spacer) (Redecker et al., 1997) ou mesmo primers específicos como os desenvolvidos para Glomus mosseae (Lanfranco et al., 1995) e para Scutellospora castanea (Zeze et al, 1996), tem permitido a identificação taxonômica destes fungos sem os problemas de variações nos caracteres morfológicos que dificultam a taxonomia tradicional. Estas técnicas também tem sido aplicadas como ferramentas auxiliares para a identificação de fungos MA internamente às raízes (Bonito et al., 1995; Edwards et al., 1997).

Neste trabalho estudou-se a composição das populações de fungos MA, sua esporulação e frequência de ocorrência na rizosfera do cafeeiro e da Crotalaria breviflora cultivada na entrelinha como adubo verde, e a colonização radicular do cafeeiro, utilizando-se metodologias tradicionais de identificação de espécies e também através da PCR com primers de ITS. 


\subsection{Material e Métodos}

Este estudo foi realizado em amostras de solo rizosférico e raízes de cafeeiro (Coffea arabica L.) e de Crotalaria breviflora, cultivados a campo, como parte de um experimento de longa duração que tem como objetivo estudar os efeitos do cultivo intercalar de adubos verdes sobre as propriedades do solo e a produtividade do cafeeiro.

Este experimento vem sendo conduzido desde 1988 pelo Instituto Agronômico do Paraná- IAPAR, no município de Mirasselva, PR, e está instalado em uma área de latossolo vermelho escuro distrófico (LEd) cujo solo apresentava as seguintes características químicas na época da amostragem:

\begin{tabular}{lccccccc}
\hline & $\mathrm{pH}$ & $\mathrm{C}$ & $\mathrm{P}$ & $\mathrm{K}$ & $\mathrm{Ca}$ & $\mathrm{Mg}$ & $\mathrm{Al}$ \\
\hline \multirow{3}{*}{ Cafeeiro } & 3,90 & 7,87 & 28,55 & 0,17 & 0,7 & 0,48 & 0,6 \\
Leguminosas & 5,11 & 7,97 & 4,8 & 0,21 & 1,9 & 1,14 & 0,0 \\
\hline
\end{tabular}

No experimento cultiva-se o cafeeiro 'Catuaí Amarelo' nas linhas principais e nas entrelinhas as leguminosas Leucena (Leucaena leucocephala), Crotalaria spectabilis. C. breviflora, Mucuna cinzenta (Stizolobium pruriens). Mucuna anã (Stizolobium deeringianum), Amendoim cavalo (Arachis hipogeae) e Caupi (Vigna unguiculata) para fins de adubação verde. Como controle cultiva-se o cafeeiro no limpo. O delineamento experimental é de blocos ao acaso com 3 repetições. $\mathrm{O}$ cafeeiro é cultivado no espaçamento $4,0 \times 2,0 \mathrm{~m}$ por cova de 2 plantas e cada parcela possui 32 covas ( 4 linhas de 8 covas), sendo as 8 plantas centrais a área útil da parcela. Para as leguminosas, a data de semeadura é na primeira quinzena de outubro e a densidade de sementes varia em função da espécie. Por ocasião da floração, que ocorre em épocas diferentes para cada espécie, as leguminosas são cortadas, deixando-se os resíduos amontoados na área para cobertura do solo e decomposição. No controle são feitas capinas manuais durante o ano. sempre que nescessário

Para as avaliações, em julho de 1997 coletaram-se amostras nos tratamentos: a) cafeeiro cultivado com Crotalaria breviflora como adubo verde na entrelinha; b) 
Controle (cafeeiro cultivado sem adubo verde na entrelinha) e também na linha de cultivo da leguminosa Crotalaria breviflora, cultivada como adubo verde para o cafeeiro.

Foram coletadas 3 amostras compostas por tratamento ( 4 sub-amostras por parcela), a uma profundidade de 0 a $20 \mathrm{~cm}$, contendo aproximadamente $1 \mathrm{~kg}$ de solo rizosférico e raízes. Para o cafeeiro, as sub-amostras foram coletadas em 4 pontos eqüidistantes sob a projeção da copa e orientados para as direções norte, sul, leste e oeste. Na Crotalaria breviflora as sub-amostras foram coletadas alternadas na linha de plantio.

Do material amostrado (solo e raízes), $100 \mathrm{~g}$ de solo foram utilizadas para análises químicas de rotina ( $\mathrm{pH}, \mathrm{C}, \mathrm{P}, \mathrm{K}, \mathrm{Ca}, \mathrm{Mg}$ e $\mathrm{Al})$ e $50 \mathrm{~g}$ de solo para determinações quantitativas (número de esporos) e qualitativas (diversidade de espécies) de fungos MA.

As raízes foram lavadas e coradas com azul de tripano para determinação da colonização radicular e extração de DNA.

\subsubsection{Esporos de fungos MA}

Os esporos foram extraídos do solo por peneiramento úmido, conforme Gerdemann \& Nicolson (1963) e centrifugados em água a $3000 \mathrm{rpm}$ por $3 \mathrm{~min}$ e em sacarose $50 \%$ a $2000 \mathrm{rpm}$ por $2 \mathrm{~min}$. Após a extração, estes foram lavados por quatro vezes em água destilada estéril e então submetidos ao ultra-som por trinta segundos, na potência máxima. para eliminar esporos velhos e também partículas de solo e microrganismos contaminantes aderidos superficialmente, sendo então novamente lavados por quatro vezes em água destilada estéril.

Para as determinações qualitativas (identificação de espécies) e quantitativas (contagem) os esporos foram fixados com PVL (Polivinil-alcool) em lâminas microscópicas e observados em microscópio óptico composto. A identificação das espécies foi feita baseando-se em critérios morfológicos. conforme Schenck \& Perez (1987) e Morton \& Beny (1990).

Para extração de DNA, esporos de Acaulospora longula e Scutellospora gilmorei, observados na rizosfera do cafeeiro, foram obtidos em uma nova extração e separados por espécie do restante da população de MA, sob microscópio estereoscópio 
(aumento de 80x) com luz refletida. Os esporos foram selecionados pela aparência externa, considerando-se a coloração uniforme, forma globosa regular e ausência de solo aderido externamente. Esporos com características discrepantes foram descartados.

O DNA foi extraído através da quebra de um único esporo em $5 \mu l$ de água estéril, garantindo a liberação de todo seu conteúdo na água para formação do extrato cru, que foi rapidamente colocado no mix para a reação de PCR, conforme detalhado no capítulo 4 desta tese.

\subsubsection{Raízes}

Raízes do cafeeiro foram separadas do solo rizosférico em água corrente e lavadas. Para a determinação da colonização radicular por fungos MA as raízes foram aquecidas a $60^{\circ} \mathrm{C}$ em $\mathrm{KOH} 10 \%$ por 10 minutos para clarificação; lavadas em água destilada 4 vezes, acidificadas com $\mathrm{HCl} 1 \%$ por 2 minutos e fervidas por 10 minutos em solução de glicerol-ácido + azul de tripano 0,05\% (Phillips \& Hayman, 1970). A determinação da percentagem de colonização radicular foi feita em microscópio, pelo método da placa quadriculada, segundo Giovannetti \& Mosse (1980).

Para extração do DNA de raízes do cafeeiro, coletaram-se $50 \mathrm{mg}$ de raízes colonizadas ou não nas amostras compostas representativas de cada repetição As raízes foram selecionados em microscópio composto, sendo a colonização evidenciada pela presença de arbúsculos e/ou vesículas coradas em azul de tripano. Na seleção procurouse .amostrar diferentes tipos de micélio interno (fino e grosso) ou mesmo a presença de vesículas. O DNA foi extraído segundo metodologia proposta por Bonito et al. (1995) onde, para a retirada de água as raízes foram centrifugadas a $12000 \mathrm{~g}$ durante $1 \mathrm{~min}$. e então maceradas em $800 \mu l$ de tampão de extração (Tris-HCl 1M, pH 8.5). Ao extrato foi adicionada a resina Chelex 100, a uma concentração final de $5 \%$ do volume do tampão de extração. A mistura foi homogeneizada em vórtex e então fervida em banhomaria por $15 \mathrm{~min}$. A resina e os fragmentos das raizes foram removidos por centrifugação a 12000 g por 30 seg., coletando-se o sobrenadante. O material foi imediatamente utilizado ou então armazenado a $-20^{\circ} \mathrm{C}$. Para a PCR foram feitas séries de diluições em água com concentrações de 1:10 a 1:10.000 (vol:vol). 
5.4.3 PCR de DNA de esporos e raizes

A reação da PCR consistiu de $5 \mu 1$ do extrato cru contendo DNA de esporos ou raízes, adicionados ao mix para um volume final de $50 \mu \mathrm{l}$. A concentração final na reação foi $125 \mu \mathrm{M}$ de cada dNTP, 20 pmol de cada primer, 7,5 mM de $\mathrm{MgCl}_{2}, 1,5$ unidades de Taq polymerase Goldstar (Eurogentec, Seraing, Bélgica), sendo o tampão fornecido com a enzima e usado nas concentrações conforme indicações do fabricante. Os primers ITS 4 (5'-TCCTCCGCTTATTGATATGC- $\left.3^{\circ}\right)$ e ITS 5 (5*GGAAGTAAAAGTCGTAACAAGG-3`) (MWG-Biotech, Ebersberg, Alemanha) foram utilizados combinados.

O DNA ribossomal da região ITS foi amplificado usando um termociclador Perkin-Elmer System 2400 programado para $95^{\circ} \mathrm{C}$ por 3 minutos para desnaturação inicial, 40 ciclos de 1 minuto a $94^{\circ} \mathrm{C}$ para desnaturação, 40 segundos a $50^{\circ} \mathrm{C}$ para anelamento. 1 minuto a $72^{\circ} \mathrm{C}$ para extensão e 5 minutos a $72^{\circ} \mathrm{C}$ para extensão final. Em todos os experimentos foram usados tratamentos controle onde nenhum DNA foi colocado. Todos os tubos e materiais utilizados na composição das soluções e no manuseio foram esterilizados.

Os produtos obtidos foram separados por eletroforese em gel de agarose 1,4\%.

Os fragmentos de DNA resultantes foram visualizados através de coloração com brometo de etídeo e fotografados sob luz U.V.

Os dados de produção de esporos foram tabulados e analisados segundo sua distribuição de frequência

\subsection{Resultados}

A ocorrência de fungos MA, a esporulação no solo e a frequuência de ocorrência de fungos MA na rizosfera do cafeeiro e de Crotalaria breviflora são apresentados na Tabela 1. 
Tabela 1. Ocorrência, esporulação no solo $(E)$ e frequência de ocorrência $(F)$ de fungos micorrizicos arbusculares em solo cultivado com Cafeeiro (Coffea arabica L.) e com Crotalaria breviflora na entrelinha para adubação verde. Média de 3 repetições.

\begin{tabular}{lcccccc}
\hline \multicolumn{1}{c}{ Fungos } & \multicolumn{2}{c}{ Cafeeiro } & \multicolumn{2}{c}{ Crotalaria } & \multicolumn{2}{c}{ Controle } \\
\multicolumn{1}{c}{ micoviflora } \\
mcutellospora gilmorei & $\mathrm{E}^{1}$ & $\mathrm{~F}^{2}, \%$ & $\mathrm{E}$ & $\mathrm{F}, \%$ & $\mathrm{E}$ & $\mathrm{F}, \%$ \\
Sheterogama & 26 & 20 & 48 & 45 & 3 & 4 \\
Gigaspora margarita & - & - & - & - & 3 & 4 \\
Gi.decipiens & - & - & 9 & 9 & - & - \\
Acaulospora scrobiculata & - & - & 29 & 27 & - & - \\
A appendicula & - & 20 & 9 & 9 & 3 & 4 \\
A.longula & -6 & -38 & 11 & 10 & 7 & 11 \\
A.spinosa & - & - & - & - & 13 & 20 \\
Acaulospora sp & 6 & 5 & - & - & - & - \\
Glomus diaphanum & 28 & 22 & - & - & 19 & 31 \\
Total & 128 & 100 & 106 & 100 & 62 & 100
\end{tabular}

$1=$ número de esporos $.50 \mathrm{~g} \operatorname{solos}^{-1} ; 2=$ Porcentagem de ocorrência sobre o total de esporos observados no tratamento.

Foram observadas 10 espécies de fungos MA na área, que são: Scutellospora gilmorei, S.heterogama. Gigaspora margarita. Gi.decipiens. Acaulospora scrobiculata. A.longula, A.spinosa, A.appendicula, Acaulospora sp. e Glomus diaphanum. Entretanto, apenas 5 das 10 espécies foram observadas no cafeeiro e 5 na Crotalária. No cafeeiro ocorreram S.gilmorei, A.scrobiculata, A.longula, Acaulospora sp. e G.diaphanum, com maior ocorrência de esporos dos gêneros Acaulospora (60\% sobre o total). Na crotalária ocorreram S.gilmorei, Gi.margarita, Gi decipiens, A.scrobiculata e A.appendicula, com maior frequência de ocorrência de esporos dos gêneros Scutellospora e Gigaspora, que somados representaram $81 \%$ sobre o total (Tabela 1). No cafeeiro sem adubo verde foram observadas 7 espécies: S.gilmorei. A.scrobiculata, A.longula. A.appendícula. 
A.spinosa e G.diaphanum, sendo a mais freqüente, Acaulospora com $61 \%$ de frequência de ocorrência.

A.longula, Acaulospora sp. e Glomus sp foram observados somente em cafeeiro, sendo A.longula com freqüência de ocorrência superior a de todos os outros componentes das populações (36\%). Gi.margarita, Gi.decipiens e A.appendicula foram observados apenas na Crotalária. Entretanto, nesta, o fungo MA de maior ocorrência foi S.gilmorei (45\%), que também foi observado no cafeeiro com $19 \%$ de freqüência de ocorrência (Tabela 1). A esporulação dos fungos MA, na rizosfera do cafeeiro com adubo verde e na rizosfera da Crotalária, foi maior que no controle.

Os produtos da PCR de DNA genômico de A.longula. espécie que mostrou ocorrência específica no cafeeiro, e S.gilmorei, de ocorrência comum mas com frequência de ocorrência maior na Crotalária, são apresentados na Figura 1.

Observaram-se fragmentos de DNA de peso molecular diferente para as duas espécies de fungo MA estudadas. A.longula apresentou fragmentos amplificados de aproximadamente 580 bases pares (bp) e S.gilmorei de aproximadamente $540 \mathrm{bp}$. As amplificações obtidas de esporos diferentes, mas da mesma espécie, apresentaram bandas com o mesmo peso molecular, mas de intensidades diferentes.

Testes de diluição com extratos crus obtidos de raízes de cafeeiro colonizadas e não colonizadas por fungos MA mostraram que, para o extrato obtido e nas condições do experimento, a melhor diluição para se obter produtos de amplificação de PCR usando primers ITS 4 e 5 foi a diluição 1:100 (Figura 2). Entretanto, a freqüência de amplificações positivas foi baixa (dados não apresentados). Extratos não diluído ou diluído de 1:1000 não apresentaram amplificações. Em todas as PCR realizadas não se observaram amplificações em extratos de raízes não colonizadas e na testemunha (sem DNA). 


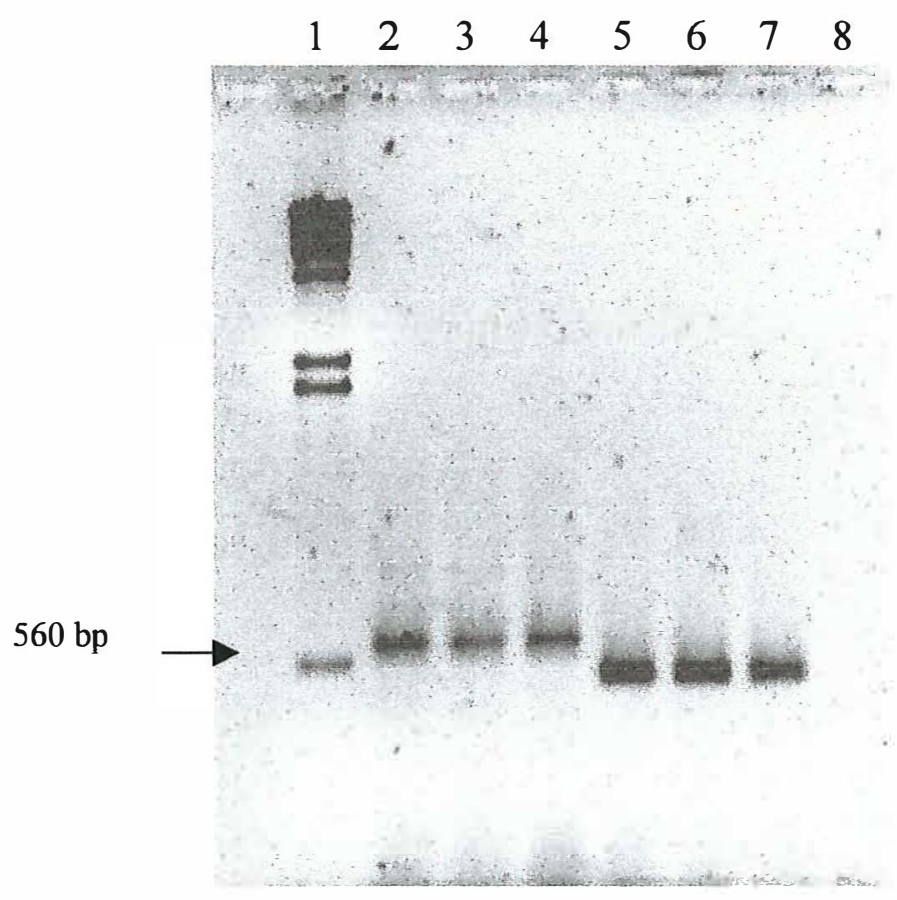

Figura 1. Produtos de amplificação de PCR com "primers" ITS 4 e 5 combinados, usando 3 extratos crus obtidos de esporo único de fungos micorrízicos arburculares. Linha 1, marcador molecular $\lambda$ digerido com HindIII; Linhas 2 a 4, Acaulospora longula; linhas 5 a 7, Scutellospora gilmorei. e linha 8, Controle.

Produtos da amplificação de fragmentos de DNA de esporos de A.longula e de raízes de cafeeiros colonizadas, usando primers de ITS 4 e 5 combinados, mostraram padrão de bandeamento semelhante e este padrão foi completamente diferente do observado para esporos de S.gilmorei (Figura 3). Fragmentos de DNA amplificados de A.longula e de raízes colonizadas apresentaram aproximadamente 580 bp. S.gilmorei apresentou segmentos amplificados de aproximadamente $540 \mathrm{bp}$, portanto diferente das raízes colonizadas. Para estas raízes observou-se também uma segunda banda, de peso 
molecular ligeiramente superior ao observado para A.longula. Raízes não colonizadas e a testemunha sem DNA não apresentaram amplificação.

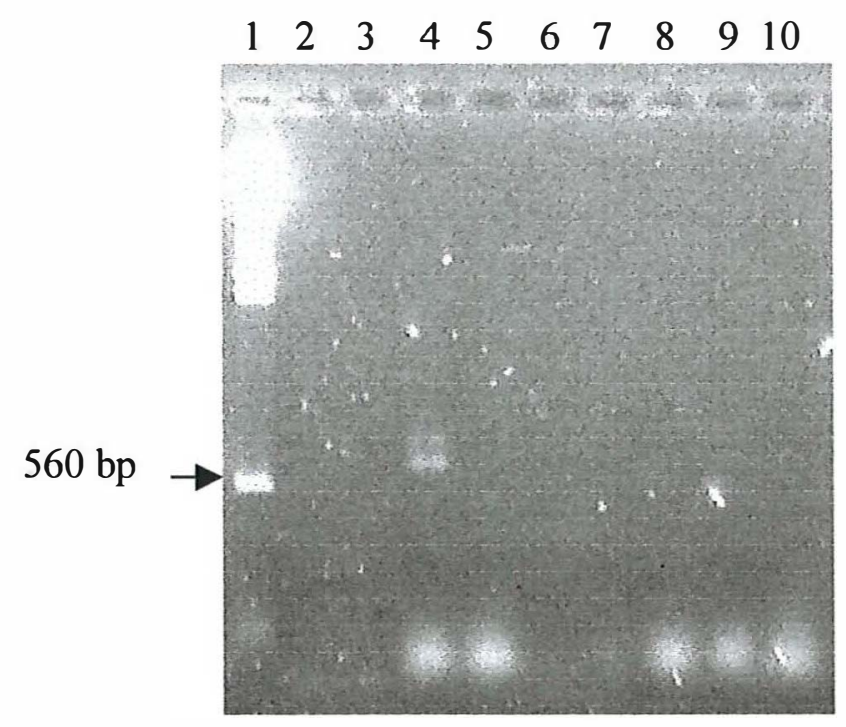

Figura 2. Produto da amplificação de PCR usando os primers ITS 4 e 5 combinados, obtidos de extrato cru de raízes de cafeeiro colonizadas ou não, em diferentes diluições (vol.:vol.). Linha 1, marcador molecular $\lambda$ digerido com HindIII; Linha 2, Raízes colonizadas (C) sem diluição; Linha 3, C 1:10; linha 4, C 1:100; linha 5, C 1:1000; linha 6, Não colonizada (NC) sem diluição; linha 7, NC 1:10; linha 8, NC 1:100; linha 9, NC 1:1000; linha 10, Controle (sem DNA e sem diluição). 




Figura 3. Produto de amplificação de PCRs obtidos de extrato cru de esporo único de fungos micorrízicos arbusculares e de raízes de cafeeiro colonizadas ou não, usando os primers ITS 4 e 5 combinados. Linha 1 , marcador molecular $\lambda$ digerido com HindIII; Linhas 2 e 3, Acaulospora longula; Linhas 4 e 5, Scutellospora gilmorei; Linhas 6 e 7, extrato de raízes colonizadas (dil. 1:100); Linhas 8 e 9, extrato de raízes não colonizadas (dil. 1:100); Linha 10, Controle (sem DNA e sem diluição). 


\subsection{Discussão}

O cultivo de leguminosas altamente micorrízicas pode aumentar o potencial de inóculo de fungos MA no solo tanto da região do cultivo como também de áreas vizinhas, e isto pode ser particularmente importante em situações de monocultivos permanentes, como é o caso do cultivo do café e de citros. Potencial de inóculo natural do solo é o conjunto de estruturas fúngicas (esporos, células auxiliares vesículas e fragmentos de hifas) presentes no solo, livres ou associadas à matéria orgânica ou agregados, capazes de infectar plantas, promover colonização radicular e estabelecer micorrizas. Monoculturas prolongadas diminuem o potencial de inóculo natural do solo e a diversidade de espécies de FMA. Segundo Johnson et al. (1992), monoculturas contínuas têm efeito negativo sobre o potencial de inóculo de fungos MA porque geralmente selecionam espécies mais adaptadas ao agrossistema, mas de eficiência simbiótica menor. Smith (1980) observou redução no potencial de inóculo de fungos MA após cultivo permanente com trigo. Entretanto, este efeito se reverteu gradualmente após três rotações na área com pastagens.

Baltruschat \& Dehne (1988) relatam efeito semelhante sobre o potencial de inóculo de FMA em solos cultivados continuamente com trigo. Neste trabalho os autores relatam também que o uso de adubação verde com plantas não micorrízicas (Brassica napus e Raphanus sativus) teve efeito negativo ainda maior sobre o potencial de inóculo de FMA. Nossos resultados mostram que o cultivo de leguminosas altamente micorrízicas na entrelinha de plantio do cafeeiro aumentou a concentração de esporos de fungos MA, tanto na entrelinha quanto na linha de plantio do cafeeiro. É possível que este aumento na concentração de esporos ocasione também aumento no potencial de inóculo natural do solo. Entretanto, isto não foi avaliado neste experimento.

Além de características de solo, a compatibilidade entre os simbiontes precisa ser considerada como um fator decisivo para a micorrização e a permanência do fungo no agrossistema. Segundo Abbott \& Robson (1991), a abundância de fungos micorrízicos nos ecossistemas naturais está relacionada à abundância de espécies de plantas, bem como ao nível de infecção das raízes destas plantas. Gomes-da-Costa (1993) estudando 
soja e milho cultivados em monoculturas ou rotação, observou mudanças quantitativas e qualitativas na comunidade de FMA relacionadas às plantas hospedeiras. Scutellospora coralloides, S.calospora e S.heterogama foram observadas apenas na rizosfera de milho em monocultura, sendo eliminadas do solo quando a soja foi cultivada em rotação (Gomes-da-Costa, 1993). Gigaspora ramisporophora, foi favorecida pela soja cultivada em monocultura. A.longula não apresentou especificidade de hospedeiro, não sendo afetada pelo manejo. Neste trabalho em discussão, observou-se a ocorrência de Gi.margarita e Gi.decipiens apenas na Crotalária e A.longula com alta freqüência (36\%) apenas no cafeeiro. Entretanto, S.gilmorei foi observada com alta freqüência em Crotalária (45\%) e também no cafeeiro (19\%), cultivado adjacente (Tabela 1).

Através da análise de fragmentos de restrição de ITS amplificados pela PCR foi possivel detectar que S.gilmorei, embora presente na rizosfera do cafeeiro, não estava de fato colonizando suas raízes.

A análise de fragmentos de restrição de ITS tem sido citada como uma valorosa ferramenta para caracterização de fungos (Gardes et al., 1991; Henrion et al., 1994; Lee \& Taylor, 1992; Zambino \& Szabo, 1993) e também de Glomales, a nível de gênero ou espécie (Redecker et al., 1997). Para Glomales, entretanto, as seqüências de ITS tem se mostrado em alguns casos heterogêneas, como por exemplo em esporos de Glomus mosseae (Lloyd-MacGilp, 1996; Sanders et al., 1995) e Gigaspora sp. (Redecker et al., 1997). Por isso, tem sido também sugerido o uso de primers de ITS específicos (Abbas et al., 1996). Entretanto, como S.gilmorei foi a única scutellospora observada no cafeeiro, as diferenças no padrão de bandas observadas foram suficientes para se poder concluir que S.gilmorei não estava colonizando as raízes do cafeeiro, sem a necessidade de análises complementares usando primers específicos.

No estudo de raízes, testes das amostras de extrato de raízes de cafeeiro colonizadas ou não indicaram a necessidade de diluições e do uso da resina Chelex. Diluições são procedimentos freqüentemente utilizados em PCR para tentar otimizar a relação primer:concentração de DNA para que os sítios de anelamento se adequem à concentração de primers utilizada. Diluições de amostras também são eficientes em eliminar inibições da PCR por substâncias fenólicas, polissacarídeos ou ácidos húmicos, 
que têm sido freqüentemente encontrados em associação com DNA de tecidos de plantas e associados com inibições da PCR (Bentivenga \& Morton, 1994; Egger \& Sigler, 1993). Chelex é uma resina catiônica capaz de eliminar contaminates de solo capazes de inibirem a PCR. O uso do Chelex, associado às diluições, foi suficiente para eliminar essas inibições.

Somente A.longula foi detectada em amostras de raízes de cafeeiro contendo $68 \%$ de colonização. A.longula e S.gilmorei nunca foram detectadas em segmentos de raízes não colonizadas e no controle. Produtos não específicos, entretanto, foram amplificados nas amostras de raízes colonizadas. A presença destes produtos de DNA em raizes colonizadas indicam a presença de outra espécie de fungo MA colonizando as raízes ou então que os primers não foram taxon-específicos e puderam amplificar DNA não micorrízico. Entretanto, essa observações não foram estudadas.

Com a técnica utilizada foi possível detectar que as raízes de cafeeiro não estavam colonizadas por S.gilmorei mas por A.longula. A colonização de raízes do cafeeiro por A.longula era esperada devido à alta freqüência de ocorrência de esporos deste fungo observada na sua rizosfera. Entretanto, a ausência de bandas de S.gilmorei nas raízes do cafeeiro surpreendentemente sugere que este fungo, apesar de ocorrer na rizosfera, não se estabeleceu efetivamente nas raízes do cafeeiro. Uma possível explicação para este fato é que S.gilmorei pode ter sido introduzido na rizosfera do cafeeiro através das raízes de Crotalária, que se estenderam até o cafeeiro, em busca de maior disponibilidade de $\mathrm{P}$.

As evidências de que fungos MA multiplicados em Crotalaria breviflora estão presentes na rizosfera do cafeeiro, mas não estão efetivamente colonizando suas raízes, sugerem a importância de se conhecer as populações de MA que determinadas espécies de plantas podem estimular, quando se pensa em rotações de culturas, pré cultivos ou cultivo intercalar como prática de manejo para aumentar o potencial de inóculo natural destes fungos no solo.

É possível que o uso de seqüências de ITS amplificadas de extratos de raizes colonizadas usando PCR e primers específicos para fungos MA, possibilite a caracterização das populações ativas destes fungos no campo, a nível de espécies. 
permitindo uma melhor compreensão das relações fungo-planta-solo e sistemas de produção.

\subsection{Conclusões}

- Cafeeiro (Coffea arabica L.) e Crotalaria breviflora estimularam populações diferentes de fungos micorrízicos arbusculares na sua rizosfera.

- Acaulospora longula e Scutellospora gilmorei produziram fragmentos de DNA de pesos moleculares diferentes ( 580 e 540 pares de bases, respectivamente).

- Usando primers da região ITS 4 e 5 combinados e amplificando fragmentos obtidos através da PCR foi possível identificar fungos micorrízicos colonizando as raízes do cafeeiro.

- Através de técnicas moleculares foi possível detectar que o fungo micorrízico Scutellospora gilmorei, de ocorrência comum em rizosfera de cafeeiro (Coffea arabica L.) e Crotalaria breviflora, não colonizou as raízes do cafeeiro.

- O uso de técnicas moleculares tem potencial para auxiliar no estudo da dinâmica dos fungos micorrízicos arbusculares no sistema solo-planta. 


\section{CONCLUSÕES}

Os resultados obtidos permitem as seguintes conclusões:

- O cultivo de leguminosas aumentou a diversidade de fungos micorrízicos arbusculares e a concentração de esporos de fungos micorrízicos arbusculares no solo.

- O cultivo de leguminosas para adubação verde na entrelinha do cafeeiro aumentou a diversidade de espécies e o número de esporos de fungos micorrízicos arbusculares na rizosfera do cafeeiro.

- O cafeeiro e as leguminosas estimularam populações de fungos micorrízicos diferentes na sua rizosfera. Acaulosporaceae são mais freqüentes no cafeeiro e Gigasporeceae, principalmente Scutellospora gilmorei, nas leguminosas.

- Em bioensaios em casa de vegetação, Gigasporaceae não foram encontradas colonizando as raízes do cafeeiro.

- A adubação verde pode não ser eficiente em aumentar o efeito biofertilizante da micorrização, devido à ocorrência de relações preferencias entre fungo e hospedeiro.

- A metodologia desenvolvida para extração de DNA de fungos micorrízicos arbusculares permite a extração de DNA de um único esporo, de forma rápida e de maneira simplificada.

- O DNA de fungos micorrízicos arbusculares obtido através da metodologia de extração desenvolvida neste trabalho é de qualidade e em quantidade suficiente para amplificação e sequenciamento.

- A eficiência da amplificação de fragmentos de DNA através da PCR varia em função da espécie de fungo micorrízico arbuscular.

- Acaulospora longula e Scutellospora gilmorei produziram fragmentos de DNA de pesos moleculares diferentes ( 580 e 540 pares de bases, respectivamente).

- Usando primers da região ITS 4 e 5 combinados e amplificando fragmentos obtidos através da PCR foi possível identificar fungos micorrizicos colonizando as raízes do cafeeiro. 
- Através de técnicas moleculares constatou-se que o fungo micorrízico Scutellospora gilmorei, de ocorrência comum em Cafeeiro (Coffea arabica L.) e Crotalaria breviflora, não estava colonizando as raízes do cafeeiro.

- O uso de técnicas moleculares pode auxiliar no estudo da dinâmica dos fungos micorrízicos arbusculares no solo e na planta. 


\section{REFERÊNCIAS BIBLIOGRÁFICAS}

ABBAS, D.J.; HETRICK, B.A.D.; JURGENSON, J.E. Isolate specific detection of mycorrhizal fungi using genome specific primer pairs. Mycologia, v.88, n.6, p.939946, 1996.

ABBOTT, L.K.; GAZEY, C. An ecological view of the formation of VA mycorrhizas. Plant and Soil, v.159, p.69-78, 1994.

ABBOTT, L.K.; ROBSON, A.D.;Infectivity of vesicular-arbuscular mycorrhizal fungi in agricultural soils. Australian Journal of Agricultural Research, v.33, p.10491059, 1982

ABBOTT, L.K.; ROBSON, A.D.; The effect of VA mycorrhizae on plant growth. In: POWELL, C.L.; BAGYARAJ, D.J. (Ed.) V. A. Mycorrhiza. Boca Raton: CRC Press, 1984. p. 113-130.

ABBOTT, L.K.; ROBSON, A.D. Formation of external hyphae in soil by four species of vesicular-arbuscular mycorrhizal fungi. New Phytologist, v.99, p.245-255, 1985.

ABBOTT, L.K.; ROBSON, A.D.; Factors influencing the occurrence of vesiculararbuscular mycorrhizas. Agriculture, Ecosystems and Environmemt, v.35, p.121150, 1991.

ABBOTT, L.K.; ROBSON, A.D.; DE BOER, G. The effect of phosphorus on the formation of hyphae in soil by the vesicular-arbuscular mycorrhizal fungus, Glomus fasciculatum. New Phytologist. v.97, p.437-446. 1984. 
ALLEN, M.F. Mycorrhizal functioning: an integrative plant-fungal process. New York: Chapman \& Hall, 1992. 515p.

ANTUNES, V.; SILVEIRA, A.P.; CARDOSO, E.J.B.N. Interação entre diferentes tipos de solo e fungos micorrízicos vesículo-arbusculares na produção de mudas de café. Turrialba, v.38, n.2, p.117-122, 1988.

BALOTA, E.L. Flutuação sazonal de fungos micorrízicos vesículo-arbusculares no cafeeiro (Coffea arabica L.). Piracicaba. 1989. 145p. Dissertação (M.S.) - Escola Superior de Agricultura Luiz de Queiroz.

BALOTA, E.L.; LOPES, E.S. Introdução de fungo micorrízico arbuscular no cafeeiro em condições de campo: I. Persistência e interação com espécies nativas. Revista Brasileira de Ciência do Solo, v.20, p.217-223, 1996a.

BALOTA, E.L.; LOPES, E.S. Introdução de fungo micorrízico arbuscular no cafeeiro em condições de campo: II. Flutuação sazonal de raízes, de colonização e de fungos micorrízicos arbusculares associados. Revista Brasileira de Ciência do Solo, v.20, p.225-232, 1996b.

BALTRUSCHAT, H.; DEHNE, H.W. The occurrence of vesicular-arbuscular mycorrhiza in agro-ecosystems. I. Influence of nitrogen fertilization and green manure in continuous monoculture and in crop rotation on the inoculum potential of winter wheat. Plant and Soil, v.107, p.279-284. 1988 
BALTRUSCHAT, H.; DEHNE, H.W. The occurrence of vesicular-arbuscular mycorrhizal fungi in agro-ecosystems. II. Influence of nitrogen fertilization and green manure in continuous monoculture and in crop rotation on the inoculum potential of winter barley. Plant and Soil, v.113, p.251-256, 1989.

BAREA, J.M.; AZCÓN-AGUILAR,C. Mycorrhizas and their significances in in nodulation nitrogen fixing plants. Advances in Agronomy, n.36, p.1-54, 1983.

BENTIVENGA, S.P. ; MORTON, J.B. Stability and heritability of fatty acid methyl ester profiles of glomalean endomycorrhizal fungi. Mycological Research, v.98, p.1419-1426, 1994.

BETHLENFALVAY, G.J. Mycorrhizae and crop productivity. In: BETHLENFALVAY, G.J.; LINDERMAN, R.G. (Ed.) Mycorhizae in Sustainable Agricu ltu re, Madson: American Society of Agronomy, 1992. p.1-25.

BETHLENFALVAY, G.J.; BAYNE, H.C.; PACOVSKY, R.S. Parasitic and mutualistic association between a mycorrhizal fungus and soybean. Physiologia Plantarum. v.57, p.543-549. 1983.

BETHLENFALVAY, G.J.; BROWN, M.S.; FRANSOS, R.L.; MIHARA, K.L. The Glycine-Glomus-Bradyrhizobium symbiosis: IX. Nutritional, morphological and physiological responses of nodulated soybean to geographic isolates of the mycorrhizal fungus Glomus mosseae. Physiologia Plantarum, v.76, p.226-232. 1989.

BETHLENFALVAY, G.J.; LINDREMAN, R.G. Mycorrhizae in sustainable agriculture, Madson: American Society of Agronomy, 1992. 135p. 
BLACK, R.; TINKER, P.B. The development of endomycorrhizal root systems: II. Effect of agronomic factors and soil conditions on the development of vesiculararbuscular mycorrhizal infection in barley and on the endophyte spore density. New Phytologist, v.83, p.401-413, 1979.

BONITO, R.D.; ELLIOT, M.L.; DES JARDINS, E.A. Detection of an arbuscular mycorrhizal fungus in roots of different plant species with the PCR. Applied and Environmental Microbiology, v.61, p.2809-2810, 1995.

BRAUN-BLANQUET, J. Tabulacion de las comunidades. In: BRAUN-BLANQUET, J. (Ed.) Fitosociologia - bases para el estudio de las comunidades vegetales. Madrid: H.Blume ediciones, 1979. p.65-96.

BRUNS, T.D.; GARDES, M. Molecular tools for the identification of ectomycorrhizal fungi taxon-specific oligonucleotide probes for suilloid fungi. Molecular Ecology, v.2, p.233-242, 1993.

BRUNS, T.D.; WHITE, T.J.; TAYLOR, J.W. Fungal molecular systematics. Annual Review of Ecology System, v.22, p.525-564, 1991.

CARDOSO, E.J.B.N. Ocorrência de micorrizas em café. Summa Phytopathologica, v.4, p.136-137, 1978.

CARDOSO, E.J.B.N. Efeito de micorriza vesículo-arbuscular e fosfato de rocha na simbiose soja-Rhizobium. Revista Brasileira de Ciência do Solo. v.9, p.125-130, 1985. 
CLAPP, J.P.; YOUNG, J.P.W.; MERRYWEATHER, J.W.; FITTER, A.H. Diversity of fungal symbionts in arbuscular mycorrhizas from a natural community. New Phytologist, v.130, p.259-266, 1995.

COLOZZI FILHO, A.; BALOTA, E.L. Potencial de inóculo de fungos micorrízicos arbusculares em solo cultivado com cafeeiro e leguminosas de verão. In: REUNIÃO BRASILEIRA SOBRE MICORRIZAS, V, Florianópolis, 1994. Resumos. Florianópolis: Universidade Federal de Santa Catarina, 1994. p-17.

COLOZZI FILHO, A.; SIQUEIRA, J.O. Micorrizas vesículo-arbusculares em mudas de cafeeiro. I. Efeitos de Gigaspora margarita e adubação fosfatada no crescimento e nutrição. Revista Brasileira de Ciência do Solo, v.10, p.199-205, 1986.

COLOZZI FILHO, A.; SIQUEIRA, J.O.; SAGGIN-JÚNIOR, O.J.; GUIMARÃES, P.T.G.; OLIVEIRA, E. Efetividade de diferentes fungos micorrízicos arbusculares na formação de mudas, crescimento pós-transplante e produção do cafeeiro. Pesquisa Agropecuária Brasileira, v.29, n.9, p.1397-1406, 1994.

COLOZZI FILHO, A.; SOUZA, P.; OLIVEIRA, E.; CARVALHO, M.M. Desenvolvimento de mudas de cafeeiro "Catuaí" micorrizadas. Fitopatologia Brasileira, v.10, p.335, 1985.

COOPERBAND, L.R.; BOERNER, R.E.J.; LOGAN, T.J., Humid tropical leguminous tree and pasture grass responsiveness to vesicular-arbuscular mycorrhizal infection. Mycorrhiza. v.4, p.233-239, 1994. 
CUENCA, G.; LOVERA, M. Vesicular-arbuscular mycorrhizae en disturb and revegetated sites from La Gran Sabana, Venezuela. Canadian Journal of Botany, v.70, p.73-79, 1992.

DODD, J.C.; ARIAS, I., KOOMEN, I.; HAYMAN, D.S. The management of populations of vesicular-arbuscular mycorrizal fungi in acid-infertile soils sf a savanna ecosystem. I: The effects of pre-cropping and inoculation with VAM-fungi on plant growth and nutrition in the field. Plant and Soil, v.122, p.229-240, 1990a.

DODD, J.C.; ARIAS, I.; KOOMEN, I.; HAYMAN, D.S. The management of populations of vesicular-arbuscular mycorrhizal fungi in acid-infertile soils of a savanna ecosystem. II. The effects of pre-cropping on the spore populations of native and introduced VAM fungi. Plant and Soil, v.122, p.241-247, $1990 \mathrm{~b}$.

DOUDS, D.D.; SCHENCK, N.C. Relationship of colonization and sporulation by va mycorrhizal fungi to plant nutrient and carbohydrate contents. New Phytologist, v.116, p.621-627, 1990.

EDWARDS, S.G.; FITTER, A.H.; YOUNG, J.P.W. Quantification of an arbuscular mycorrhizal fungus, Glomus mosseae, within plant roots by competitive polymerase chain reaction. Mycological Research. v.101, n.12. p.1440-1444, 1997.

EGGER, K.N.; FORTIN, J.A. Identification of taxa of E-strain mycorrhizal fungi by restriction fragment analysis. Canadian Journal of Botany, v.68, p.1482-1488, 1990. 
EGGER, K.N.; SIGLER, L. Relatedness of the ericoid endophytes Scytalidium vacinii and Hymenoscyphus ericae inferred from analysis of ribosomal DNA. Mycologia, v.85, p.219-230, 1993.

ESPINDOLA, J.A.A.; ALMEIDA, D.L.; GUERRA, J.G.M.; SILVA, E.M.R. \& SOUZA, F.A. Influência da adubação verde sobre a simbiose micorrízica e a produção da batata-doce (Ipomea batatas (L.) Lam.). In: REUNIÃO BRASILEIRA SOBRE MICORRIZAS, V, Florianópolis, 1994. Resumos, Florianópolis: Universidade Federal de Santa Catarina, 1994. p.46

FERNANDES, A.B. Micorrizas vesículo-arbusculares em cafeeiro da região sul do Estado de Minas Gerais. Lavras, 1987. 98p. Dissertação (M.S.) - Escola Superior de Agricultura de Lavras.

FERNANDES, A.B. \& SIQUEIRA, J.O. Micorrizas vesicular-arbusculares em cafeeiros da região sul do Estado de Minas Gerais. Pesquisa Agropecuária Brasileira, v.24, n.12, p.1489-1498, 1989.

FRANKIE, M.; MORTON, J. Ontogenetic comparisons of arbuscular mycorrhizal fungi Scutellospora heterogama and Scutellospora pellucida: revision of taxonomic character concepts, species descriptions, and phylogenetic hypothesis. Canadian Journal of Botany, v.71. p.122-134, 1994.

GARDES, M.; BRUNS, T.D. ITS primers with enhanced specificity for basidiomycetes application to the identification of mycorrhizae and rusts. Molecular Ecology, v.2, p.113-118, 1993. 
GARDES, M.; WHITE, T.J.; FORTIN, J.A.; BRUNS, T.D.; TAYLOR, J.W. Identification of indigenous and introduced symbiotic fungi in ectomycorrhyzae by amplification of nuclear and mitocondrial DNA. Canadian Journal of Botany, v.69, p.180-190, 1991.

GERDEMANN, J.W. Vesicular-arbuscular mycorrhizae. In: TORREEY, J.G.; CLARKSON, D.T. (Ed.) The Development and Function of Roots. Londres:Academic Press, 1975. p.575-591.

GERDEMANN, J.W.; NICOLSON, T.H. Spores of mycorrhizal Endogone species extracted from soil by wet sieving and decanting. Transaction of the British Mycological Society, v.46, p.235-244, 1963.

GIOVANNETI, M.; MOSSE, B. An evaluation of techiniques for measuring vesicular arbuscular mycorrhizal infecion in roots. New Phytologist, v.84, p.489-500, 1980.

GIOVANNETTI, M.; SBRANA, C.; AVIO, L.; CITERNESI, A.S.; LOGI, C. Diferential hyphal morphogenesis in arbuscular mycorrhizal fungi during preinfection stages. New Phytologist, v.125, p.587-594, 1993.

GIOVANNETTI, M.; SBRANA, C.; CITERNESI, A.S.; AVIO, L. Analysis of factors involved in fungal recognition responses to host-derived signals by arbuscular mycorrhizal fungi. New Phytologist, v.133, p.65-71, 1996.

GIOVANNETTI, M.; SBRANA, C.; LOGI, C. Early processes involved in host recognition by arbuscular mycorrhizal fungi. New Phytologist, v.127, p.703-79. 1994. 
GOMES-DA-COSTA, S.M. Fungos micorrízicos arbusculares em monoculturas e rotações de milho (Zea mays L.) e soja (Glycine max (L.) Merrill. Rio Claro, SP, 1993, 112p Tese (Doutorado) - Universidade Estadual Paulista.

GOMES-DA-COSTA, S.M.; OLIVEIRA, A.A.F. Crescimento de soja em solos com diferentes potenciais de inóculo de fungos micorrízicos arbusculares autóctones. In: CONGRESSO NACIONAL DE BOTÂNICA, XLVII, Nova Friburgo, 1996. Resumos, Nova Friburgo, Sociedade de Botanica do Brasil, 1996. p.312.

GRAHAM, J.H.; EISSENSTAT, D.M. Host genotype and the formation and function of VA mycorrhizae. Plant and Soil, v.159, p.179-185, 1994.

GRAHAM, J.H.; LINDERMAN, R.G.; MENGE, J.A. Development of external hyphae by different isolates of mycorrhizal Glomus spp. in relation to root colonization and growth of troyer citrange. New Phytologist, v.91, p.183-189, 1982.

GRAVES, J.D.; WATKINS, N.K,; FITTER,A.H.; ROBINSON, D.; SCRIMGEOUR,C. Intraspecific transfer of carbon between plants linked by a common mycorrhizal network. Plant and Soil, v.192, p.153-159, 1997.

HALL, I.R. Potential for exploiting vesicular-arbuscularmycorrhizas in agriculture. In: MIZARAHI, A. (Ed.) Advances in Biotechnological Processes. New York: Alan Liss Inc., 1988. p.141-174.

HARINIKUMAR, K.M.; BAGYARAJ, D.J. Effect of crop rotation on native vesiculararbuscular mycorrhizal propagules in soil. Plant and Soil, v.110, p.77-80, 1988. 
HARNEY, S.K.; EDWARDS, F.S.; ALLEN, M.F. Identification of arbuscular mycorrhizal fungi from Artemisia californica using the polymerase chain reaction. Mycologia, v.89, n.4, p.547-550, 1997.

HENRION, B.; CHEVALIER,G.; MARTIN, F. Typing truffle species by PCR amplification of the ribosomal DNA spacers. Mycological Research, v.98, p.37-43, 1994.

HENRION, B.; LE TACON, F.; MARTIN, F. Rapid identification of genetic variation of ectomycorrhizal fungi by amplification of ribossomal RNA genes. New Phytologist, v.122, p.289-298, 1992.

HEPPER, C.M.; SEN, R.; AZCON-AGUILAR, C.; GRACE, C. Variation in certain isozymes among different geographical isolates of the vesicular-arbuscular mycorrhizal fungi Glomus monosporum and Glomus mossae. Soil Biology and Biochemistry, v.20, p.51-59, 1988.

HERRERA, M.A.; SALAMANCA, C.P.; BAREA, J.M. Inoculation of woody legumes with selected arbuscular mycorrhizal fungi and rhizobia to recover desertified mediterranean ecosystems. Applied and Environmental Microbiology, v.48, n.1, p.206-210, 1984.

HETRICK, B.A.D.; WILSON, G.W.T. Effects of mycorrhizal fungus species and metalaxyl application on microbial suppression of mycorrhizal symbiosis. Mycologia. v.83, p.97-102. 1991. 
HUNGRIA, M.; ANDRADE, D.S.; COLOZZI-FILHO, A.; BALOTA, E.L.; SANTOS J.C.F. Ecologia microbiana em solos sob cultivo na região sul do Brasil. In: SIMPÓSIO BRASILEIRO SOBRE MICROBIOLOGIA DO SOLO, 3.; REUNIÃO DE LABORATÓRIOS PARA RECOMENDAÇÃO DE ESTIRPES DE RHIZOBIUM E BRADYRHIZOBIUM, 6., Londrina, 1994. Anais. Londrina: IAPAR, 1994. p.234-270.

INGLEBY, K.; DIAGNE, O.; DEANS, J.D.; LINDLEY, D.K.; NEYRA, M.; DUCOUSSO, M. Distribution of roots, arbuscular mycorrhizal colonization and spores fast-growing tree species in Senegal. Forest Ecology and Manegement, v.90, p.19-27, 1997.

JANOS, D.P. Mycorrhizae influence tropical succession. Biotropica, v.12, p.56-64, 1980.

JANOS, D.P. Mycorrhizas, succession, and the rehabilitation of deforested lands in the humid tropics. In: FRANKLAND, J.C.; MAGAN, N.; GADD, G.M. (Ed.) Fungi and Environ mental Change. Cambridge: Cambridge University Press, 1995. p.129-162.

JANOS, D.P. Mycorrhizas applications in tropical forestry: are temperate-zone approaches appropriate? In: JANOS, D.P. (Ed.) Trees and mycorrhiza forest. Kuala Lumpur. Research Institute Malaysia, 1988. p.133-188.

JOHNSON, N.C.; COPELAND, P.J.; CROOKSTON, R.K.; PFLEGER, F.L. Mycorrhizae: possible explanation for yield decline with continuous corn and soybean. Agronomy Journal, v.84, p.387-390, 1992. 
JOHNSON, N.C.; PFLEGER, F.L. Vesicular-arbuscular mycorrhizae and cultural stresses. In: BETHLENFALVAY, G.J.; LINDERMAN, R.G. (Ed.) Mycorrhizae in sustainable agriculture, Madison: ASA Special Publication, 1992. p.71-99.

JOHNSON, N.C.; PFLEGER, F.L.; CROOKSTON, R.K.; SIMMONS, S.R.; COPELAND, P.J. Vesicular-arbuscular mycorrhizas respond to corn and soybeans cropping history. New Phytologist, v.117, p.657-663, 1991

KOIDE, R. Nutrient supply, nutrient demand and plant response to mycorrhizal infection. New Phytologist, v.117, p.365-386, 1991.

KOIDE, R.T.; LI, M. On host regularion of the vesicular-arbuscular mycorrhizal symbiosis. New Phytologist, v.114, p.59-74, 1990.

LANFRANCO, L.; WYSS, P.; MARZACHI, C.; BONFANTE, P. DNA probes for identification of the ectomycorrhizal fungus Tuber magnatum Pico. FEMS Microbiology Letters, v.114, p.245-252, 1993.

LANFRANCO, L.; WYSS, P.; MARZACHI, C.; BONFANTE, P. Generation of RAPDPCR primers for the identification of isolates of Glomus mosseae, an arbuscular mycorrhizal fungus. Molecular Ecology, v.4, p.61-68, 1995.

LEE, S.B.; TAYOR, J.W. Isolation of DNA from fungal mycelia and singles spores. In: INNIS, M.A.; GELFAND, D.H.; SNINSKY, J.J.; WHITE, T.J. (Ed.) PCR protocols: a guide to methods and applications. New York: Academic Press, 1990, p.282-287 
LEE, S.B.; TAYLOR, J.W. Phylogeny of five fungus-like protoctistan Phytophhora species, inferred from the internal transcribed spacers of ribosomal DNA. Molecular Biology and Evolution, v.9, p.636-653, 1992.

LLOYD-MACGILP, A.S.; CHAMBERS, S.M.; DODD, J.C.; FITTER, A.H.; WALKER, C.; YOUNG, J.P.W. Diversity of the ribosomal internal transcribed spacers within and among isolates of Glomus mosseae and related mycorrhizal fungi. New Phytologist, v.133, p.103-111, 1996.

LOPES, E.S.; OLIVEIRA, E.; DIAS, R.; SCHENCK, N.C. Occurrence and distribution of vesicular-arbuscular mycorrhizal fungi in coffe (Coffea arabica L.) plantations in central São Paulo State, Brazil. Turrialba, v.33, n.4, p.417-422, 1983a.

LOPES, E.S.; OLIVEIRA, E.; NEPTUNE, A.M.L.; MORAES, F.R.P. Efeito da inoculação do cafeeiro com diferentes espécies de fungos micorrízicos vesiculararbusculares. Revista Brasileira de Ciência do Solo, v.7, n.2. p.137-141, 1983 b.

MANJUNATH, A.; HABTE, M. Establishment of soil solution P levels for studies involving vesicular-arbuscular mycorrhizal symbiosis. Communications in Soil Science and Plant Analysis, v.21, n.7-8, p.557-566, 1990.

MARX, D.H.; BRYAN, W.C. Growth and ectomicorrhizal development of loblolly pine seedlings in fumigated soil infested with the fungal symbiont Pidoliyhud tinctorius. Forest Science, v. 21, p. 245-254. 1975.

McGONIGLE, T.P.; FITTER, A.H. Ecological specificity of vesicular-arbuscular mycorrhizal associations. Mycological Research, v.94, n.1, p.120-122, 1990. 
MICALES, J.A.; PONB, M.R.; PETERSON, G.L. The use of isozyme analysis in fungal taxonomy and genetics. Mycotaxon, v.27, p.405-409, 1986.

MICHELMORE, R. W.; HUMBERT, S.H. Molecular markers for genetic analysis of phytopathogenic fungi. Annual Review Phytopathology, v.25, p.383-404,1987.

MILLER, R.M The ecology of vesicular-arbuscular mycorrhizae in grass and shrublands. In: SAFIR, G.R. (Ed.) Ecophysiology of VA Mycorrhizal Plants. Florida: CRC Press. 1987. p.135-169.

MILLER, R.M.; JASTROW, J.D. Vesicular-arbuscular mycorrhizae and biogeochimical cycling. In: PFLEGER, F.L.; LINDERMAN, R.G. (Ed.) Mycorrhizae and Plant Health. Minnesota.: APS Press. 1994. p 189-212.

MORTON, J.B.; BENNY, G.L. Revised classification of arbuscular mycorrhizal fungi (Zygomycetes): a new order, Glomales, two new suborders, Glominae and Gigasporinae, and two new families, Acaulosporaceae and Gigasporaceae, with an emendation of Glomaceae. Mycotaxon, v.37. p.471-491, 1990.

MORTON, J.B.; BENTIVENGA, P. Levels of diversity in endomycorrhizal fungi (Glomales, Zygomicetes) and their role in defining taxonomic and non-taxonomic groups. IN: ROBSON, A.D.; ABBOT, L.K.; MALAJCZUK; N. (Ed.) Management of mycorrhizae in agriculture, horticulture and forestry. Kluwer Academic Publishers. 1994, p 47-59.

MOSSE. B. Specificity of vesicular-arbuscular mycorrhizas. In: SANDERS, F.E.; MOSSE. B.; TINKER, P.B. (Ed.) Endomycorrhizas. New York: Academic Press, 1975. p.469-484. 
NEWMAN, E.I. Mycorrhizal links between plants: their functioning and ecological significance. Advanced Ecologycal Research., v.18, p.243-270, 1988.

OLIVEIRA, E. Fungos endogonaceae em cafeeiros das regiões "Alto Paranaíba"e "Triângulo" em Minas Gerais. Lavras, 1988. 73p. Dissertação (M.S.)- Escola Superior de Agricultura de Lavras.

OLIVEIRA, E.; SIQUEIRA, J.O.; LIMA, R.D.; COLOZZI FILHO, A.; SOUZA, P. Ocorrência de fungos micorrízicos vesículo-arbusculares em cafeeiros da região do Alto Paranaíba e Triângulo no Estado de Minas Gerais. Hoehnea, v.17, n.2, p.117$125,1990$.

PACOVSKY, R.S. Carbohydrate, proteins and amino-acids status of Glycine-GlomusBradyrhizobium symbioses. Physiologia Plantarum, v. 75, p. 346-354, 1989.

PACOVSKY, R.S.; BETHLENFALVAY, G.J. Measurement of the extraradical mycelium of a vesicular-arbuscular mycorrhizal fungus in soil by chitin determination. Plant and Soil, v.68, p.143-147, 1982.

PAULA, M.A.; SIQUEIRA, J.O.; OLIVEIRA, L.H.; OLIVEIRA, E. Efetividade simbiótica relativa em soja de populações de fungos endomicorrízicos nativos e de isolados de Glomus macrocarpum e Gigaspora margarita. Revista Brasileira de Ciência do Solo. n.12. p.25-31. 1988.

PENG, S.; EISSENSTAT, D.M.; GRAHAM, J.H.; WILLIAMS, K. Growth depression in mycorrhizal citrus at high phosphorus supply: Analysis of carbon costs. Plant Physiology, v.101, p.1063-1071, 1993. 
PHILLIPS, J.M.; HAYMAN, D.S. Improved procedures for clearing roots and staining parasitic and vesicular-arbuscular mycorrhizal fungi for rapid assessment of infection. Transactions of the British Mycological Society, v.55, n.1, p.158-60, 1970.

PICHÉ, Y.; SIMON, L.; SÉGUIN, A genetic manipulation in vesicular-arbuscular mycorrhizal fungi. Plant and Soil, v.159, p.171-178, 1994

PORTER, W.M.; ROBSON, A.D.; ABBOTT, L.K. Field survey of the distribution of vesicular-arbuscular mycorrhizal fungi in relation to soil pH. Journal of Applied Ecology, v.24, p.659-662, 1987.

READ, D.J. Mycorrhizas in ecosystems. Experientia, v.47, p.376-390, 1991.

REDECKER, D.; THIERFELDER, H.; WALKER, C.; WERNER, D. Restriction analysis of PCR-amplified internal transcribed spacers of ribosomal DNA as a tool for species identification in different genera of the order Glomales. Applied and Environmental Microbiology, v.63, n.5, p.1756-1761, 1997.

ROSS, J.P. \& DANIELS, B.A. Hyperparasitism of endomycorrhizal fungi. In: N.C. SCHENCK, (Ed.), Methods and Principles of Mycorrhizal Research. St. Paul: The American Phytophatological Society Press. 1982. p.55-58.

ROSENDAHL, S.; SEN, R. Isozyme analysis of micorrhyzal fungi and their mycorrhiza. In: NORRIS; J.R.; READ; D.J.; VARMA; A. K. (Ed.) Methods in micobiology. New York: Academic Press, 1992. p.169-194. 
SAGGIN JUNIOR, O.J.; SIQUEIRA, J.O. Micorrizas arbusculares em cafeeiro. In: SIQUEIRA, J.O. (Ed.) Avanços em fundamentos e aplicações de micorrizas. Lavras, MG: Universidade Federal de Lavras, 1996, p.202-254.

SANDERS, I.R.; ALT, M.; GROPPE, K.; BOLLER, T.; WIEMKEN, A. Identification of ribosomal DNA polymorphisms among and within spores of the Glomales: application to studies on the genetic diversity of arbuscular mycorrhizal fungal communities. New Phytologist. v.130, p.419-427, 1995.

SANGER, F.; NICKLEN, S.; COULSON A.R. A rapid mehod for determining sequences in DNA by primed synthesis with DNA polymerase. Proceedings of the National Academic Science, v.74, p.5463-546, 1977.

SCANNERINI, S.; BONFANTE, P. Bacteria and bacteria-like objects in endomycorrhzal fungi (Glomaceae). In: MARGULIS, L.; FESTER, R. Symbioses as a Source of Evolutionary Innovation: Speciation and Morphogenesis. Cambridge: MIT Press, 1991. p.273-283.

SCHENK, N.C.; PEREZ, Y. Manual for the identification of VA mycorrhizal fungi.: Gainesville: University of Florida. 1987. 242p.

SCHENCK, N.C.; SIQUEIRA, J.O. Ecology of VA mycorrhizal fungi in temperate agroecosystems. In: NORTH AMERICAN CONFERENCE ON MYCORRHIZAE, VII. Gainesville,1987 Mycorrhizae in the next decade-pratical aplications and research priorities, Proceddings. Gainesville, 1987. p 2-4. 
SCHOWALTER, D.B.; SOMMER, S.S. The generation of radiolabeled DNA and RNA probes with polymerase chain reaction. Analytical Biochemistry, v.177, p.90-94, 1989.

SCHWAB, S.M.; LEONARD, R.T.; MENGE, J.A. Quantitative and qualitative comparison of roots exudates of mycorrhzal and nonmycorrhizal plant species. Canadian Journal of Botany, v.62, p.1227-1231, 1984.

SIEVERDING, E. Vesicular - arbuscular mycorrhyza management in tropical agrosystems. Eschborn, Germany: GTZ, 1991.371p.

SIEVERDING, E.; LIEHNER, D.E. Influence of crop rotation and intercropping of cassava with legumes on VA mycorrhizal symbiosis of cassava. Plant and Soil, v.80, p.143-146, 1984.

SILVEIRA, A.P.D. Micorrizas. In: CARDOSO, E.J.B.N; TSAI, S.M.; NEVES, M.C.P. (Ed.) Microbiologia do solo. Campinas: Sociedade Brasileira de Ciência do Solo, 1992. p.257-282.

SIMON, L.; LALONDE, M.; BRUNS, T.D. Specific amplification of 18 S fungal ribosomal genes from vesicular-arbuscular endomycorrhizal fungi colonizing roots. Applied Environmental Microbiology, v.58, p.291-295, 1992.

SIMON, L.; LEVESQUE, R.C.; LALONDE, M. Identification of endomycorrhizal fungi colonizing roots by fluorescent single strand conformating polymorphism polymerase chain reaction. Applied Environmental Microbiology, V.59, p.4211$4215,1993$. 
SIQUEIRA, J.O.; COLOZZI FILHO, A. Micorrizas vesículo-arbusculares em mudas de cafeeiro. II. Efeito do fósforo no estabelecimento e funcionamento da simbiose. Revista Brasileira de Ciência do Solo, v.10, p.207-211, 1986.

SIQUEIRA, J.O.; COLOZZI FILHO, A.; FARIA, F.H.S.; OLIVEIRA, E. Efetividade simbiótica de fungos micorrízicos vesicular-arbusculares para o algodoeiro. Revista Brasileira de Ciência do Solo, v.10, n.3, p.213-218, 1986.

SIQUEIRA, J.O.; COLOZZI FILHO, A.; GUIMARÃES, P.T.G.; OLIVEIRA. E. Crescimento de mudas e produção do cafeeiro sob influência da inoculação com fungos micorrízicos e superfosfato. Revista Brasileira de Ciência do Solo, v.17, n.1, p.3-87, 1993.

SIQUEIRA, J.O. \& FRANCO, A.A. Biotecnologia do Solo: Fundamentos e Perspectivas. Lavras: Esal/Faepe, 1988. 236p.

SIQUEIRA, J.O.; ROCHA JÚNIOR, W.F.; OLIVEIRA, E.; COLOZZI FILHO, A. The relationship between vesicular-arbuscular mycorrhiza and lime: associated effects on the growth and nutrition of brachiaria grass (Brachiaria decumbens). Biology and Fertility of Soils, v.10, p.65-71. 1990.

SIQUEIRA, J.O.; COLOZZI FILHO, A.; OLIVEIRA, E. Ocorrência de micorrizas vesicular-arbusculares em agro e ecossistemas do estado de Minas Gerais. Pesquisa Agropecuária Brasileira. v.24, n.12. p.1499-1506. 1989.

SIQUEIRA, J.O.; SAFIR, G.R.; NAIR, M.G. Stimulation of vesicular arbuscular mycorrhizal formation and growth of white clover by glavonoids compounds. New Phytologist, v.118, p.87-93, 1991. 
SIQUEIRA, J.O.; SAGGIN JUNIOR, O.J. The importance of mycorrhizae association in natural low-fertility soils. In: MACHADO, A.T.; MAGNAVACA, R.; PANDEY, S.; SILVA, A.F. (Ed.) Proceedings International Symposium on Environmental Stress: Maize in Perspective. Brasil/México: EMBRAPA/CYMMYT/UNDT, 1995. p.240-280.

SMITH, S.E.; GIANINAZZI-PEARSON, V. Physiological interactions between symbionts in vesicular-arbuscular mycorrhizal plants. Annual Review on Plant Physiology and Plant Molecular Biology, v.39, p.221-244, 1988.

SMITH, S.E.; GIANINAZZI-PEARSON, V.; KOIDE, R.; CAIRNEY, J.W.G. Nutrient transport in mycorrhizas: struture, physiology and consequences for the symbiosis. Plant and Soil, v.159, p.103-113, 1994.

SMITH, T.F. The effect of season and crop rotation on the abundance of spores of vesicular-arbuscular (VA) mycorrhizal endophytes. Plant and Soil, v.57, p.475-479. 1980.

SOUZA, F.A.; ALMEIDA, D.L.; SILVA, E.M.R.; GUERRA, J.G.M. Pré-cultivos com espécies vegetais distintas atuam de forma diferenciada sobre o potencial de inóculo de fungos micorrízicos arbusculares (MA) nativos do solo. I. Influência de algumas leguminosas e sorgo sobre o número de propágulos. In: REUNIÃO BRASILEIRA SOBRE MICORRIZAS, V, Florianópolis, SC. 1994. Resumos, Florianópolis: Universidade Federal de Santa Catarina, 1994. p 68.

STEFFAN, R.J.; ATLAS, R.M. DNA amplification to enhance detection of genetically engineered bacteria in environmental samples. Applied and Environmental Microbiology, v.54, p.2185-2191, 1988. 
STEFFAN, R.J.; ATLAS, R.M. Polymerase chain reaction: aplications in enviromental microbiology. Annual Review of Microbiology, v.45, p.137-161, 1991.

TOMMERUP, I.C.; ABBOTT, L.K. Prolonged survival and viability of VA mycorrhizal hyphae after root death. Soil Biology Biochemistry, v.13, p.431-433, 1981.

THOMAS, G.V. Vesicular-arbuscular mycorrhizal symbiosis in coconut (Cocos nucifera) in relation to the root (wilt) disease and intercropping or mixed cropping. Indian Journal of Agricultural Science, v.57, n.2, p.145-147, 1988.

THOMPSON, J.P. Decline of vesicular-arbuscular mycorrhizae in long fallow disorder of field crops and its expression in phosphorous deficiency of sunflower. Australian Journal of Agricultural Research, v.38, p.847-867, 1987.

TRUFEM, S.F.B. Aspectos ecológicos de fungos micorrizicos arbusculares da mata tropical úmida da Ilha do Cardoso, SP, Brasil. Acta Botânica Brasileira, v.4, n.2, p.31-45, 1990.

TRUFEM, S.F.B.; BONONI, V.L. Micorrizas vesículo-arbusculares de culturas introduzidas em áreas de cerrado. Rickia, v.12, p.165-187, 1985.

TRUFEM, S.F.B.; MALATINSZKY, S.M.M.; OTOMO, H.S. Fungos micorrízicos arbusculares em rizosferas de plantas do litoral arenoso do Parque Estadual da Ilha do Cardoso. SP, Brasil. Acta Botânica Brasileira, v.8, n.2, p.219-229, 1994.

VARMA, A. Ecophysiology and aplication of arbuscular mycorrhizal fungi in arid soils. In: VARMA, A. \& HOCK, B. (Ed.) Mycorrhiza. Structure, funtion, molecular biology and biotechnology. Berlin: Springer-Verlag, 1995. p 561-591. 
WANG, G.; WHITTAM, T.S.; BERG, M.; BERG, D.E. RAPD (arbitrary primer) PCR is more sensitivy the multilocus enzymes eletrophoresis for distinguising related bacteria strains. Nucleic acids Research, v.21, p.5930-5935, 1993.

WHITE, T.J.; BRUNS, T.; LEE, S.; TAYLOR, J. Amplification and direct sequencing of fungal ribossomal RNA genes for phylogenetics. In: INNIS, M.A.; GELFAND, D.H.; SNINSKY, J.J.; WHITE, T.J. (Ed.) PCR protocols: a guide to methods and application. New York: Academic Press, 1990, p.315-322.

WILLIAMS, J. G.K.; KUBELIK,A.R.; LIVAK, K.J.; RAFALSKI, J.A. \& TINGEY, S.V. DNA polymorphisms amplified by arbitrary primers are useful as genetic markers. Nucleic Acids Research, v.18, n.22, p.6531-6535, 1990.

WYSS, P.; BONFANTE, P. Amplification of genomic DNA of arbuscular mycorrhizal (AM) fungi by PCR using short arbitrary primers. Mycological Research, v.97, p.1351-1357, 1993.

ZAMBINO, P.J.; SZABO, L.J. Phylogenetic relationships of selected cereal and grass rusts based on rDNA sequence analysis. Mycologia. v.85, p.401-414, 1993.

ZEZE, A.; HOSNY, M.; GIANINAZZI-PEARSON, V.; DULIEU, H. Caracterisation of a highly repeated DNA sequence (SC1) from the arbuscular mycorrhizal fungus Scutellospora castanea and its detection in planta. Applied and environmental Microbiology, v.62, p.2443-2448, 1996. 